





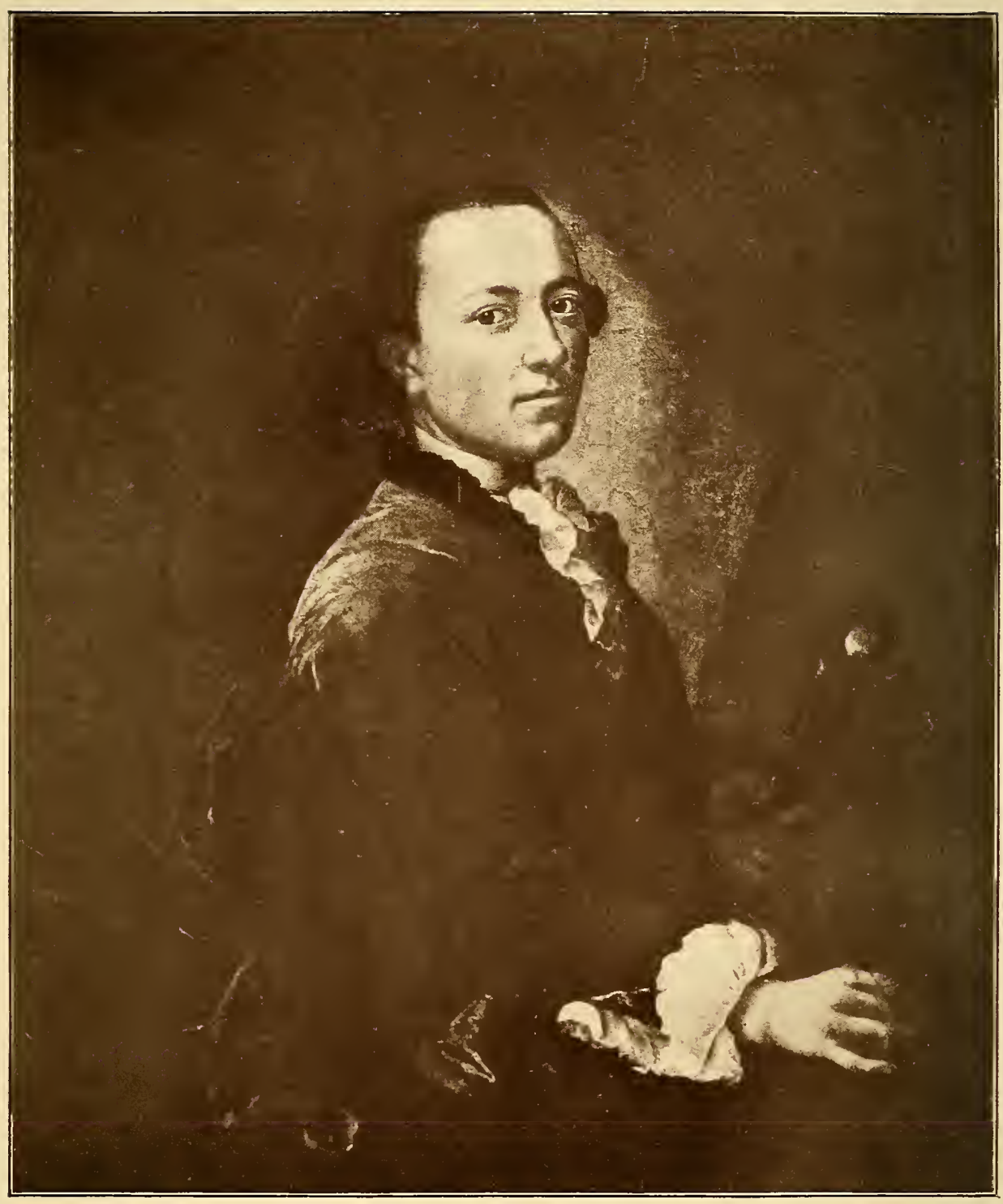

JOHN SINGLETON COPLEY

FROM THE ORIGINAL PAINTING BY COPLEY

IN THE NEW YORK HISTORICAL SOCIETY 


\title{
THE LIFE AND WORKS of JOHN SINGLETON COPLEY
}

\author{
FOUNDED ON THE WORK \\ OF \\ AUGUSTUS THORNDIKE PERKINS
}

\author{
By \\ FRANK W. BAYLEY \\ oF \\ COPLEY GALLERY \\ BOSTON, MASS.
}

BOSTON

THE TAYLOR PRESS

1915 


$$
\begin{aligned}
& 1 \\
& 40.1 \\
& C 78 B 3 \\
& \text { AAPG }
\end{aligned}
$$




\section{Preface}

The author of this memoir is an admirer of the work of John Singleton Copley and has for many years been familiar with his pictures. In the collection of the data, the basis of effort was the admirable work performed by the late Augustus Thorndike Perkins and published privately by him in $\mathrm{I} 873$, and the author freely admits that his compilation of Copley's pictures has only been made possible by Mr. Perkins' efforts. The author desires to acknowledge his indebtedness to Mr. Frederic Amory, Mrs.W. Austin Wadsworth, Mr. Lawrence Park, Mr. Worthington C. Ford, Mr. Harcourt Amory, Mr. Charles Henry Hart, Lord Aberdare, and the many owners of Copley portraits who have allowed him to see them and who have assisted in correctly recording them. 



\section{John Singleton Copley}

John Singleton Copley was the son of Richard Copley of County Limerick, Ireland, and Mary Singleton of County Clare, Ireland, descending from the Lancashire family of that name. Richard and his wife arrived in Boston in 1736 and the future artist was born July 3, 1737, the father dying on a trip to the West Indies soon after John was born. There is no evidence that Copley received any other education than that afforded by the primitive schools of the time supplemented by the family tuition. In 1748, according to the records of Trinity Church, Boston, Mrs. Copley was married to Peter Pelham who was, considering the period, a man of fair education, a passable painter, a good engraver, besides being a surveyor and mathematician. As young Copley was but eleven years old at the time of his mother's marriage to Pelham it is fair to assume that Pelham taught his stepson the rudiments of his art. An engraving of William Welsteed, dated 1753, by Copley indicates that he studied with his stepfather. At the time of his marriage to Mrs. Copley, Peter Pelham was a widower with three sons, Peter, Charles and William. By the second wife he had Henry, 
whose portrait by Copley, known as the "Boy with the Squirrel" has become so familiar. When but fifteen years old Copley painted a portrait of his stepbrother Charles and when sixteen he painted the portrait of Rev. William Welsteed. A portrait of himself as a boy represents a lad of perhaps eighteen with a broken straw hat on as mentioned by "Tuckerman." In 1754 he painted the picture of "Mars, Venus and Vulcan," which is signed and dated. These early and crude examples are of no artistic value and are only to be regarded as the genesis of greater things. It is now known that Copley never painted Washington; the miniature attributed to him is by some other hand and the author of this list has, therefore, omitted it from the compilation. Several pictures enumerated by the compilers of previous lists of Copley's work, better information have shown to be by other painters and have been omitted.

Blackburn and Smybert painted in Boston and if Copley did not receive the benefit of their instruction he saw their pictures. Smybert certainly was no mean artist and brought to this country casts, drawings, prints, and many copies from old masters. Copley was fourteen years of age at the time of Smybert's death in I75 I and he must have derived great benefit from seeing the copies made by Smybert. The lack of early advantages appears chiefly in 
Copley's coloring. The picture of the "Boy and the Squirrel," however, is remarkable for transparency and richness of hue. It is an interesting coincidence that West and Copley were, unknown to each other, studying the rudiments of their art, the one in Pennsylvania and the other in Massachusetts, and both destined to achieve eminent success together.

Mr. Trumbull says that while he was a student at Harvard College he visited Copley, who was dressed on the occasion in a suit of crimson velvet with gold buttons, and the elegance displayed by Copley in his style of living, added to his high repute as an artist, made a permanent impression on Trumbull in favor of the life of an artist.

Copley made rapid progress as a portrait painter and commanded early in his professional career the time and purses of the well-to-do in Boston and New England. It is evidenced not only in the prolific record of his work but by the fact that as early as I768 Charles Wilson Peale sought his instruction and John Trumbull later desired to become a pupil. Copley writes to Thomas Ainslie under date of Boston, February 25, 1765, "I have a large room full of pictures unfinished which would engage me these twelve months."

Copley was elected a Fellow of the Society of Artists of Great Britain, September 3, 1766, according to the following copy of a letter. 
Sir

"I am directed to acquaint you that on the second of September you were elected a Fellow of the Society of Artists of Great Britain. Your attendance is therefore desired at the Turks Head Tavern in Gerrard Street, Soho, on Monday the sixth of Octo next at six o'clock in the evening in order to be regularly admitted.

I am sire your very humble servt

$$
\text { F. M. Newton Secy" }
$$

Sept. 3, 1766

This is interesting as showing the esteem in which Copley was held long before he took up his permanent residence in England.

In 1767 Copley sets forth his feelings in a letter to Captain Bruce, a gentleman who seems to have been an admirer of the works of Copley. "I would gladly exchange my situation for the serene climate of Italy, or even that of England; but what would be the advantage of seeking improvement at such an outlay of time and money. I am now in as good business as the poverty of this place will admit. I make as much as if I were a Raphael or a Correggio; and three hundred guineas a year, my present income, is equal to nine hundred a year in London. With regard to reputation, you are sensible that fame 
cannot be durable where pictures are confined to sitting rooms, and regarded only for the resemblance they bear to their originals. Were I sure of doing as well in Europe as here, I would not hesitate a moment in my choice; but I might in the experiment waste a thousand pounds and two years of my time, and have to return baffled to America. Then I should have to take my mother with me, who is ailing; she does not, however, seem averse to cross the salt water once more; but my failure would oblige me to recross the sea again. My ambition whispers me to run this risk; and I think the time draws nigh that must determine my future fortune." In something of the same strain and nearly at the same time Copley wrote to West. "You will see by the two pictures I have lately sent to your Exhibition, what improvement I may still make, and what encouragement I may reasonably expect. I must beg, however, that you will not suffer your benevolent wishes for my welfare to induce you to think more favourably of my works than they deserve. To give you a further opportunity of judging, I shall send over to your care for the Exhibition the portrait of a gentleman, now nearly finished; the owner will be in London at the same time. If your answer should be in favour of my visit to Europe, I must beg of you to send it as soon as you can, otherwise I must abide 
here another year, when my mother might be so infirm as to be unable to accompany me; and I cannot think of leaving her. Your friendly invitation to your house, and your offer to propose me as a member of the Society, are matters which I shall long remember."

What the answers of Bruce and West were, I have not been able to learn; but it is to be supposed they still left it a matter of uncertainty, whether it would be more profitable to go to London or remain in Boston. Seven years elapsed from this time till he finally set sail for Italy. Copley was busy extending his fame with his pencil, and hoarding his earnings for the outlay of travel and study. He had, as he acknowledged to West, as many commissions in Boston as he could execute. The price for his half lengths was fourteen guineas; he also executed many likenesses in crayons.

In I 769 Copley married Susannah Farnum, daughter of Richard Clarke, a wealthy merchant of Boston, and agent of the East India Company. We constantly meet her familiar lineaments in Copley's works. Mary in "The Nativity," again in "The Family Picture," and in the "Venus and Cupid," or in the female group in "The Death of Major Pierson."

In I77I Copley wrote that he was earning a com- 
fortable income. At this time he moved in the best society, where his courtly manners and genial disposition made him a general favorite. He was now approaching the crucial period of his life. He saw the approaching storm that was soon to break and deluge his country in blood. He was peculiarly situated and in a trying position. It is said that his sympathies were at first with the Revolutionists, and he acted as an intermediary between them and his father-in-law, Richard Clarke, to whom the tea was consigned, but when the infuriated mob destroyed the tea and attacked the warehouse and residence of Mr. Clarke, forcing him to flee for his life, Copley could no longer tolerate mob rule. His case was like that of many others of whom it is said "persecution made half of the king's friends." These outrages occurred in December, 1773. Less than two years afterward he wrote to his wife, from Italy, July, I775: "You know years ago I was right in my opinion that this would be the result of the attempt to tax the colony; it is now my settled conviction that all the power of Great Britain will not reduce them to obedience. Unhappy and miserable people, once the happiest, now the most wretched. How warmly I expostulated with some of the violent 'Sons of Liberty' against their proceedings, they must remember; and with how little judgement, in 
their opinion, did I then seem to speak! But all this is past; the day of tribulation is come, and years of sorrow will not dry the orphan's tears nor stop the widow's lamentations, the ground will be deluged in the blood of its inhabitants before peace will again assume its dominion in that country."

Copley commenced in $\mathbf{1 7 6 9}$ to acquire property on Beacon Hill and gradually added to his holdings.

"In I773," says the late eminent conveyancer, Nathaniel Ingersoll Bowditch, "Copley owned all the land bounded on the west by the Charles River, thence by Beacon Street to Walnut Street, thence by Walnut Street to Mt. Vernon Street, thence by Mt. Vernon Street to Louisburg Square, thence by Louisburg Square to Pinckney Street, thence by Pinckney Street to the water; containing about eleven acres of land."

His stepbrother, Henry Pelham, looked after the property for him during the occupation of Boston by the British and, after the close of the war and the restoration of peace, the big estate at the head of the Common began to be really valuable. Especially did the waste land of the western slope of Beacon Hill become an object of interest to the speculators of that day when it was whispered about that the new state house would be located on the summit of the hill, and near the Beacon monument. 
At the eastern corner of Beacon and Walnut Streets lived Dr. Benjamin Joy, an old Boston practitioner and shrewd man of affairs, who at once saw the value of the Copley tract.

$\mathrm{He}$ enlisted the services of Harrison Gray Otis, a local lawyer, then of much repute, and Jonathan Mason, Jr., to secure the Copley estate, and whatever additional acreage in the vicinity could be obtained. Dr. Joy, after the land had been bought, would take his share.

In some way General William Hull, then a successful lawyer, was brought into the matter, as was also, as an investor, James Swan, a Boston merchant, who resided abroad. It was through the efforts of General Hull that Copley gave a bond for the deed and received as part compensation for his property the sum of one thousand pounds.

Later on, however, when the deed reached London, Copley had heard of the projected new state house and he refused to sign the deed. The artist claimed that neither he nor his agent knew of the contemplated new state house when the bond was executed, otherwise he would not have parted with his property so readily. Legal complications followed, and Copley was forced to comply with the provisions of the original contract and sign away all ownership in the property. He sent his son, John Singleton Copley, 
to Boston with full power to act in all matters that pertained to the affair in hand. On reaching Boston the son wrote the following letter to his father:

$$
\text { "Boston, Jan. 2, I796. }
$$

"I have an opportunity of writing only one half line by a vessel which sails almost immediately, to inform you of my safe arrival in Boston at 4 o'clock this morning, after a tempestuous passage of more than eight weeks. I am this instant going to Gen. Hull, whom I saw this morning. He has written to you upon your affairs at length. Scott has made affidavit that no such verbal transaction as you mentioned ever took place.

"The business cannot come on till May. If you can make yourself a subject of the United States you are clear. If otherwise, I am not yet sufficiently informed to say what may be the result if you are decreed an alien; but take courage. I cannot say more than wish my most affectionate regards to my dear mother and my two amiable sisters, and add that they would be agreeably disappointed at a view of Boston."

The young attorney, afterward famed in England as Baron Lyndhurst, lord high chancellor, found it no easy task to straighten out the tangle into which the affairs of the Copley land investments had fallen, and to show the measure of success he reached in 
the adjustment of all differences, extracts from his own account should be quoted:

"I have, my dear sir," he writes to his father under date of February 27, 1796, "concluded my negotiations with Messrs. Mason, Otis, etc., etc: how you will be affected by the result, whether it will give you dissatisfaction or pleasure, I cannot determine.

"But had your ground been firmer still there was no hope that the business would be settled within the space of two years and a half. After much negotiation, and after various consultations with your counsel and with Mr. Rogers, I acceded, in pursuance to their advice, to the following terms: That you should retain the $£$ Iooo received from Hull and that I should receive on your account an addition of 3000 guineas, deducting the amount of Phillips' mortgage.

"They also indemnify you against Hull, which will cost them, I understand, or rather I know, £2200 more. I do not believe that any person could have obtained from them one shilling more."

Thus the dream of Copley's life after he left America vanished. The "farm" on Boston Common, to which he was so warmly attached, had slipped from his grasp, and his last aspiration of returning to end his life in his native land, among congenial scenes, of course melted away with it. 
He embarked for England in June, I774, six months after his father-in-law was driven out of Boston by the mob and one year before the conflict with the mother country commenced. Leaving his aged mother, his favorite brother, his wife and children behind him, he went to prepare a place of refuge for them from the impending storm. Probably the desire to visit Europe and behold the work of the great masters of the art he loved so well had something to do with leaving his native land, to which he was never to return. After travelling and studying two years on the Continent, he went back to London and was soon joined by his family. Then began a career of uninterrupted success. He became the fashion, and many of the nobility sat to him as did also three of the princesses, daughters of George III. Following the fashion of the day he took up historical painting, which included the Death of Major Pierson and the Death of Chatham, both now in the English National Gallery; the Siege of Gibraltar, now in the Guild Hall of London; and Charles I demanding in the House of Commons the surrender of the five impeached members, which now hangs in the Boston Public Library. "The Death of Major Pierson" in repelling the attack of the French at St. Helier's, Jersey, on the sixth of January, I78I, was painted in 1783 for Alderman Boydell for his 
gallery. The woman flying from the crowd in terror, with the child in her arms, was painted from the nurse of Mr. Copley's family; the figure between her and the wall, with the upraised arm, is Mrs. Copley; the boy running by the nurse's side is young Copley. When his collection was dispersed it was bought back by Copley, and remained in the house in George Street until Lord Lyndhurst's death, when it was purchased for the National Gallery for 1500 guineas.

By this time, 1783 , when we find the King sanctioned his election as an Academician, Copley's reputation had been firmly established by works of great merit in portraiture and historical subjects. Chief among the latter is the "Death of Chatham." The chief excellence of the picture is the accurate delineation of the large number of portrait heads. When this picture was first shown, praise poured in upon the artist. "I delight," said Mather Byles, "in the fame you have acquired." He refused I 500 guineas for the picture and twenty-five hundred engraved copies were sold. In I784 Copley showed the "Youth rescued from a Shark" and the "Death of Major Pierson." During all this period Copley was painting portraits and indeed from this time until a year before his death was his most prolific period.

His last work was the "Resurrection." 
Copley died at his residence in George Street, London, September 9th, I8I5, aged seventy-eight, and was buried in the tomb belonging to Governor Hutchinson's family in the Parish Church at Croyden, near London.

Copley's portraits are among the few memorials of the past in America and they are in the highest degree characteristic of the period in which they were made. It has been said that the possession of one of these ancestral portraits is an American's best title to nobility. Copley was after all the only painter who achieved great skill in the new world prior to the Revolution. To mention any of the many good portraits painted by Copley in this brief introductory sketch of the man himself would only make a duplicate enumeration.

\section{Note}

It is generally agreed that Copley was born in 1737. There is, however, no entry in the Boston Records of his birth. In a letter from Copley to Peter Pelham dated September I2, I766, he writes of being "a bachelor of twenty-eight." This would indicate his birth as being in 1738 . 


\section{New York Portraits}

Until the appearance of the Copley-Pelham letters recently published by the Massachusetts Historical Society, it was the cause of more or less controversy as to whether, before he left the country, Copley painted any portraits outside of New England. The following extracts from Copley's correspondence removes all doubt regarding the authenticity of many New York portraits, as Copley passed seven months painting there.

\section{Captain Stephen Kemble to Copley}

(Before April 17, I77I)

Mr. Copely will inform Captain Kemble if he inclines to come to New York in the Spring, or Summer. If he does, he will specify the time he proposes to stay, and the number of Pecktures he would undertake to draw, and mention his Price for Busts, half Lengths, and whole lengths, of Men, Women, and Children. Capt. Kemble will then send Mr. Copely, the Names of those, who will employ him, that Mr. Copely may be at a Certainty.

\section{Copley to Captain Kemble}

Sir,

$$
\text { (no date) }
$$

Major Goldthwait, communicated to me your memorandum desireing to know the price of ye 
Different sizes of portrait and what number I would undertake to do at New York.

As to the number it will be determined by the time it may be in my power to stay should I go in May toward the end of the Month and sooner it will not be in my power to go and come away in Sepr. I may be able to engage 12 or 15 half Lengths, or in proportion to that, reckoning whole Length as two half Lengths, and half Length Double the busts. More I could not engage without a Longer stay, and I cannot say at present it would be in my power to stay beyond that time, tho this is not quite certain. The price of Whole Lengths 40 Guineas, half Length 20, I/4 pieces of Busts IO. Weither Men or Weomen makes no difference in the price nor does the Dress; but Children in the $1 / 4$ pieces will be more, because of the addition of hands, which there must be when a Child is put in that size; but should the hands be omitted, the picture may be smaller and than the price will be the same as for a Mans or Womans without hands. But if hands they will be something more tho the price will be not exceeding I5. According to maner size of ye Picture you will see by this my price is greater I have set than what I have here. But the Reasons are so obvious why it should be that I think it needless to menshon them. 


\section{Captain Kemble to Copley}

New York, I7th April, I77I.

Sir,

I am sorry a short absence of mine, and a little negligence on the part of some who were desired to procure subscribers to your Terms, has been the means of delaying an Answer to your Letter of the 2oth of March. But I have now the pleasure to acquaint you that twelve $1 / 2$ lengths are subscribed for (two Busts to a half Length) and I make no doubt as many more will be had as your time will permit you to take. I hope this delay in answering your Letter will not prevent your undertaking your Journey to this place. I am Sir Your most Obedient Servant

Steph. Kemble.

\section{List of Subscribers}

(April 17, I771.)

We the undermention'd Persons do promise to have our Pictures drawn by Mr. Copley, agreeable to the Sizes set opposite to our Names.-

Lengths half Lengths Busts

Mrs. Gage

2

I

Mr. Ogilvie

Miss Johnston 
half Lengths Busts

Captain Maturin

I

J. Mallet

I

Mrs. Morris

(Here part of a page is lost)

Captain \& Mrs. Montresor

Mr. Barrow

I

Mr. Sherbrook

I

Mrs. McEvers

Mrs. Mortier

Mr. Hust \& Lady

Mr. Kemp

\section{Notes}

Gabriel Maturin was a captain in the 3Ist Regiment.

Jonathan Mallet was a surgeon in the 46 th Regiment.

The Mrs. Morris mentioned is probably Mrs. Roger Morris. York.

Abraham Mortier was Deputy-Attorney-General.

The Mr. Sherbrook mentioned was probably Miles Sherbrook and the Mr. Montressor was John Montressor. 
Henry Pelham to Henry and Thomas Bromfield

Boston, June 6, r77r.

Gentlemen,

Mr. Copley, before he sat out for New York, desired me to transmit a memorandum of some Articles, which as he is in great want of he requests you would ship by the very first Opertunity. You will oblige him by being perticular as to the Size and Quality of the Glass there being a great Difference in the Thickness and Clearness of the New Castle Crown, some of it being not inferior to the London Crown. You will please to procure the Cloths of the very best kind, the last you sent not being equal in goodness to the price. The inclosed Bill you will pass to his Credit. As my Brother resides all Summer at New York, you will direct the things to me at this place. I am Gentlemen your most Obedient, Humble Sert.

Henry Pelham

\section{Copley to Henry Pelham}

\section{Dear Harry,}

New York, 16 of June, I77I.

We are now fixed in a very comodious House in this City. We arrived here on Thursday night and our Journey perfectly agreable, and has contributed a great deal to my looks. * * * I come now to 
say somthing of this place, but really I have not been yet able to attend to anything but that of getting myself a little settled, that I may go to Business, and I beleave you will think I have done pretty well to be ready to begin Mrs. Gages portrait tomorow, which I propose to do, considering I have had but friday and Saturday to Deliver several Letters and get sutiable Lodging. * * * I am your Affectionate Brother

J. S. Copley.

\section{Copley to Henry Pelham}

New York, June 20, I77I.

Dear Harry,

I must not omit so good an oppertunity as the present to let you know we are well, and that painting much engages the attention of people in this City and takes up all my time. I have begun three portraits already, and shall as soon as time permits fill my Room which is a very large one. * * *

John Singleton Copley.

\section{Henry Pelham to Copley}

Boston, July I I, I77I.

Dear Brother,

By Capn. P. Smith you will I hope receive in good order your Layman, Crayons and Drawings and Major Bayard's Picture. The Crayons and gold 
Button holes are packed in the same Box with the Layman, the Drawings and Paper underneath Major Bayards Picture. ***

Henry Pelham.

\section{Copley to Henry Pelham.}

$$
\text { New York, July I4, I77I. }
$$

Dear Brother,

This Eveng I devote with pleasure to you as I know it must give you pleasure to be inform'd of every surcumstance attending our situation here I will give you a minute detail and of the maner in which Sukey and myself spend our time. But to begin with the most important. Sukey and myself are very well; she is employed in working on muslin, and myself in the Labours of the pencil. We commonly rise by six o'Clock in the morng, breakfast at 8 , go to our respective Labours till 3, when we dine; at six ride out, and since we have been here I have by no accident Lost more than one Day, as there is so many that are impatient to sit $\mathrm{I}$ am never at a loss to fill up all my time. My large Chamber is about 9 feet high and 20 feet long and near as broad, with a good room adjoining it, the light near north. I have begun $4 \mathrm{I} / 2$ lengths $6 \mathrm{I} / 4$ peaces I Kitcat. When we came here Capt. Richards's portrait (at Mr. Sherbrooks) was so much admired that vast numbers went to see it. Mr. McEvers 
(from whom by the way we have received great civility) spoke to Mr. Sherbrook to send it to my Chamber where it is as much esteemed as I Could wish. As I am visited by vast numbers of People of the first Rank, who have seen Europe and are admirers of the Art, I was glad to have a Picture so well finish'd. Most of them say it is the best Picture they ever saw and all agree in its being an admirable Picture. I saw a miniature the other Day of Governor Martin by Miers which cost 30 Guineas and I think it worth the Money. * * *

J. S. Copley.

Copley to Henry Pelham

Dear Brother,

New York, the 20 of Sepr. I77I.

Your favour by Capt. Smith I received yesterday and shall answer paragraph by paragraph. The frames came safe to hand and I hope will do, but shall know better when they have been seen by those who will want frames, and soon as possable if they will answer you shall have my orders. ***

Your Effectionate Brother John S. Copley.

Henry Pelham to Copley

Dear Brother,

Boston, Septmr. 24, I77I.

* * The Frame and Glass, I should have sent had I not forgot it till after Smith Sailed. At 
Bottom is the Receipt for Varnish. I have received Money from Messers. Sargent, Fenno, Barrell, Goldthwait, Pepperell, Hancock and Mrs. Watts. I have about $90 £$ O. T. by me. Mr. Jno. Green owes, as also Mr. Flucker, Mr. Loring and Mrs. Martin. These I wait your directions before I apply for the Money. * * *

Henry Pelham.

\section{Copley to Henry Pelham}

New York, the 29 of Sepr., I77I.

Dear Brother,

We have just arrived at this place after a very pleasant Journey. Philadelphia, We thought a place of too much importance not to Visit when we were so near it, and perhaps might never be able to see it so conveniently if we missed this opportunity. we sett out last Thursday week, the Weather very fine, and reach'd the City on Saturday Eveng. I have seen several fine Pictures with which you would have been Charmed had You been with us. at Mr. Allen's (to whom General Gage was so obligeing as to give me a letter) We saw a fine Coppy of the Titiano Venus, an Holy Family at whole Length as large as life from Coregio, and four other small half Lengths of Single figures as large as life, one a St. Cecelia, an Herodias with John Baptists head, Venus lamenting over the Body of Adonus and I think a Niobe I cannot be 
certain. The Venus and Holy Family I will give some account of, the others I will leave till I can give it you by word of mouth. The Venus is fine in Colouring, I think beyand any Picture I have seen, and the Joints of the Knees, Elbows, etc., very Read, and no Gray tints anywhere to be found. the hair remarkably Yellow and I think the face much inferior to any other part of the figure in releiff and Colouring. there is no minuteness in the finishing; everything is bold and easey; but I must observe had I Performed that Picture I should have been happrehensive the figures in the Background were too Strong. The Holy Family is not Equil to the Venus in Colouring; it suffers much by the Comparison, tho I do not think it indeferent in that part neither, but might be pronounced fine in Colouring was not the Venus compaired with it. But what delights us in this picture is that universal finishing and harmoniseing of all parts of it. I have made a slight sketch of it which will give you a better Idea of the Disposition when you see it than any thing I can say, * * *

\section{Copley to Henry Pelham}

New York, the I5 Decr., I77I.

Dear Brother,

I take this oppertunity of informing you, I have sent by Capt. Smith (who sails this Day) $5 \mathrm{I}$ Trees of the Best fruit this Country affoards, also some wild 
Laurell is in earth in a Barrell. also 3 Barrels of Newtown Pippens, and as many for Mr. Clarke which I beg you to inform him of, as I dont write to him by this oppertunity. and one trunk Directed to Mr. Jonathan Clarke. Likewise the Large Box with the large Frames which I have not been able to Dispose of. your favour per Mr. Glover came to hand. we are happy to hear you are all well, and that at last I can inform you this Week finishes all my Business, no less than 37 Busts; so the weather permitting by Chrismass we hope to be on the road: but you must not expect our journey will be less than a fortnight at this season, as we propose to take so much care of ourselves, and which we may well do, as the Country is surprisingly settled between Boston and York. you scarcely lose sight of an house. you may omit writing any more as we cannot expect to meet another Letter here wrote after this reaches you.

Give our Effectionate Duty to our Hond Mama and xcept our sincere Love yourself. I am your most Effectionate Brother

John Singleton Copley. 



\title{
Pictures Exhibited by Copley at the
} Royal Academy 1776-1812

\author{
Living at Leicester Fields, London
}

I776 62 A Conversation Elected A. R. A.

I777 6I A Family-Whole Length

62 Portrait of a Gentleman-Whole Length

63 Portrait of a Gentleman-Three-Quarters

64 The Nativity

177863 A Family - Whole Length

64 Portrait of a Lady-Three-Quarters

65 A Boy attacked by a Shark Elected R. A. in $\mathbf{1 7 7 9}$

I780 97 Portrait of a Lady

I72 Portrait of a Highland Officer (Major Montgomery)

I95 Portrait of a Gentleman

2 I I Portrait of a Naval Officer

I783 5 Portrait of a Nobleman (Lord Mansfield)

227 Portraits of two young Gentlemen

Living at George Street, Hanover Seuare I785 80 Their Royal Highnesses Princess Mary, Princess Sophia, and Princess Amelia, Daughters of George III 
I786 230 Portrait of a Lady-Half Length

423 Portrait of a Young Lady and her three Brothers

I793 75 The Red Cross Knight, Fidelia and Speranza (See Spencer's "F a e ri e Queen" Book I, Canto Io) (Master and Miss Copley)

I796 46 Abraham offering up Isaac

9I Portrait of a Gentleman

287 Portrait of a Gentleman (John Adams)

I798 73 Portrait of J. A. Graham, Esq., LL.D.

IOI Portrait of the Speaker of the House (Henry Addington)

IO7 An historical Picture representing

"Hagar and Ishmael in the Wilderness"

I I I Portrait of Viscount Duncan

235 An historical Picture representing Saul reproved by Samuel

I800 24 Portrait of Earl Spencer

72 Portrait of Lady Dudley and Ward

I08 Portrait of Viscount Dudley and Ward

556 Portrait of R. Wilson, Esq.

I80I 2I Portrait of the late Colonel Fitch and the Misses Fitch

I63 Portrait of R. Richards, Esq., of Lincoln's Inn

I803 70 Portrait of the Earl of Northampton 
I804 2I Portrait of Baron Graham

3 I Portrait of Mrs. Montague, the wife of Rear-Admiral Montague, and her Brother

96 Portrait of Viscount Dudley and Ward

I84 St. Cecilia, a Portrait

I805 I 83 Portrait of Mr. Cawthorne

I808 I The offer of the Crown toLady Jane Grey by the Dukes of Northumberland and Suffolk

I46 Portrait of Rev. John Codman of Boston, New England

I 809 20I Portrait of Lord Sidmouth

58 Portraits of H. R. H. the Prince of Wales at a Review attended by Lord Heathfield, General Turner, Col. Bloomfield and Baron Eben; Colonel Quinton in the distance

I8I2 I88 The Resurrection

\section{Note}

Copley sent no pictures to London for Exhibition in I 769-I 770 or during I773 or I774. Copley exhibited 8 pictures at the Society of Artists of Great Britain, 43 at the Royal Academy and 8 at the British Institute. 


\section{Lyndhurst Sale}

THE FOLLOWING PICTURES INHERITED OR PURCHASED BY JOHN SINGLETON COPLEY (BARON LYNDHURST) WERE SOLD AT AUCTION IN LONDON, MARCH 5, I864

Portrait of Lord Howe (Small Circle)

54 Portrait of Admiral Barrington (Small Circle)

$56 \quad$ Portrait of Admiral Duncan (rolled)

$57 \quad 38$ G. Portrait of Lord Heathfield

$58 £ 8$-10 Portrait of an Officer

$59 £_{10-10}$ Cupid caressing Venus

6054 G. Portrait of a Lady, dated Boston 1772

6I £I I-I I A Youth rescued from a Shark

62 £Io-Io The Nativity

$63 £ 12-13$ Charles I. etc. (Sketch)

$648 \mathrm{I} / 2 \mathrm{G}$. Monmouth before James II refusing to give the names of his accomplices

$65 £ 46-16$ Sketch for "The Siege of Gibraltar"

$66 £$ £o-10 Portraits of Colonels Hugo and Scheoppengull

$67 £$ £Io-Io Portrait of Major-General De La Motte

$68 £$ £10-Io Portrait of Colonel Duchenhausen

$69 £$ £II-II Portrait Head of a favorite Negro

$704 \frac{1}{2}$ G. First Sketch for "The Death of the Earl of Chatham" 
7I $£$ I-I First Sketch for "Death of Major Pierson"

795 5 $1 / 2$ G. Early Sketch for "Charles I. demanding the Arrest of the Five Members"

$73 £_{21}$ Portrait Head of an American Lady

74 £ro Portrait of One of the Misses Copley in a Hat

$75 £ 26-5$ Portrait of the Artist

$76 £ 9-17$ Portrait of Mr. Bransden

$77 \quad 24$ G. Abraham's Sacrifice

$78 \quad 32 \mathrm{G}$. Hagah and Ishmael

79245 G. Sketch for "Children of George III"

$80 £$ £ro5 Samuel and Eli

8I 230 G. Portrait of Lord Mansfield seated

82 5I G. St. Jerome after Correggio

8324 G. The Virgin and Child

$84 £ 27 \quad$ Saul reproved by Samuel

$85230 \mathrm{G}$. The Boy with the Squirrel

$8670 \mathrm{G}$. The Red Cross Knight

$8751 / 2$ G. Battle of the Pyrenees

$88 £ £_{5}$ George IV. as Prince of Wales

8922 G. Offer of the Crown to Lady Jane Grey

$90 \quad$ I600 G. The Death of Major Pierson

9I I000 G. Portraits of John Singleton Copley and Family

\section{Notes}

55 Exhibited at Royal Academy in $\mathbf{1 7 9 8}$ 
57 This is a study for one of the portraits in the "Siege of Gibraltar"

60 This is the portrait of Mrs. Skinner in the Boston Art Museum

6I In the Boston Museum of Fine Arts

63 Sketch for the Picture in the Boston Public Library

65 Sketch for the Picture in the Guildhall

66 Studies for the same Picture

67 Studies for the same Picture

68 Studies for the same Picture

69 Studies for "The Boy and the Shark"

72 Sketch for the Picture in the Boston Public Library

74 Sarah Clark, afterwards Mrs. Charles Startin

77 Exhibited at the Royal Academy in I798

79 Sketch owned by R. T. Paine, 2d. Original in Buckingham Palace. Exhibited at the Royal Academy in 1785

80 Engraved for Macklin's Bible

85 Picture belongs to Mr. Frederic Amory of Boston

86 Picture belongs to Mr. Gordon Dexter of Boston

87 Picture belongs to Mrs. F. Gordon Dexter of Boston

88 Picture belongs to Mrs. F. Gordon Dexter

9I The well known "Family Picture" in the Boston Museum of Fine Arts 


\section{The Following List of Pictures}

WHILE FAIRLY COMPLETE, DOES NOT CONTAIN ALL, AND YeT THE AUTHOR FEELS CONFIDENT A LARGE MAJORITY OF COPLEY'S WORK IS HERE RECORDED

\section{Sir Robert Abercromby}

Sir Robert Abercromby was born in October 1740, near Sterling, Scotland, and died on the third of November, 1827 . He was a British soldier and served in Canada through the French war, and as colonel of a regiment during the War of the Revolution. The expedition that destroyed American shipping in the Delaware was led by him, and in May, I778, he surprised General Lacey at Crooked Billet. He was wounded at Monmouth and led a sortie from Yorktown, capturing two batteries. In $\mathbf{1} 790$ he was made Major-General, served in India, succeeded Cornwallis as Commander-in-chief in 1793, and was promoted to General in I800. The portrait is an unusually fine example of Copley's work. It shows Sir Robert posed against a shadowy dark green background and looking directly out of the canvas. He wears a rich brown velvet coat with white lace at throat and wrist, and a touch of red indicates a brilliant colored waistcoat. The face is full with features 
admirably modeled, and from a broad forehead the hair is combed back and powdered. The canvas measures about twenty-four by twenty-nine inches.

\section{Abraham's SaCrifice}

This picture was shown at the Royal Academy in 1796. Engraved by Dunkarton and sold in the Lyndhurst sale.

$$
\text { John Adams }
$$

This portrait of Washington's immediate successor is full length, painted in London in $\mathrm{I} 783$ and exhibited at the Royal Academy in 1796. He is attired in a brown velvet court dress, standing by a table, underneath which is a globe. This portrait was presented to Harvard College by W. N. Boylston and is now in Memorial Hall. The following is a copy of the bill for the portrait.

London Decr. IO, I783 Recd. of John Adams Esquire, one hundred Guineas in full for his portrait.

$$
\text { J. S. Copley }
$$

\section{John Adams}

This is the portrait of a distinguished merchant, the son of Rev. Hugh Adams, his wife being Susannah Parker. The picture is half length, life size, and 
represents him as dressed in a brown coat, a richly embroidered satin waistcoat, and a full wig. He stands with his right hand resting on his hip, while his left is thrust into his waistcoat. It has a background with the sea and ships in the distance. It belongs to Mr. George B. Dorr of Boston.

\section{Mrs. John Adams}

This portrait of the wife of John Adams, the eminent merchant of Boston, is a companion picture to that of her husband. Her left hand lies in an easy position while her right is concealed by her dress. She is dressed in a blue robe, cut low in the neck, and her hair is dark. The background is a landscape. It belongs to Mr. George B. Dorr of Boston.

\section{John Quincy Adams}

This beautiful portrait was painted while $\mathrm{Mr}$. Adams was United States Minister at the Hague in I795. It was presented by the artist to Mr. and Mrs. John Adams. A fine example of Copley's work at his best period. It hangs in the Boston Art Museum being lent by Mrs. Robert Homans.

\section{Samuel Adams}

This picture is of three-quarters length. $\mathrm{He}$ is standing by a table, holding a paper in his hand. 
The dress is a brown coat. It is a very spirited and fine example of Copley's work and was painted for John Hancock and hung for nearly fifty years in the Hancock House before it became the property of the City of Boston. Governor Samuel Adams was born in Boston in 1722 in Belcher's Lane, now Purchase Street. He graduated from Harvard University in I 740 and was elected representative to the Assembly in I 765. He married Elizabeth, daughter of the Rev. Samuel Checkley, in 1749. In 1775 he was proscribed by the British Government. In I78I he was president of the Massachusetts Senate; was chosen Lieutenant-Governor in 1789, and was Governor from I794 to I797. His enthusiastic support of the Revolution was surpassed by none. Samuel Adams died in 1803 . This portrait was painted in 1771 , belongs to the City of Boston and now hangs in the Boston Art Museum. A second picture of Mr. Adams, in Copley's latest style, is in the possession of Harvard College. It is a smaller picture measuring twelve by sixteen inches.

\section{Thomas Ainslie}

Collector of the port of Quebec and a captain in the city's militia. His diary during the operations against Quebec in $1775-1776$ was printed by the Library and Historical Society of Quebec. In a letter 
to Copley from Ainslie, dated Quebec, November I2, 1764, this picture is mentioned, and also under date of October 8, I 757 Ainslie mentions sending the portrait to Glascow, Scotland.

\section{Mrs. Ethan Allen}

This is a portrait of Frances Montesque, daughter of Col. Monte and Margaret Schoolcraft Montesque. She is represented as a child of nine. Her first husband was Captain Buchannan of the British Army, who was killed less than a year after their marriage. In 1784 she married General Ethan Allen, and in 1792 she married Dr. Jabez Penniman of Colchester, Vt.

The whereabouts of this portrait is unknown.

\section{James Allen}

Was born in 1739 , and was quite distinguished as a poet. He wrote the well known lines on "The Boston Massacre," and many other pieces. It was thought by those conversant in the matter, that had he not been a man of large fortune and easy disposition, he would have risen to great eminence. He died in 1808. This picture, which is in the possession of the Massachusetts Historical Society, is of half length, 
and represents a young man with dark eyes and hair, dressed in a brown coat and waistcoat with gold buttons, and a black silk neckerchief.

\section{Nathaniel Allen}

Was a grandson of Joseph Allen, who came to Gloucester in 1674. This portrait is of three-fourths length. He is dressed in a brown suit of the times, and is seated at a table, his left arm resting on a book, and holding a letter in his hand. The whole picture is beautifully painted. It is in the possession of Charles S. Sargent of Brookline.

\section{Mrs. Nathaniel Allen}

Her maiden name was Sarah, daughter of Colonel Epes Sargent. She is represented as standing, and wearing a large hat. She is dressed in a steel-colored silk, and is drawing on her glove. It is three-fourths length, and in Copley's late manner. It is in the possession of Charles S. Sargent of Brookline.

\section{John Amory, Senior}

A merchant, and a son of Thomas Amory; born August 29, I728, died June 5, I803. He married January 16, I757, Katherine Greene, daughter of Rufus Greene, who was a great-grandson of John 
Greene who came to New England from Salisbury, England, in 1638 . This portrait is of three-fourths length. The subject is standing with one hand resting on the back of a chair, the right hand holding an open letter. The color of the picture is now of a subdued richness and represents the dress as being a goldlaced brown velvet coat, and small clothes. Beyond are drapery, sky, the sea, and a ship. It is in the possession of his descendant, Miss Martha Codman, Washington, D. C. The following bill for the portrait is in the possession of his descendant:

\section{Boston, 1768}

Mr. John Amory to John Singleton Copley, Dr. To his own portrait, half length $£_{14-0-0}$ Nov. 24, 1769. Paid as per receipt book.

Mrs. Katherine Greene Amory

Wife of John Amory, a daughter of Rufus and Katherine Greene. She was born in 1720 , and died April II, I777, in London. This picture is chiefly composed of browns and yellows, the dress being yellow silk or satin. The drawing of one of the hands is poor. In a strong light may be seen a little negro boy beneath a table. The picture is in the possession of Mr. George A. Goddard of Boston. 
Thomas Amory

Was born in 1682, and married Rebecca Holmes May 9, I72I. He died June 20, I728. This portrait is drawn in colored crayons, only giving the head and shoulders and must be a copy by Copley of another portrait by some other artist, which was probably destroyed by fire in the house of his son, Thomas, in 1787. The features are full and rather regular, with a beautifully fresh and light complexion. The dress is a greenish-blue robe, with a full, curling wig. It is in the possession of his descendant, Miss M. P. Codman, Bristol, R. I.

\section{Thomas Amory}

Was born in 1722 , died in 1784 . This portrait is in oil, of three-fourths length. He is dressed in a brown coat, and leans upon a staff, holding a glove in his hand. It belongs to Mr. Ingersoll Amory, of Boston, and is now in the Boston Museum of Fine Arts.

John Andrews

A prominent merchant of Boston and selectman in I785. He was an intimate friend and correspondent of John Elliot. Some of his letters have been published by the Massachusetts Historical Society. This 
is a crayon drawing, one-quarter length, representing the subject when he was twenty-eight years of age, and is in a fine state of preservation. It was in the possession of his son, the Rev. George B. Andrews, Highwood.

\section{Rev. Nathaniel Appleton}

Was born in 1693 , died in 1784 . He is dressed in clerical robes and bands, and is represented as sitting in a chair, and holding a book in his hand. This picture was painted in 1764 and is in the possession of Harvard College.

\section{Mrs. Nathaniel Appleton}

Wife of Rev. Nathaniel Appleton, whose maiden name was Margaret Gibbs, was born in I70I and died in I77I. The dress is a black basque with a skirt of gray silk. The right elbow rests upon a table with the hand supporting the face. It is a half length picture, and is in the possession of Harvard College.

\section{Captain Apthorp}

An officer of the British Navy. This is a crayon of half size. It was in the possession of Miss Ann Apthorp, Jamaica Plain. 
Rev. East Apthorp

Rector of the Episcopal Church in Cambridge. He was the son of Charles Apthorp, merchant of Boston. After his admission to holy orders he returned to this country from England, where he was educated. After a career of six years here in the ministry he again went to England, where he died in 1816 at the age of eighty-four years. This portrait was in the possession of a Miss Dexter, of Philadelphia, Penna.

\section{Mrs. John Apthorp}

Was Hannah, daughter of Sheriff Stephen Greenleaf and Mary Greenleaf, his wife. She was married

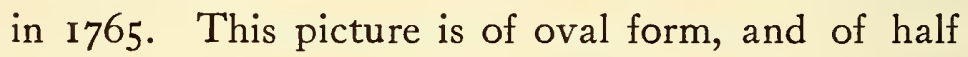
length, representing a young lady dressed in a blue silk, edged round the neck with white lace. She has also a pink scarf, fastened at the waist by a pearl pin. The face is rather in profile. Round her neck she has a collar of three rows of pearls, tied behind with a blue bow. Her dark hair, without powder, is drawn back from her face, and dressed with pearls, and with three small flowers on the top. The portrait was in the possession of Mr. R. E. Apthorp, of Boston.

\section{The Ascension of Christ}

Copley made a drawing of this subject while he was in Rome in 1774 and later a painting in England. 
The painting is in the possession of Mrs. F. Gordon Dexter.

\section{Judge Theodore Atrinson}

Judge Atkinson was born at Newcastle, N. H., December 20, 1697 and died Sept. 22, I 779. He was Secretary of the Colony in I74I Chief-Justice in 1754 and Maj.-Gen. of Militia in I769. The Revolution deprived him of all these offices. At his death he left $\$ 200$ to the Episcopal Church of Portsmouth, N. H.

\section{Mrs. Theodore Atkinson}

She was Hannah, daughter of Governor John Wentworth. This portrait belonged to Mr. Asa Freeman of Dover, N. H., and later to Mr. Louis Popham, Scarsdale, Westchester County, New York.

\section{Aurora}

Copley made a copy in water color of Guido's Aurora in 1775 while at Parma, Italy. Its whereabouts is not known.

\section{Mary Smith Austin}

Born December 19, I7IO. Died in her 9oth year at Concord, N. H., February 9th, I800. She was an aunt of Abagail Smith Adams and she married Ebenezer Kent, 1 Jr., November Ioth, I757, and the portrait 
has come by descent to the present owner, Prentiss $M$. Kent, of Boston. It is of three-fourths length, the figure being seated in a large green chair holding a book. Her dress is of brown satin with cap, fichue, and under sleeves lace-trimmed. The picture was rescued from the walls of her house at the burning of Charlestown by the British in $\mathbf{1 7 7 5}$.

\section{AdAm BABCOCK}

The son of Dr. Joshua Babcock of Westerly, R. I. This portrait is of a young man nearly full length without wig, seated, with hand partly resting on a table and holding a pencil. In the other hand he holds a writing tablet. The whereabouts of this portrait is unknown to the author. Adam Babcock was a distinguished merchant of Boston.

\section{Mrs. AdAm Babcock}

This is a fine example of Copley's work. The figure is seated, face slightly turned. She wears a head dress or turban of lace and pearls and her dress is of light silk; a dark cloak lined with ermine completes her costume. The whereabouts of this picture is unknown. 


\section{Mrs. John Bacon}

The wife of the Rev. John Bacon, of the Old South Church. This lady was the daughter of Mr. Ezekiel Goldthwaite, of Boston, was born in 1733, and married for her first husband the Rev. Alexander Cummings. The costume is of brown satin, the sleeves ruffled at the elbows, and a lace shawl; over the neck is a pearl necklace. A small cap completes the whole costume. This picture is remarkable for the brilliancy given to the eye and the beauty of the hand and arm. She died in Stockbridge in I821. This portrait, painted in 1769 , is two and one-half feet square, and together with the original bill for it, is in the possession of a descendant, Miss Fannie E. Colt of Pittsfield, Mass. Following is the bill for her portrait and two others.

Boston Mrs. Elizabeth Cummings to Jn. S. Copley, Dr.

I769 To her own portrait $3 / 4$ lgth. at 7

Guis.

To Mrs. Maquarter's Do.

To Mr. Maquarter's Do.

1770 To two Black Frames at 24/

Recd. the contents in full

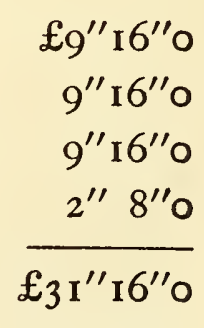

John Singleton Copley

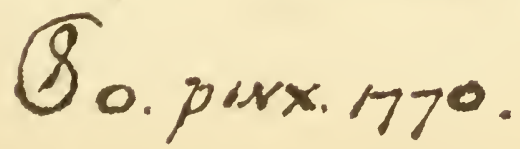


Mrs. BACON

The mother of Judge Bacon. This picture was painted in $177 \mathrm{r}$, and when last heard of was in Utica, New York. Its present owner is unknown.

Mrs. Eunice Balston

A daughter of John Turner, of Salem. She married first, in I729, Colonel Benjamin Browne, and second, Mr. Balston. The picture is five feet long by three and a half wide. The portrait is in the dress of the period, and is a fine specimen of Copley's manner. It belongs to Mr. Edward N. Fenno.

\section{Wilkes Barber}

This portrait of a young man is referred to in the following letter to Nathaniel Barber.

Princes Court, near Stories Gate, Westminster, Sept. 21, I770.

Sir,

My Brother Hayley has sent me from you a most Valuable present of a Picture which I receive with great Gratitude and pleasure from its being the recemblance of my dear namesake, and the merit of the Work it self. I was very happy to Observe to 
what a degree of excellence the most elegant art of Painting is Arrived in New England, and as you rival us in every essential good, so you now equal us in the refinements of Polished Life. I shall expect every thing good and intrinsically valuable from the Young Gentleman, whose Picture I admire, when I consider that he is educated under your care, and among the generous sons of Freedom in America, who remain undebauch'd by the wickedness of European Courts, and Parliamentary Prostitution. I pray heaven to give you great Comfort in him, and to permit him long to enjoy the Benefit of the virtuous example you set him! My most respectfull compliments ever attend the friend(s) of Liberty at Boston, and I beg you, Sir, to beli(e)ve me, with great truth and regard, Your Obliged, humble Servant

John Wilkes.

Barber had a son Wilkes Barber, and sent to Wilkes a portrait of the child, then in his fourth year by Copley.

Rev. Edward Barnard

An early portrait of this gentleman in his clerical robes in the possession of the Essex Institute at Salem. He was minister of the Church at Haverhill, Mass., and died in 1774 . 


\section{Joseph BARRELL}

A crayon portrait, companion in size to that of his second wife. The subject is represented in a flowered silk gown, broad plain collar, lace at neck. Mr. Barrell has dark brown hair and his head is half turned. He holds his gown together in front with his left hand which only partly shows. This picture is owned by Henry F. Barrell of New Providence, N. J. Joseph Barrell was a prominent merchant of Boston, born in 1740. He married for his first wife Anna Pierce and secondly Hannah, daughter of Timothy and Abigail Fitch. Mr. Barrell's house was situated in Charlestown, Mass., on the site afterwards occupied by the McLean Hospital.

There is a miniature portrait of Mr. Barrell set in gold as a bracelet measuring an inch and a quarter by an inch and a third and is exquisitely painted. The whereabouts is unknown.

\section{Mrs. Anna Pierce Barrell}

This is a very handsome crayon portrait of the first wife of Joseph Barrell, formerly of Charlestown, Mass. It measures seventeen by twenty-three inches. The lady died at twenty-three years of age. This picture was for many years owned by Mrs. J. W. Terry, the youngest daughter of Mrs. Electra Barrell 
Wilder, to whom it descended from her grandfather, Joseph Barrell. The flesh tints are pure and warm, hair dark brown, eyes greenish blue, large and clear regular features. The upper part has been damaged and nearly obliterated. The hair is dressed high with a bunch of flowers and a string of pearls twisted among them. The bodice is a greenish blue satin and is caught by a dull gold brooch in the centre. The sleeves are looped up by a gold cord. Over one shoulder is drooped a peach blossom colored shawl. This picture was shown in the Burlington Magazine of May, 1907, and was exhibited during the HudsonFulton Exhibition at the Metropolitan Art Museum. It is owned by Mrs. William Allen Putnam of Brooklyn, N. Y.

Another beautiful pastel portrait of this lady by Copley of the same size as the before-mentioned picture is owned by Miss Dorothea Keep and was also shown at the Metropolitan Art Museum during the Hudson-Fulton celebration. She has her hair dressed high and wears a pink rose in her corsage.

\section{Mrs. Hannah Fitch Barrell}

This is one of Copley's most beautiful portraits. It is in pastel and perfectly preserved. She was the daughter of Timothy and Abigail Fitch, and the mother of Mrs. Benjamin Joy. The picture measures 
nineteen by twenty-four inches. Mrs. Barrell was the second wife of Joseph Barrell of Charlestown, and in the picture is shown dressed in a bodice of blue satin and an overdress of pink silk trimmed with ermine. In her bosom she wears a rosebud. Her hair is combed back from her face and dressed with a cluster of short curls. Her eyes are hazel and lips pouting. It belongs to Mrs. C. H. Joy of Boston.

\section{Colburn Barrell}

There is an authentic record that Copley painted a portrait of this gentleman, who was a prominent loyalist. It belonged at one time to the Rev. Mr. Andrews of Highwood, but its whereabouts is not known. Colburn Barrell was the son of John Barrell and Ruth Greene Barrell. He was born in 1735 and married Ann Rymes.

\section{JoHN BARRETT}

A full length picture, forty by fifty inches. He is represented as seated beside a table; his right hand holds a pen and his left rests upon his knee. $\mathrm{He}$ is dressed in a suit of olive-colored cloth. Mr. Barrett was a distinguished merchant of his time. He was born June I2, I708. He was one of the warmest friends and most active supporters of the cause of liberty, in behalf of which he gave most liberally 
from his own private means. As an instance of this, he chose to redeem with gold, to a large amount, the paper money paid to our troops in Boston by the government. He was one of the committee of six, appointed by the merchants of Boston, in 1768 , to resist the imposition by Parliament upon the Colonies of the onerous duties on sundry articles of commerce. The committee of six were Thomas Cushing, John Hancock, William Phillips, John Barrett, John Erving, Jr., and Edward Payne. On their recommendation the merchants of Boston pledged themselves not to send for nor import from Great Britain, between January I, I769, and January I, I770, any kind of goods except those absolutely necessary; the same being named in an agreement. Mr. Barrett was for many years deacon of Dr. Eliot's church, in Boston, and died September 9, I786. This picture belongs to the estate of Mrs. S. D. Barrett.

\section{Mrs. John Barrett}

Was Sarah, daughter of John Gerrish, born July 25, I7I I, married Mr. Barrett, June 3, I73 I, and died February 8, I798. In her will Mrs. Barrett mentions the portrait of her husband and herself, painted by Copley. Her picture is fifty by forty inches, representing her as wearing a robe of olive brown bro- 
caded damask, with a dark green cloak ornamented with scarlet. The dress is cut square in the neck, over which is thrown a muslin kerchief; embroidered muslin sleeves, a muslin cap and a pearl necklace complete the costume. This picture belongs to the estate of Mrs. S. D. Barrett.

\section{Judge Samuel Barrett, LL.D.}

The son of John and Sarah Barrett, was born in Boston in 1738, graduated at Harvard College in 1757. He married first, Mary, a daughter of Richard Clarke, and sister to Susan Clarke, who married Copley. Their brother was Richard Clarke, Jr., some time Commissary-General of the British Army in Boston. His second wife was Elizabeth Salisbury. He was Judge of Probate, and also a Judge of the Supreme Court, and received the degree of LL. D. from the University of Edinburgh. Judge Barrett is represented as dressed in a white wig, and the costume of the times. The picture is oval, and in Copley's latest manner, having been painted in London, and is now owned by Edward Temple of Windsor, Vermont.

\section{Mrs. Samuel Barrett}

Who was Mary Clarke, a daughter of Richard Clarke, and the sister of Mrs. Copley. The portrait 
is a small oval, five and one-half by four and one-half inches, on copper, and represents a pretty young woman in a hat of those times. It is in the possession of Miss Mary E. Cabot of Brookline.

\section{Admiral Barrington}

Samuel Barrington, born 1729 , died 1800 , entered the British Navy at sixteen and had continuous service for nearly fifty years. A mezzotint engraving was made by Sharp of this portrait which was published by Copley in I8Io. It was sold at the Lyndhurst sale in London in 1864.

\section{Battle of Trafalgar}

There is good evidence that Copley planned and began this picture but it was never completed.

\section{Battle of the Pyrenees}

This is a very large and grand work, unfinished, sold at the Lyndhurst sale in $\mathbf{1 8 6 4}$ for five and a half guineas. In it are portraits of the Duke of Wellington, the Prince of Orange, and Lord Marsh. It is now in the house of Mrs. F. Gordon Dexter of Boston.

\section{Benjamin Beale}

He was born in England, May 30, I74I, and died at Quincy, Mass., January 29, I825. He was by pro- 
fession a sea captain, and is represented in a full dress suit of light cloth. The size is twenty-nine by twentyfour inches. This portrait was in the possession of his grandchildren, the Misses Beale, of Quincy, Mass.

\section{Mrs. Benjamin Beale}

Whose maiden name was Ann Copeland, was born in Liverpool, May 27, 1745; married there in 1767 , and died in Quincy, February I3, I8I4. This portrait was in the possession of her grandchildren, the Misses Beale, of Quincy, Mass.

\section{Beale}

There is a small portrait of the son of Mr. and Mrs. Benjamin Beale, size thirteen by fifteen inches. $\mathrm{He}$ was born in Liverpool, June 6, I768; died in 1826 , in the Bourbonais, Province of Normandy, France, where he resided the greater part of his life. This portrait was also in the possession of the Misses Beale, of Quincy, Mass.

\section{Sir George Beaumont}

Sir George Howland Beaumont was born in 1753 and died in I827. An art patron and amateur painter. He was intimate with Dr. Johnson Copley Reynolds, Scott Wordsworth and Coleridge; presented several pictures to the National Gallery. 
A portrait of this gentlemen, measuring twentyfive by thirty inches, was sold in New York in February, 1906.

\section{BELCHER}

There are said to be portraits of the Belchers in the possession of the Jennison family.

\section{Sir Edward Berry, K.C.B.}

This fine portrait of Rear-Admiral Berry is in Greenwich Hospital, London.

Sir Edward Berry was born I768; died I83I. He served under Nelson in nearly all the important naval engagements, including the Battle of the Nile and Trafalgar.

\section{LORD BEsBorough}

This picture is in England but its exact whereabouts is unknown to the author.

\section{Mrs. BLACK}

Of half size. Represents a young lady in a white satin robe. This picture was given by Mrs. Black to Mrs. Boardman, and by her to her daughter, Mrs. Harrison Gray Otis, in whose possession it was in 1872 . 


\section{Joseph BLAKe}

This is a small portrait on copper, beautifully painted. It is the work of the artist at nineteen. The subject is dressed in the uniform of the French and Indian War, blue coat with gold buttons, red waistcoat and laced hat. The picture belongs to his great-grandson, Rear-Admiral Charles H. Davis of Washington, D. C.

\section{Mrs. Blaney}

She was a daughter of Mrs. Browne, who married Colonel Epes Sargent for her second husband. The portrait is forty by fifty inches in size and is companion to that of her mother. She is shown standing, three-quarters length. Her dress is of cream color satin, corsage low and lace-trimmed. Her right arm is resting on a pilaster with the left hand by her side. Her hair is dressed high with bead ornaments. There is a landscape panel on the wall at her left. The portrait now belongs to Mr. George N. Black of Boston.

\section{Mrs. Sylvanus Bourne}

Whose maiden name was Mercy Gorham. It is stated in Freeman's History of Cape Cod, Vol. II., page 30I, that a portrait of this lady was painted by 
Copley. When last heard of, it was in the possession of Colonel Samuel Swett of Boston. Its whereabouts is now unknown.

\section{JoHN BOURS}

Portrait of a gentleman dressed in a handsome costume of brown velvet with lace at neck and sleeves. $\mathrm{He}$ is seated in a three-legged mahogany chair with right hand holding a book and head resting on the other hand. It has a landscape background. It is in its original carved frame. Mr. Bours was a resident of Newport, R. I., much interested in affairs of the Episcopal Church and a lay preacher in Trinity Church. It is now in the Worcester Art Museum.

\section{JABEZ Bowen}

He was the son of Dr. Ephraim Bowen, a prominent physician and patriot prior to the Revolution. Jabez Bowen died in 1815 . The portrait represents him as a young man. He was a graduate of Yale University and returned to Providence, where he became a chancellor of Brown University for thirty years. A lawyer by profession, he was at one time Chief-Justice of the Rhode Island Supreme Court, a member of the Council of War, delegate to the Continental Congress, and Deputy-Governor during the Revolutionary period. $\mathrm{He}$ was a member of the 
Society of the Cincinnati. He entertained at his residence in Market Square, Providence, Washington, Lafayette, and Rochambeau. His grave is in the family lot at Swan Point and has a "Revolutionary Marker" as have those of his two brothers, Dr. William Bowen and Dr. Pardon Bowen. A third brother, Col. Eph. Bowen, was of the party that destroyed the "Gaspee" and is buried in St. John Churchyard, Providence. The portrait belongs to Mr. Henry Bowen of Providence, R. I.

\section{Mrs. Jabez Bowen}

This portrait is companion to that of her husband. She was Sarah, daughter of Obadiah Brown of Providence, and was married December 19, I762. This portrait belongs to Mr. Henry Bowen of Providence.

\section{James Bowdoin}

Governor of Massachusetts, was the son of James Bowdoin, a member of the Council, who died in $\mathbf{1 7 4 7}$, and a grandson of Pierre Bowdoin, who emigrated in I68 5 from La Rochelle. Governor Bowdoin was born in 1726 . He graduated from Harvard College in I745, and died in I790. His ability and wealth made him one of the distinguished men of his times. His residence was at the corner of what is now Tremont 
Row and Howard Street. He was a Representative three years, Member of the Council sixteen years, and Governor two years, and displayed great executive ability, especially during Shay's Rebellion. He married Elizabeth, Daughter of John Erving. He had one son, James, who married his cousin, Sarah Bowdoin, and one daughter, Elizabeth, who married Sir John Temple, Bart. The eldest daughter of Lady Temple married Hon. Thomas Lindall Winthrop. The picture at present belongs to Mrs. Robert C. Winthrop. This portrait is an oval miniature, face in profile with white wig and dark coat. It was probably painted about $\mathbf{I} 770$.

A small picture of Governor Bowdoin, about seven by ten inches, representing him as standing in his library, is also owned by Mrs. R. C. Winthrop of Boston.

\section{Mrs. Mary Bowers}

A daughter of Joseph Sherburne of Boston. This picture is four-feet six inches in length, by three-feet nine inches in width. It was taken at the age of twenty-six years. Her dress is of white satin, with a train of purple velvet edged with gold. She has a Blenheim spaniel in her lap. It was in the possession of her granddaughter, Miss Mary Danforth of Boston. 


\section{Judge Metcalf Bowler}

In the possession of Mrs. William C. Snow, Providence, R. I.

Mrs. Judge Bowler

Wife of Judge Metcalf Bowler, of Providence, R. I. The size of this picture is forty by fifty inches. Mrs. Bowler is represented as dressed in a blue satin robe, the sleeves of which are trimmed with lace. On her head she wears a Marie Stuart cap, and she has a sapphire necklace about the throat. In her hands she holds a garland of flowers. The picture was in the possession of her granddaughter, Mrs. Robert Bowler of Covington, Kentucky.

\section{Nicholas Boylston (Three Pictures)}

The first is a full length, and represents him as dressed in a blue morning robe and purple cap.

The second, dated 1767 , with a monogram, is of three-fourths length, in a green morning robe, with ships in the distance. He was born in 1716, or 1717 , and died in I77I. He was one of the benefactors of Harvard College, and founded a Professorship of Rhetoric and Oratory, of which John Quincy Adams 
was the first professor. These pictures are in the possession of Harvard College.

A third picture of this gentleman represents him as seated, and dressed in a morning robe and cap. It is of three-fourths length, and is in the possession of David P. Kimball of Boston.

\section{Thomas Boylston}

This picture is of three-fourths length. The dress is a morning robe with a white satin waistcoat. $\mathrm{He}$ holds a pen in his right hand, and the left rests upon the back of a chair. It is at Harvard College.

\section{Mrs. Thomas Boylston}

Is painted of three-fourths length, sitting in a chair, with her hands crossed upon her lap. Her dress is of gray satin, and upon her head is a white cap. In the background there hangs a curtain. Mrs. Boylston died February 1774. This picture is in the possession of Harvard College and was presented by N. W. Boylston.

\section{General William Brattle}

Was born in 1702, graduated at Harvard College in $\mathbf{1 7 2 2}$, and died in $\mathbf{1 7 7 6 .}$ He is represented in full uniform as a Major-General. The picture is signed "John Singleton Copley, 1756," Copley being at that 
time under twenty years of age. It belongs to the estate of Marjorie C. Appleton and is now in the Boston Museum of Fine Arts.

Richard Brocklesby, M.D., F.R.S.

This is a half length, standing portrait, of the celebrated physician. A mezzotint engraving was made by Readley in 1798. Dr. Brocklesby was born in 1722 and died in I797. He enjoyed the intimate friendship of Burke and Dr. Johnson and attended the latter in his last illness.

\section{JoHN BROWN}

This is a comparatively early example of Copley's work. The subject is shown at life size and full length in a seated position. He is dressed in a brown coat elaborately embroidered. There are four buttons on the sleeves which also show lace. His right hand is partially concealed in his waistcoat and the left hand rests at the side. He has a white wig and there is a letter with seal resting on a table. John Brown was prominent in the affairs of Boston during the Revolutionary period and was Selectman of Boston in 1776 . The portrait belongs to Mrs. A. A. Pray of Boston. 


\section{Mrs. Mary Barron Brown}

Was born in Charlestown, August 20, 1726; married Captain Stephen Brown in $\mathbf{1 7 4 6}$, and died December 22, I80I. The picture measures thirty-five by fortyone inches. Mrs. Brown is represented as a very handsome woman of dark complexion with black hair and black eyes. She holds a flower in her right hand. She is sitting with her hands lying in her lap, a lawn handkerchief crosses her neck, the ends passing under a band of velvet. Her dress is of dark blue velvet, beautifully painted, with sleeves of velvet and white lawn with ruffles. The background shows glimpses of sky and water and a large tree. This fine example of Copley's work is now owned by Mr. R. M. Pratt of Boston.

\section{Captain Stephen Brown}

The size of this picture is about forty-nine by thirty-five inches. It represents a very handsome man of large stature, rich brown complexion, and large black eyes. He has black hair brushed off from the forehead and temples, raised a little in the middle, and arranged in small bunches at the ears in the style of a wig. He is attired in a single-breasted, dark brown coat, with a very narrow collar, and narrow black cravat encircles his throat; a little of the shirt 
just appears where the waistcoat is open at the top. He wears a very long dark green velvet waistcoat, trimmed with narrow gilt braid. The sleeves of the coat reach about three-fourths of the length of the arms, with buttons on the tops of the cuffs; a small portion of the shirt sleeves are seen below, fastened with gold sleeve buttons. The right hand is holding the coat away, and rests on the hip. The left hand hangs by his side in an easy position. In the right of the picture is a tree. The background is of dark olive green, and in the left, an island with a few trees upon it, and beyond, the sea and a ship. Stephen Brown and Mary Barron were married at Charlestown by the Rev. Hull Abbott, November 26, 1746. He was a native of Ipswich Hamlet, now Hamilton, and the son of one of the earliest settlers there, but resided in Charlestown before and after his marriage. He died in Edenton, N. C., at the age of thirty-two. The portrait belongs to R. M. Pratt of Boston.

\section{Rev. Arthur Browne}

A half length life size portrait, representing a clergyman of the Church of England in his black silk robes and bands. He was born in England, and was a missionary to this country, and the first rector of St. John's Church, Portsmouth. His pastorate con- 
tinued for thirty-seven years. He was distinguished for his learning and piety, and his fine countenance shows him to have been a man of powerful intellect. It is in the General Theological Library, Boston.

\section{Mrs. Arthur Browne}

Wife of Rev. Arthur Browne. A companion picture to that of her husband, representing a lady dressed in a blue silk robe, and wearing over her shoulders a mantle of a reddish tinge. This picture was in the possession of Mrs. Charles Burroughs, Portsmouth, N. H.

\section{Anne Gardiner Browne}

The Honorable Mrs. Arthur Browne was born in Boston in I74I, and married Hon. Arthur Browne, second son of the Earl of Altamont, a captain in the British Army. She was Anne, daughter of Dr. Sylvester Gardiner, and was a celebrated beauty of her time. She is represented as wearing a white satin dress ornamented with pearls, holding in her left hand a pink satin mantle; the right hand gracefully extended; a landscape is on the right; her hair is not powdered, and a curl hangs over the left shoulder. This picture was painted in England. It belongs to Mr. Robert H. Gardiner of Gardiner, Maine. 
Another of the same subject was in the possession of her grandson, the Marquis of Sligo.

\section{R. G. Bruce}

Copley painted a portrait of his intimate friend and correspondent, Captain R. G. Bruce. It is now in England.

\section{John Burguyn}

Emigrated to America in the eighteenth century, and brought with him a considerable fortune. His residence was Wilmington, North Carolina, where he owned a very large landed estate and from whence he carried on an extensive commercial business, having agents in London, Bristol, Hamburg, and Amsterdam. He was president of the King's Council for the State of North Carolina, a man of great influence and of high character. His portrait was taken in England in $\mathbf{1 7 8 3}$, and is signed in full by the artist. In his diary he mentioned that he paid his friend Copley eighty-three guineas for it. The portrait is of half length, and Mr. Burguyn is represented as standing, holding in one hand a book and in the other a pen; the coat is of dark drab color, and on the head is a white wig. This picture is in the possession of a grandson, Colonel Henry R. Burguyn of Richmond, Virginia. 
Colonel Thaddeus Burr

Of Topsfield, Conn. A picture of two-thirds length. He was a distinguished gentleman of his times. As the last sitting was taken just before a dinner with John Hancock, we have a representation of the dress appropriate to such an occasion, which consists of a brown suit, a blue satin waistcoat with silver buttons, and with ruffles at the neck and wrists. It belongs to Mrs. H. S. Knapp of New York.

\section{Mrs. Thaddeus Burr}

Wife of Colonel Thaddeus Burr, was a Miss Eunice Dennie, of Boston. Like the portrait of her husband it is of two-thirds length; the dress being pink damask, open in front, showing a petticoat of white satin, trimmed with silver lace. There is white lace on the sleeves and at the neck. It belongs to Mrs. H. S. Knapp of New York.

\section{Dr. Mather Byles}

Born in Boston, March I5, I707. He was descended on his mother's side from Richard Mather and John Cotton. He graduated from Harvard College in 1725 and was ordained minister of the Hollis Street Church in I733, where he officiated for fortythree years. He was a Tory and was dismissed from the Hollis Street Church in $\mathbf{1 7 7 6 . ~ H e ~ d i e d ~ i n ~ B o s t o n , ~}$ 
July 5, 1788. This portrait of Dr. Byles is a comparatively early example of Copley's work. The size is twenty by twenty-four inches, and it is in the original black frame. It belongs to Mr. F. L. Gay of Brookline.

There is a much later portrait of Dr. Byles, painted in 1774, at sixty-eight years of age. In this picture he wears a red seal ring, made very prominent. It is owned by Dr. Bruce Almon of Hollis Street, Halifax.

\section{Mather Byles, Jr.}

A companion picture to that of his father. The junior Mather Byles graduated from Harvard College in $175 \mathrm{I}$, and for fifteen years was minister of a church in New London; he went to England and took orders in the Church of England, and on his return here was chosen rector of Christ Church, Boston. In 1776, when the British troops evacuated Boston, he went to Halifax and was made chaplain to the garrison. He was later the rector of a church in St. John, N. B., where he died in 1814 at the age of eighty.

\section{George Cabot}

A small pastel drawing is in the house formerly occupied at Brookline by Colonel Henry Lee. It represents the subject at the age of sixteen years. George Cabot was born in Salem, December 3, I751. 
He left Harvard College in his second year and went to sea. He became master of a vessel. He was a member of the Provincial Congress in 1776, of the

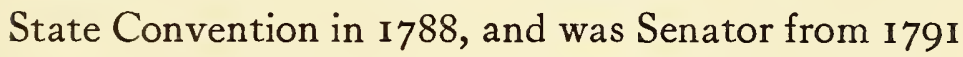
to 1796 . He was the first Secretary of the Navy, from May 3 to May 21, 1798. He was elected to the Massachusetts Council in 1808 and chosen president of the Hartford Convention in 1814. He died in Boston, April 18, 1823 .

\section{Mrs. Joseph Calif}

Was a daughter of Dominicus Jordan of Scarboro. She was born in I70I and died in 1772 . The picture is of life size and nearly full length, and represents her as dressed in a dead-leaf colored satin, the bodice, waist, and sleeves of which are trimmed with deep falls of rich lace. On her head is a lace cap and in one hand she holds a book. It is signed and dated 1765, and was in the possession of Charles E. Miller, Milton.

\section{LORD CAMPERdown}

The portrait of Viscount Duncan, afterwards created Lord Camperdown, was exhibited in the Royal Academy in I798. It was sold at the Lyndhurst sale together with a second portrait. 


\section{Mrs. Carr}

This is a fine example of Copley's late English work. It is a portrait of a beautiful woman, her hair dressed high and falling over the right shoulder. She is in a seated position, the figure shown at half length with hands crossed in her lap. It is in the Liechtenstein Gallery, Vienna.

\section{Mrs. William Carson}

A letter from William Carson, to Copley dated Newport, August 16, 1772, speaks of a portrait as follows: "The longer I look, the better I am pleased. I discover new beauties every day, and what was considered as blemishes, now raises the most exalted ideas of the perfection of the painter and painting to the life. Mrs. Carson's picture, which is by much the most natural and just painting $I$ have seen of yours, only shows what you are capable of executing." The whereabouts of this portrait is unknown.

\section{Samuel Cary}

An oval miniature on ivory. It belongs to Miss Hester Cunningham and is a fine example of Copley's miniature work.

Mrs. Samuel Cary

She was Sarah Gray. It is a companion picture to that of her husband; both are very beautifully painted. It belongs to Miss Hester Cunningham. 


\section{Rev. Thomas Cary}

This picture is of life size. The dress is a flowered robe. The style of the hair is plain, and is cut short. The scene is a library, and the figure is seated, with the hands crossed on an open Bible. Mr. Cary was a clergyman, and was born at Charlestown, October 7, 1745. He was ordained at Newburyport, May I I, I768 and died there November 24, I808. He was the son of Samuel Cary and Margaret Graves. The picture belongs to Miss E. F. Cary of Cambridge.

\section{Miss Catten}

The size of this picture is three-fourths length. The lady is dressed in a rich blue silk, cut square at the throat. She is sitting, with her hand resting on a table. This picture was in the possession of $\mathrm{Mr}$. Hayden of Boston.

\section{Mr. Cawthorne}

A portrait of this gentleman was exhibited at the Royal Academy in $\mathbf{1} 805$.

\section{Peter Chardon}

A colored crayon of half length. He is dressed in the gown, bands, and wig of an English lawyer. Peter Chardon was born in Boston, and came from one of the Huguenot families, driven from France by 
the revocation of the Edict of Nantes. This picture was owned by Edward Brooks, Boston.

\section{Death of Chatham}

This celebrated picture is in the National Portrait Gallery. It contains forty-five different portraits, and was engraved by Bartolozzi. Twenty-five hundred copies were published and sold. The first sketch of this picture was sold at the Lyndhurst sale and is now owned by Mrs. F. Gordon Dexter, and a second finished sketch was at one time shown in the Boston Art Museum. There was also another sketch owned by Lyman H. Tasker of Greenwood, Mass.

A highly finished study in oil of the heads for the picture belongs to Mr. Copley Amory.

\section{Charles Stuart, King of England}

This large picture of the king demanding the Surrender of the five Members, commenced in 1785 , and completed in I79I. There are fifty-eight likenesses all taken from contemporary portraits. It was purchased by a number of Boston admirers of Copley for fifteen hundred pounds, and now hangs in the Trustees' Room of the Boston Public Library. Two sketches for this picture were sold at the Lyndhurst sale, one of which, highly finished is owned by Lord Aberdare, Eaton Square, London. 


\section{Mrs. Miriam (Kilby) Clark}

This picture is of life size. She is sitting in a large chair. Her hair is black and the eyes and complexion dark. She seems to be between fifty and sixty years of age. Her dress is of brown satin, with sleeves to the elbow, and ornamented with ruffles. She wears a simple muslin Quaker cap on her head, and a muslin half handkerchief on her neck. The dress is open in front. She was born about 1700 and married Mr. Benjamin Clark. The picture is in Copley's early manner and is in the possession of Mrs. Andrew C. Wheelwright, and lent to the Boston Museum of Fine Arts.

\section{Dr. John Clarke}

This picture is of three-fourths length. The subject is dressed in black velvet, with a white wig and stockings, and sits by a table on which stands the manikin. He was a distinguished physician of large fortune and great benevolence, practicing principally for his own satisfaction, and thence was known in Boston as "The poor man's physician." The portrait was in the possession of his great-grandson, Peter Wainwright, but was burned in the great Boston fire of 1872 . 


\section{Mrs. John Clarke}

She was Elizabeth Braeme. A companion picture to his. She is dressed in green silk, with pearl ornaments on the neck and hair. The right hand rests on a table, while the left holds a book. Her hair is dressed without powder. The portrait was in the possession of her great-grandson, Peter Wainwright, but was burned in the Boston fire of 1872 .

\section{William Clarke}

Son of Dr. John Clarke. The picture is of threefourths length. He is dressed in a rich pearl-colored suit, handsomely laced, with a white wig. He holds his left hand on his hip, and there are a cottage and trees in the distance. Mr. William Clarke was a man of fortune, having no profession. The portrait was in the possession of his great nephew, Peter Wainwright, but was burned in the fire at Boston in 1872 .

\section{Richard Clarke}

Was a distinguished merchant of Boston. $\mathrm{He}$ graduated at Harvard College in 1729. A determined loyalist, he was an addressor of Hutchinson and Gage, and was proscribed and banished. To him was consigned the tea which was destroyed in Boston by the celebrated tea party. His sons were Richard and Isaac; and his daughters were Susan, 
who married John Singleton Copley, Mary, who married Judge Samuel Barrett, Sarah, who married Mr. Startin, and Hannah, who married Colonel Henry Bromfield of Harvard, Mass. His portrait, which is admirably painted, is in the Family Picture, and represents him as a man of commanding presence.

\section{William Cleland}

A miniature of this gentleman is in the Boston Museum of Fine Arts, the gift of Miss Hannah E. Austin.

\section{John Codman}

Who was married to Abigail Ashbury, nee Soley. This picture is grave in color. The subject is in a sitting posture. The dress is a plain buttoned coat, and he wears white stockings and a white wig. The background is a curtain, a column, and some sky, the blue of which is echoed by the color of the stuff that covers the chair, the only yellow in the picture being the brass nails in the chair. The left hand is remarkably wrell drawn, even for Copley. The right hand is thrust into the breast of the coat. The picture belongs to Miss M. C. Codman,' Washington, D. C.

There is a fine portrait of this gentleman, who was the father of Rev. John Codman, painted in Tor- 
quay, England and in Copley's latest manner. It formerly belonged to Capt. John Codman and is now in England in the possession of Capt. Codman's granddaughter, to go ultimately to the Massachusetts Historical Society, according to Capt. Codman's will.

\section{Rev. John Codman}

He was born January I7, I755, and died May I7, I803. He was the son of John and Abigail Codman, and married Margaret Russell, July I5, 1781. A portrait of this gentleman, who was pastor of the White Church, was exhibited at the Royal Academy in $\mathbf{1 8 0 8}$, and is now owned by Bishop Robert Codman of Portland, Maine.

\section{Richard Codman}

This picture is of life size and the figure is seated. It is of three-fourths length. The great point of merit in the picture is the drawing of the hands, which are holding a letter very naturally and gracefully. The subject of this portrait was born in Charlestown, Mass., in 1762 , graduated at Harvard College in 1782 , and died unmarried in 1807 . The picture was painted about 1790 while Mr. Codman was in England. He passed a great part of his life in France, where he made the beautiful collection of foreign pictures now in the possession of his family. The 
portrait is now owned by his great nephew, Richard Codman, West Roxbury, Mass.

\section{Thomas Aston Coffin}

Represented as a child of five years of age. He was born in Boston in 1754, graduated at Harvard College in $\mathbf{1 7 7 2}$, and died in London in $\mathbf{1} 8 \mathrm{IO}$. He was the Assistant-Commissary to the British Army, with Brook Watson, under Sir Guy Carleton, and continued with Sir Guy after he became Lord Dorchester. He was finally promoted to be Commissary-General of the British Army. He left one daughter, the wife of Dr. Edward Hutchinson Robbins, of Boston. He is dressed in a low necked sacque of green satin, over a dress of white satin, richly embroidered with lace, and with ruffles at the wrists. In his plump and pretty right hand he holds two cherries, while on his left are two white turtle doves. The plumes of his hat are seen behind the left hand. On the floor are battledores and shuttlecocks, and in the background is a pond and trees. The portrait belongs to Miss Nancy Craig Wharton of Boston.

\section{Mrs. Coffin}

This picture is of half length. The dress is cut square, with a lace berthe ornamented in front with three bows. The color of the dress is steel gray. 
The hair and eyes are dark and on the head is a frilled cap. Around her neck are three rows of pearls. The portrait belongs to W. D. Sohier of Boston.

\section{Lord Colchester}

Charles Abbot, First Baron Colchester, was born I757 and died I829. This portrait is in England.

\section{A Conversation}

The first picture exhibited by Copley in $\mathbf{I} 776$ was a picture by the above title.

\section{Myles Cooper, D.D.}

There are two portraits at Columbia University, one of which is probably a replica. In a letter to Copley from Cooper, dated New York, August 5, r 768 , Cooper mentions sending the price of the portrait, viz., 7 guineas and his Gown-Hood and Band in order that Copley might finish the drapery. A copy of it is in the New York Historical Society. He was born in England in 1735 , and graduated from Oxford in $\mathbf{1 7 6 0 .}$ In $\mathrm{I} 762$ he was sent to America as assistant to the Rev. William Johnson, second President of Kings College, now Columbia College. In I763, on the resignation of President Johnson, he became his successor. He visited England I77I to I774, and after his return became such an outspoken loyalist that he was obliged to flee on an English war vessel. He died in Scotland, May I, I 785. 
Rev. Samuel Cooper, D.D.

Born in 1725. Graduated at Harvard College in I743 and was pastor of Brattle Street Church at the age of twenty. He was first vice-president of the American Academy of Arts and Sciences and was an intimate friend and correspondent of Franklin. Copley painted several pictures of this distinguished divine. One very fine one of half length, with wig and bands, is in the possession of Justice Oliver Wendell Holmes.

Two other portraits were in the possession of the Rev. Dr. Lothrop, pastor of Brattle Street Church, the finer one, belonging to the Doctor himself, the other probably a copy.

Another portrait is in the possession of the Massachusetts Historical Society.

There was a crayon likeness of Dr. Cooper in the possession of his grandson, Mr. Hixon of New York City, and another, possibly by Copley, in Memorial Hall, Harvard College.

There is a portrait in Copley's best American manner, representing the subject in his clerical robes, with white wig, and face slightly turned. The picture is of half length, measuring twenty-five by thirty inches, and is in the possession of Mrs. Martin Taylor of Worcester. 


\section{Miss Cooper}

A pastel portrait of the daughter of the Rev. Samuel Cooper is in the possession of Mrs. Taylor of Worcester.

\section{John Singleton Copley}

A life size head, painted by himself, with a powdered wig, and wearing a red coat. It is in the possession of Mrs. G. G. Hammond of Boston.

There is another, a crayon, twenty-three inches by seventeen. In this he wears a pale green coat, lined with blue, a brown embroidered waistcoat, and a lace cravat, with his hair powdered. It is owned by Harcourt Amory of Boston.

A small oval portrait of Copley, painted in England is owned by Mrs. F. Gordon Dexter of Boston.

A beautiful miniature of Copley by himself is owned by Henry Copley Greene and lent to the Boston Museum of Fine Arts.

There is a portrait of Copley by himself in the New York Historical Society. $\mathrm{He}$ is dressed in red, with lace at the neck, face turned toward the front, and is represented as engaged at his easel. He holds a pallette and brushes in his left hand and a brush in his right hand. It is a very fine example. 


\section{Mrs. Copley}

She was Susan, daughter of Richard Clarke, and is represented in this picture as wearing a low-necked blue dress. Her hair is drawn back over a cushion, and decorated with flowers. This picture now belongs to Harcourt Amory of Boston.

There is a small oval pastel portrait of Mrs. Susannah Copley, the wife of the artist, in the possession of Mrs. F. Gordon Dexter.

There is also a study in sepia of Mrs. Copley and her two children for the family picture. It was in the possession of John Singleton Copley Greene, who had also several other studies and beautiful drawings now destroyed.

\section{Susannah Copley}

Child of Copley who died at nine years of age. It was painted shortly before her death. The subject is shown with a large hat which casts a shadow over the brow. The picture is in an oval frame. A photograph of the picture is at the Boston Museum of Fine Arts. It is in England. There is a sketch of this picture in this country.

\section{Cornwallis}

There is a fine half length standing portrait of Charles, Marquis Cornwallis, painted in 1805 . He is 
dressed in full uniform, his left hand holding his glove and resting on a rock, his right hand holding a cane. A landscape background is seen beyond a huge rock, used as a background. It is in the Guildhall, London.

Another portrait of Cornwallis is a picture twentyfive by thirty inches. He is dressed in the uniform of a British General. It is owned by Peter C. Brooks of Boston.

Copley also made a miniature of Cornwallis, according to Williamson's History of Miniatures.

\section{Madam Cotron}

Madam Cotton was a resident of Sandwich, Mass. There was a portrait of her husband, but its whereabouts are unknown. She wears a greenish blue silk dress, loose sleeves, neck cut square, and a rosette on her head. She is seated in a chair with fan in her hand, and there is a column at the left of the picture. The size is forty by fifty inches, and it is owned by $\mathrm{H}$. J. Hayden of New York. This portrait belonged to the Rev. Abraham Williams of Sandwich, Mass., and is supposed to have been given to him by Madam Cotton. It has always been in the family of $\mathrm{Mr}$. Williams, who was Mr. Hayden's great grandfather.

Hon. Thomas Cranston

He was grandson of Governor Saul Cranston of Rhode Island, and served in the General Assembly 
of Rhode Island before the Revolution. The picture is three-quarters length, the figure standing with right hand resting on his hip and left on the back of a chair. He wears a white waistcoat. The portrait is owned by W. U. Hidden of Providence, R. I.

\section{Mrs. Thomas Cranston}

The portrait of this handsome woman, who was Mary Coggeshall, is one of Copley's best. It possesses all the charm of grace and delicacy characteristic of his finest examples. She is dressed in a violet color silk, with a lace kerchief over the shoulders, sleeves lace-trimmed and lace cap, two white satin bows on the front of her corsage, and a double row of pearls encircles her neck. It is three-quarters length and life size, and belongs to Mr. D. Berkeley Updike of Boston.

\section{Miss Rhoda Cranston}

A portrait of a beautifully dressed lady, of threequarter length. Her robe is of pink silk and she holds a spray of flowers. The picture has a landscape background. It is owned by Mr. D. Berkeley Updike of Boston. Miss Cranston became the wife of Rev. Luke Babcock.

\section{Candace Crawford}

In regard to this picture, Mr. Allen says: "All the knowledge I have of the ancient portrait of Candace 
Crawford was obtained from her sister, Mrs. Thorpe, and her daughter, Mrs. Henry Smith. They told me more than sixty-five years ago that it was one of the earliest paintings of Mr. Copley, the celebrated artist. The date of the portrait was not stated to me. Miss Crawford was born in 1746 ; and the likeness represents a maiden of about twenty years, wearing a tasteful flounced blue silk dress, and a purple rose in her bosom. On the supposition that the age of the lady was twenty, this would allow the date of the picture to be about I766. The work is done in good taste, both in the style of drapery and drawing." The picture was in the possession of Zachariah Allen of Providence, R. I.

\section{Cupid Caressing Venus}

This picture was sold at the Lyndhurst sale in London in I864, and is now owned by Mrs. F. Gordon Dexter. The two portraits are those of Mrs. Copley and the infant Lord Lyndhurst. Mrs. Copley as Venus has pale golden hair, bound with blue.

\section{Susanna Griggs Dalton}

This portrait of the first wife of Peter Roe Dalton is a charming example of Copley's middle American period. It measures about thirty by forty inches and is half length, life size, and shows the lady as standing. 
She is represented in short sleeves with lace at the elbow and also an edging for the otherwise plain dress. Her hair is brushed back from her forehead and she holds in both hands a basket of grapes. There is a landscape background. Susanna Griggs Dalton had four children, three of whom died young. This portrait belongs to George N. Black of Boston.

\section{Rev. Edmund Dana}

Was born at Cambridge in I739, graduated at Harvard College in I759. He was Vicar of Wroxeter, Salop, and married the Hon. Helen, daughter of Charles, sixth Lord Kinnaird. This picture is of full length, and is beautifully colored. The subject is dressed in a crimson velvet morning gown, with white small clothes, stockings, and wears a dark velvet cap. This picture was unfortunately destroyed about $\mathrm{I} 840$.

\section{RichaRd Dana}

The father of Chief-Justice Francis Dana. The size of this picture is four-feet two inches in length by three-feet two inches in width. Mr. Dana is dressed in the wig, bands, and black robe of a barrister of the eighteenth century. He was born in Cambridge, Mass., August 7, 1699; graduated at Harvard College in I7 8 ; married a sister of Edward Trowbridge; and died in Boston, May 17, I772. He 
took a prominent part in the movements which preceded the Revolution. He it was who in the presence of a great assemblage of angry towns people, standing under the Liberty Tree, administered the oath to Secretary Oliver, that he had not distributed and would not distribute the odious stamps, nor enforce the hateful act of the British Parliament. This fine picture is in the possession of Richard Dana of Cambridge.

Copley painted a duplicate which is in the possession of the descendants of Mr. Dana in England, and is said to be the better of the two.

\section{Judge Danforth}

It is a matter of record that a portrait in miniature on copper of this eminent jurist was left by the will of Miss Elizabeth Sherburne Blowers Danforth of Boston.

\section{Mrs. Anstice Davis}

Was a daughter of Sheriff Stephen Greenleaf, and a sister of Mrs. John Apthorp. This portrait represents her as a young and beautiful woman. It is excellent both as respects drawing and coloring, and was in the possession of a relative, Mrs. S. G. Bul-

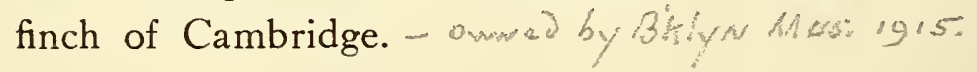




\section{Mrs. Mehitable May Dawes}

The portrait of this lady, who was the daughter of Samuel May of Boston, measures about twenty-five by thirty inches and is not completely finished. She is represented with a large hat very high in the crown with a large bow of ribbon on the front and ends hanging at the side. A curl hangs over the left shoulder. The dress is cut low in the neck and sleeves and is trimmed with lace reaching to the elbow. She was born in I75I and died October 28, I793. Her husband was William Dawes, whom she married in 1768. They lived prior to the Revolution at $64 \mathrm{Ann}$ Street, Boston. The portrait is now in the possession of A. N. Holland of Concord, Mass.

\section{Judge Thomas Dawes}

This portrait, which has always been in the family, according to his grandson, the Rev. Thomas Dawes, of Brewster, Mass., represents him as a boy dressed in the fashion of the times, with his hat under his arm and an orange in his hand. The picture is about four feet long by three feet wide. Judge Dawes was born in 1757 and was a graduate of Harvard College in 1777. He married Margaret, daughter of William, and granddaughter of the Rev. Daniel Greenleaf. He was a Judge of the Supreme Court of 
Massachusetts from 1792 to I802, when he resigned. He was afterwards appointed Judge of Probate for Suffolk, and held that office until 1822. He died in 1825. This portrait is the property of the Rev. Mr. Dawes, and is in the possession of his sister, Mrs. Minot.

\section{Mrs. Deas and Children}

This group picture consists of four female figures and a dog, and represents Mrs. John Hartley, Mrs. Deas and children, one of whom became Mrs. John Ward and the other Mrs. William Somersall. The smallest child is in a pink dress, the oldest girl in gray silk with a blue sash, the elderly woman is in black with white neck scarf and bonnet. The mother is in the background and the child about six years old in the foreground. This picture was exhibited at the Metropolitan Art Museum during the Hudson-Fulton celebration in 1909. Size, fifty by seventy-six inches, and owned by D. Maitland Armstrong, of New York.

\section{Death of Major Pierson}

This large picture hangs in the National Portrait Gallery. The female figure with the child in her arms was painted from a nurse in the Copley family. The figure between her and the wall is Mrs. Copley, and a 
boy in green running by the side of the nurse is young Copley. It has been engraved by Heath. The first sketch for this picture was sold at the Lyndhurst Sale in 1864 , and the original picture was painted for Alderman Boydell, but was repurchased by Copley. It was bought at the Lyndhurst Sale for $£_{1}, 600$.

There is a portfolio of first sketches for this picture in the possession of Lord Aberdare at his London house.

\section{Gilbert DeBlors}

Was a distinguished merchant of Boston, a determined loyalist, holding offices under the British Government. He built the fine old mansion known as the De Blois house, which stood where the Horticultural Hall now is. An addressor of Governor Hutchinson in 1774 and of Governor Gage in I775, in $\mathbf{I} 778$ he was proscribed and banished. In $\mathbf{I} 794$ he presented an address to King George III., in London, where he remained for many years, and where the picture was painted. Mr. De Blois is represented sitting partly in profile, dressed in a brown coat with a white wig. His right hand rests upon a table in front of him, holding a pen, and over his head is a crimson curtain, with sky in the background. It is a fine specimen of Copley's latest manner. It now belongs to Mrs. C. H. Parker of Boston. 
Major-General De la Motte

A fine study head made for the "Siege of Gibraltar," of life size, is owned by Mrs. F. Gordon Dexter.

\section{Mrs. Elizabeth De Lancey}

A portrait of this lady who was the mother of Mrs. Ralph Izard, measuring twenty-five by thirty inches, said to be by Copley, was sold at auction in 1912.

\section{Mrs. Lanfrey Delisle}

Was Bathsheba, daughter of Judge Metcalf Bowler. She married a French gentleman who came to this country with Lafayette. By a letter from her dated 1785 , we learn that she arrived at the country seat of her father-in-law, near Grenoble, in safety, and was most kindly received by her husband's family. The marriage seems to have been a very happy one. Her portrait is a miniature on ivory, one and onequarter inches long by one inch wide. It was taken - before her marriage and represents the head and shoulders of a young lady, with her hair rolled back, dressed with flowers. Her dress is of pink, with a "bouquet de corsage." The portrait was in the possession of her grand-niece, Mrs. M. Knight, Brooklyn, N. Y. 


\section{Dr. De Mountfort}

The size of this picture is twenty-five inches by thirty, and represents a child with hair powdered, a blue coat, and a yellow waistcoat. In the background are rocks and the sea. The boy holds in his hand a wreath of flowers. This picture is signed J. S. Copley, I753, and is especially interesting, as it must have been painted when the artist was under sixteen years of age. It is almost the earliest known specimen of Copley's work, and is in the family of Mrs. C. D. Farlean of Detroit, Mich.

\section{Mrs. Richard Derby}

First wife of Richard Derby. This is a very large picture, in Copley's latest manner, of a lady dressed in white, ornamented with gold. She is represented as St. Cecilia, playing on a harp, and angels are flying in the air above her. It is signed and dated I806, and belongs to the estate of Miss Marjorie C. Appleton.

\section{Mrs. Devereux}

Copley painted a portrait of a lady by the name of Devereux in I77I. Copley says in a letter to John Greenwood, the painter and engraver, under date of January 25, I77I, "No engagement should have hindered me from answering your favour, had I not 
fully intended to have finished Mrs. Devereux' portrait for Captain Sims to have carried, but was prevented from my design by several circumstances, the most material that of the weather being so hot as to make it inconvenient for the old lady to come to town."

\section{John Douglas}

This is an excellent example of Copley's English portraiture. Although an American, John Douglas resided in England during the early part of the Igth century. His wife was Lydia Lapham. The picture measures twenty-five by thirty inches and represents the subject at life size and half length, showing the face nearly full front with a white wig. There are muslin ruffles at the neck and sleeves. The coat is dark green lined with red which shows at the lapel. His right hand is resting on a table holding a book. On the table is a pipe and cup and saucer. The picture has always been owned by the descendants and now belongs to Edward Carrington Bates of Boston.

\section{Judge Duane}

In the Documentary of New York, Vol. IV., page 654 , it is stated that there was a portrait of this gentleman, painted by Copley. It is said now to be in the possession of a great granddaughter, Mrs. D. C. Western, of Madison, New Jersey. 


\section{Mrs. James Duane}

A portrait of this lady by Copley is owned by Dr. Alexander Duane of New York, who is a great great grandson of Mrs. Duane. It measures $25 \times 30$ inches.

\section{Colonel Duchenhausen}

A fine portrait study head for the large painting of the Siege of Gibraltar. It is owned by Mrs. F. Gordon Dexter of Boston.

Sir George Jackson Duckett

According to the National Biographical Dictionary, Copley painted a portrait of this gentleman. It is now owned by Sir George Duckett, Baronet. The subject of the portrait was born in 1725 and died in I 822.

\section{Viscount Dudley and Ward}

This group portrait was exhibited in the Royal Academy in 1800 and again in 1804 , and is now at 7 Carleton Terrace, London.

\section{Lady Dudley and Ward}

This group portrait was exhibited at the Royal Academy in 1800 . It is now in London at 7 Carlton Terrace. 


\section{DUKE OF YORK}

This portrait shows the subject as a young man in the full uniform of a British officer. It is of threefourths length. His right hand is by his side holding a glove, and his left arm, hand extended, rests on his sword hilt. The portrait is in the possession of Mrs. Langarbach in England.

\section{James Dumarese}

Son of Philip and Rebecca Dumaresq. A half length portrait in oils, which was sent to his brother, Francis Dumaresq, of Jamaica, West Indies, where it is believed still to be.

\section{Rebecca Dumarese}

This picture is an oval crayon, twelve inches long by eight wide. The lady was the daughter of Dr. Sylvester Gardiner. She was born in $\mathbf{1 7 4 5}$, and was married in $\mathbf{I} 773$ to Philip Dumaresq, a grandson of Hellier Dumaresq, Seigneur des Augres of the Island of Jersey. Philip Dumaresq was a captain in the British army and served at Louisburg and elsewhere under Sir William Pepperell. He was also at one time an aide-de-camp to Lord Dunmore. A determined loyalist, he was proscribed and banished

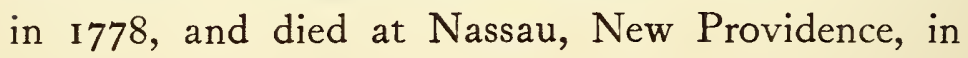


I812-I3. This picture was made in 1763 and formerly in the possession of her granddaughter, Mrs. John Rice Blake, Boston, and now belongs to Mrs. W. Austin Wadsworth of Boston.

\section{Rr. Hon. Lord Viscount Duncan}

This is a three-quarter length portrait showing him as Admiral, with left hand resting on a cannon, and right holding his sword and hat. A burning frigate is in the background on the left and the side of a ship with its rigging on the right. It was engraved by Earlom and published by Copley in $\mathbf{I} 798$.

\section{Mr. Robert Dundas}

A portrait of this gentleman is owned by Lord Aberdare and is in London.

\section{Josiah Eliot}

A crayon of one half length. This picture was in the possession of Miss Hull of Fairfield, Conn.

\section{Mrs. Nathaniel Ellery}

She was Ann a daughter of William and Mary (Duncan) Sargent, of Gloucester, and a sister of Colonel Epes Sargent. She was married February I6, I72I, and died October 8, I782. The size of this picture is forty by forty-nine inches, and was taken about 1760 , when the lady was about seventy years 
of age. She is in a sitting posture, with a watered silk dress, a bodice, and an inside lace handkerchief. Her shawl is of black lace, thrown over her shoulders, and short sleeves with ruffles, complete the costume. She is holding an open book in her hand. This picture is now in the possession of Mrs. N. Martin Rogers, Cambridgeport.

\section{Frances Cadwallader Erskine}

She was born in 1781 , died in 1843 , was a sister of General Thomas Cadwallader, and married David Montague Erskine, who was a son of Thomas Erskine, first Baron Erskine, and on the death of his father became second Baron Erskine. This picture is a fine example of Copley's late English work. It shows Lady Erskine in a half length standing position. She wears a dress of golden brown, lace at the sleeves, and her hair dressed high with a pearl net, surmounted in front with flowers. She has a collar and earrings of garnet beads, has a bunch of roses in her corsage, and holds a small rose in her right hand, which is crossed over the left hand. It has a landscape background. The picture measures thirty by forty inches and belongs to Mrs. James M. Codman of Brookline.

\section{JAMES ERving}

Was the fourth son of the Honorable John Erving. This portrait is a miniature of oval form, and there is 
a tradition in the family that "it was the first miniature in oil that Copley made." It is owned by J. Langdon Erving of New York.

\section{Hon. John Erving}

This gentleman was a distinguished citizen of Boston, and the father of Mrs. Governor Bowdoin. He was born in 1693, started in business as a ferryman on the Charles River, and left one of the largest fortunes of the day. He resided on the estate at the corner of Tremont Row and Howard Street, afterwards occupied by Governor James Bowdoin.

The portrait is owned by J. Langdon Erving of New York.

\section{Captain John Evans}

There is a portrait of this gentleman in the National Museum, at Washington, D. C.

\section{Family Portrait}

The picture shows the artist and his family, life size. The old man before him is Mr. Clarke, his father-in-law, famous as the consignee of the cargo of tea of the "Boston Tea Party." Mrs. Copley, on the sofa, is carressing their son John, afterwards Lord Lyndhurst. This is one of Copley's best paintings. It shows the English manner and yet retains the best 
qualities of his American work. It is in the Boston Museum of Fine Arts, lent by Mr. Copley Amory. It was completed in England in $\mathbf{1} 802$.

There is an original sketch in sepia, from which the family picture is painted, twenty-seven inches long by twenty-one wide. Mrs. Copley is represented as seated on a sofa, her arm resting on her son, the future Lord-Chancellor Lyndhurst, whose arm is thrown around her neck. Her daughter Mary leans upon her other side, while her daughter Elizabeth stands in front, on her right. Mr. Clarke, the father of Mrs. Copley, sits holding the infant Jonathan, playing with a rattle upon his lap. This child died in I785. Mr. Copley stands behind, against a column of the balcony, and holds in his hands a scroll. In a corner of the floor are a child's hat and feathers, and a landscape of trees forms the background. This picture is now owned by Ingersoll Amory of Boston.

A copy of the original sketch for the large picture is owned by Mr. Frederic Amory.

A study for the portrait of Mrs. Copley holding the infant, afterwards Lord Lyndhurst, made for the family group, is owned by Miss Mary Amory Greene and lent to the Boston Museum of Fine Arts. 


\section{LORD FAUCONBERG}

This handsome portrait of Henry Bellasyse, 2d Earl of Fauconberg, is owned by Mrs. F. Gordon Dexter of Boston. It is half length, life size, representing him dressed in a red coat with gold epaulets, holding the pommel of his sword. A coat of arms is in the upper part of the picture. He lived opposite $\mathrm{Mr}$. Copley's house in London. He was born 1743 and died in 1802 . This picture was engraved by Heath in 1794 .

\section{Dr. Samuel Fayerweather}

This picture is a miniature painted on copper. It is of half length, three inches long by two and one half wide, and is in the original silver frame. It represents the doctor in his Oxford cap and hood, and wearing a full wig with a black silk robe. Dr. Fayerweather was a son of Mr. Fayerweather of Cambridge. He graduated at Harvard College in I743, was A. M. of Oxford in 1756, and Cambridge, England, in 1758 . He was ordained Deacon by Dr. Pearce, Bishop of Bangor, in $\mathbf{1 7 5 6}$, and was admitted to full orders by Dr. Richard Osbaldiston, Bishop of Carlisle. He was licensed to exercise the ministerial function by the Bishop of London. On his return to this country he was settled at Kingston, R. I., 
as the Rector of the Episcopal Church there. He married the widow of the Rev. Peter Bours of Marblehead, and died in $178 \mathrm{I}$. The miniature with the certificate of his Oxford degree, is in the possession of his relative, Edward D. Harris of Yonkers, N. Y.

A large picture of Dr. Fayerweather is now owned in Rhode Island. Both pictures are named in his will.

\section{Colonel Fitch and Sisters}

The portrait of Colonel Fitch of the British Army and his two sisters, Miss Ann Fitch and Mrs. Leonard Vassal, was painted by Copley for Mr. Lloyd, their uncle, in 1800 , and exhibited in the Royal Academy in 1801 . Soon after the picture was painted Colonel Fitch was killed in the West Indies. The figures are of life size. Colonel Fitch, dressed in his uniform, is standing with his horse; Miss Fitch is dressed in black, and Mrs. Vassal is in white. This large and important work was exhibited in the Boston Museum of Fine Arts for many years, and belongs to Mrs. Gordon Abbott of Boston.

\section{Tімотну Fiтch}

Was a distinguished merchant of Boston. The size of this picture is five feet long by four feet wide, and was painted between 1760 and 1767 . It is in a 
fine state of preservation, and is of life size. It represents a gentleman seated by a table, on which is a cocked hat and a letter bearing an address. The costume is a gold laced coat and waistcoat, with a white wig and silk stockings. This picture is in the Essex Institute, Salem.

\section{Mrs. Tiмотнy Fitch}

Was born in I73I. She was the daughter of Colonel John Browne. The Brownes were an old English family, distinguished and wealthy in the days of Salem's Colonial prosperity. She married for her first husband Mr. Ichabod Plaisted, married Mr. Fitch in 1760 , and died in I799. She is represented as sitting, holding her work near a small table. Her dress is of a purplish pink satin, with blue lining. The sleeves are loose and caught up at the elbow, her hair is without powder, and behind her is a heavy green drapery. This picture is in the Essex Institute, Salem.

\section{Thomas Fleet}

This picture is of full length, in an oval painted panel, and the subject was a son of Thomas Fleet and Elizabeth Goose, his wife, the celebrated Mother Goose of our childhood. He was born in 1732 and died in 1797. The portrait has always been in the 
family, and it is known that Copley and Fleet were on intimate terms from boyhood. The picture was in the possession of a descendant, John F. Eliot, of Boston.

\section{James Flucker}

He was a son of Thomas Flucker, the last Royal Secretary of the Province of Massachusetts. The bill for this picture is included with his father's and reproduced under the latter's portrait.

\section{Thomas Flucker}

Born I719; died 1783; he was the last Secretary of the Province of Massachusetts before the Revolution. The size of the portrait is twenty-nine inches long by twenty-four wide. Both face and figure are turned one quarter round from the viewer to the left. The coat and waistcoat are in the fashion of the day, without collars, and buttoning single-breasted to the throat. They are of a bluish gray tint. He wears a gray wig, and the ordinary cravat of the time. Secretary Flucker was the great grandfather of Admiral Henry Knox Thatcher, United State Navy, and the picture came into the possession of Bowdoin College under the will of Mrs. Lucy F. Thatcher of Rockland, Maine. The following is a correct copy of the bill for the picture. 
Boston The Honble Thomas Fluker Esqr.

1774 to Jno. S. Copley, Dr.

June

To his own portrait

$£_{14}$.0.0

To his Sons. Do.

I 4.0 .0

28.0 .0

To two black and Gold Frames at $\mathfrak{f I}_{\mathrm{I}} 8$

$$
\text { Totlg } \frac{2.16 .0}{£_{30.16 .0}}
$$

\section{Timothy Folger}

This picture measures forty by fifty inches, and is in its original carved frame. It represents a middle aged man, three-quarters length, dressed in dark brown, with white wig. The picture now belongs to Mr. Munn of New York.

\section{Mrs. Dorothy Forbes}

Was a daughter of James Murray, born in London in $\mathbf{1 7 4 5}$. She came to America with her parents in I749 and married the Rev. John Forbes in 1769. Her portrait hangs today in the home of her youth, where she lived one hundred and forty years ago. She was the grandmother of Robert Bennett Forbes and John Murray Forbes, and died at Milton in I8II. The picture is thirty-seven inches high by twenty- 
seven wide, and represents her as dressed in yellow satin, ornamented with silver lace. She wears a large hoop, and her hair, which is brushed over a cushion, is decorated with a white bow. Her earrings are of pearl, and a necklace of the same encircles her throat. The portrait is in the possession of Mrs. Sarah Forbes Hughes of Milton.

\section{Mrs. Seymour Fort}

This is a full length seated figure of an elderly lady in white cap. Her work bag hangs on the chair arm and she appears to be engaged in tatting. The picture was exhibited at the Hudson-Fulton Exhibition in the Metropolitan Art Museum. It is now in the possession of the Wadsworth Athenaeum of Hartford, Conn.

\section{Eleanor Foster}

Afterwards Mrs. Nathaniel Coffin of Portland, Maine. This is a very early portrait, dated I755, made when the artist was only eighteen years old, but is undoubtedly a genuine example of his work of that period.

\section{Captain Isaac Foster}

Of Charlestown, representing him standing, the picture being three-fourths length. He is dressed in a slate colored costume of the times, and he carries his 
hat under his arm. This portrait is in the possession of Mrs. David Buffum of Walpole, N. H.

\section{Mrs. IsaAc Foster}

A companion picture to that of her husband. This portrait is owned by a descendant, Mrs. David Buffum of Walpole, N. H.

$$
\text { Dr. IsaAc Foster, Jr. }
$$

A son of Captain Isaac Foster represented as a youth of about fifteen years old, and a companion picture to that of his brother. It is owned by Mrs. Philip Peck of Walpole, N. H.

\section{Dr. William Foster}

A son of Captain Isaac Foster. A portrait of threefourths length, now belonging to a descendant, Mrs. Philip Peck of Walpole, N. H.

\section{Colonel Fowle}

There was a portrait of Colonel Fowle of Marblehead in the possession of the heirs of William Fowle of Alexandria, Va.

\section{Governor FrankLin}

Of Vermont. "There is a portrait of this gentleman, by Copley," says Mr. Thomas H. White, of Shelburne, "in the possession of the widow of the late Rev. Fitzgerald Uniac, who has possibly another one." 


\section{Gallatea}

This allegorical picture showing Gallatea drawn by the Dolphins is interesting as showing Copley's early interest in such compositions and manner of execution. It was purchased by the Boston Museum of Fine Arts in 1907 from Mr. Henry E. Spaulding.

\section{General Thomas Gage}

In a letter to Copley from Captain Small, dated "Headquarters, New York, I769", Captain Small says, "Your picture of the General is universally acknowledged to be a masterly performance! In short it has every property genius, judgment and attention can bestow on it." The picture was hung in Lord Gage's house in Arlington Street, London, between two portraits of Lord and Lady Gage by Reynolds. Gage was born I721; died 1787; Aide-de-camp to Lord Albemarle in Flanders, $1747-8$; as LieutenantColonel of the 44th Regiment under Braddock in America raised 8oth Foot and commanded light infantry at Ticonderoga in 1758; commanded as Brigadier-General the rear guard of Amhearst; Governor of Montreal, I759-60; Major-General I76I; Commander-in-Chief in America, 1763 to 1772 ; Lieutenant-General I770; Governor of Massachusetts, I774-5; and was superseded by Howe, October, I775. 


\section{Mrs. Thomas Gage}

This portrait of the wife of General Gage was made in New York the latter part of $\mathbf{I} 77 \mathrm{I}$ and exhibited in London in 1772 , and catalogued as "A Lady, half length." In a letter dated December 20, $\mathbf{1 7 7 2}$, to Copley from Jonathan Clarke, the latter quotes Benjamin West as follows: "I found Mr. West a great admirer of your portraits. You seem to think by your letter to him that the one you last exhibited was not asteemed so good a one, but Mr. West thinks you was under a mistake, for Mrs. Gage's picture was thought a very fine one." And Benjamin West said again under date of January 6, I773, "The portrait of Mrs. Gage as a picture, has received every praise from the lovers of art."

\section{John Gardiner}

The second son of Dr. Sylvester Gardiner, born in Boston, educated in London at the Inner Temple, and died 1794. He defended John Wilkes before Lord Mansfield in 1763, and was Attorney-General of the British West India Islands in $\mathbf{1 7 7 8 . ~ H e ~ w a s ~ a ~}$ Representative in the Massachusetts Legislature from I789 until his death. "He had," says Updike, "an astonishing memory, was an admirable belle-lettre scholar, very learned in his profession, and particu- 
larly distinguished for wit and eloquence." The figure is of three-fourths length. He is dressed in a brown coat, laced waistcoat, and is sitting at a table with books and papers. This picture is in the possession of Mrs. C. P. Gardiner of Brookline.

\section{The Little Gardener}

A picture bearing the above title was sold at Christie's, London, in April, I9I4, from the collection of Edward, first Earl of Ellborough.

\section{Dr. Sylvester Gardiner}

He was the son of William Gardiner and Abigail Remington, and was born June 29, I708. He was educated in Europe as a physician and surgeon and settled in Boston. He had three wives, and his children were as follows: John; Anna, who married Robert Hallowell; Rebecca, wife of Philip Dumaresq; and Abigail, wife of Oliver Whipple. A determined loyalist, and an addressor of Governor Hutchinson, he was banished in 1778 , at which time his landed property, amounting to one hundred thousand acres of land, was confiscated. He was the founder of Gardiner, Maine, and died at Newport, R. I., in I787. The picture is of life size, three-quarters length, a sitting figure, dressed in a red coat, ornamented with gold buttons. His right arm is resting 
on a table and the left hand is in his coat. This fine portrait is in the possession of his great-grandson, R. H. Gardiner, of Gardiner, Maine.

Mrs. Sylvester Gardiner

She was Ann, the daughter of Dr. Gibbons, a first wife of Dr. Gardiner, to whom she was married in King's Chapel, Boston, December II, I732. She died in I77I. The picture is three-quarters length, life size, and shows the lady seated, her dress trimmed with lace at neck and sleeves; her left hand in her lap; her right arm extended on the back of the couch on which she is sitting. The portrait belongs to $\mathrm{Mr}$. Robert H. Gardiner.

\section{Major Thomas Goldthwait}

He served with distinction at several important posts. He married as his first wife, Esther Sargent, daughter of Epes Sargent, and for his second wife, Katherine Barnes. The portrait of this officer is in the possession of Dr. J. T. Bowen of Boston.

\section{George III. and his Queen}

Painted for Governor Wentworth of Portsmouth. It is now in England.

\section{George III.}

George William Frederick was born 1738 and died in 1820 . One of several portraits of the king is that 
by Copley owned by the Beebe family of Boston. It is a fine example of the late English period and in excellent condition. It measures forty by fifty inches and is of life size. The subject is shown seated at a table. The right hand rests on a portfolio and the left hand points to a document on the table. The dress is a dark green, richly embroidered, and a crimson sash. There is lace on the sleeves and collar.

\section{George IV}

This large and important picture represents the King when Prince of Wales, mounted, witnessing a review, attended by Lord Heathfield, General Turner, Colonel Bloomfield, Baron Eben, and Colonel Quinton. It was exhibited at the Royal Academy in 1809. An engraving was published of this picture by Copley and Colnaghi in 1813 , and is now owned by Mrs. F. Gordon Dexter of Boston.

\section{Benjamin Gerrish}

This picture is of life size and of three-fourths length, being twenty-five inches wide by thirty long. Mr. Gerrish is dressed in a brown coat, laced cravat and ruffles, and wears a powdered wig. He was the son of John Gerrish and the brother of Mrs. Sarah Barrett, who bequeathed this picture in her will to her youngest son, John Barrett. Mr. Gerrish, who 
was one of the founders of the new North Church, died in I777. The portrait was in the possession of a grand nephew, Nathaniel Augustus Barrett of Boston and belongs now to the estate of Mrs. S. D. Barrett.

\section{Joseph Gerrish}

This portrait is a late example of Copley's American work. It is half size in length and shows him with face slightly turned, white wig and white neck cloth. It was owned by Mrs. Samuel E. Barrett of Chicago.

\section{Governor Moses Gill}

The size of this picture is forty-nine inches high by forty inches wide, with a handsome carved gilt frame. Governor Gill was the son of John, the second son of Colonel Gill. His mother was Elizabeth Abbott of Charlestown, a sister of the Rev. Hull Abbott. He was born in 1733 and died in 1800 , aged sixty-seven. The portrait was painted when he was about thirtythree years of age. He married for his first wife, Sarah, only child of Rev. Thomas Prince of Boston. His second wife was a daughter of Thomas Boylston. $\mathrm{He}$ is represented as a fine-looking man, with black eyes and a well-shaped forehead. He wears a powdered wig, and the hair crêped at the ears. His dress is a dark blue single-breasted velvet coat, lined with 
white satin, unbuttoned, and held back to the hip by the right hand. The sleeves are very large, with deep cuffs fastened up with two buttons, the shirt sleeves coming below, terminating with a very narrow band of linen cambric. He wears a very long, white satin waistcoat, and a muslin cravat is around the throat. The hands are beautifully painted, especially the left one. Between the fingers is held a paper, addressed to Mr. Moses Gill, Boston. For the background on the right is a long, white window shutter, with bluish green drapery; on the left is part of a desk, with a green velvet cover. This picture is now in the Rhode Island School of Design.

\section{Mrs. Rebecca (Boylston) Gill}

The second wife of Governor Gill and daughter of Thomas Boylston. The size of this picture is forty by forty-nine inches with a fine frame of antique style. She is represented with a handsome face, dark blue eyes, and black eyebrows. Her hair is black, carried entirely off her forehead and temples, and arranged high with a scarf of reddish brown, dotted with gold, and fastened at the top with a few pearls. The scarf is carried over the right shoulder, and falls over the arm in front. She is standing by a garden vase, containing a lily, with many dark leaves and flowers in blossom. Her left hand rests on the edge of the 
vase, and in the right hand, which is most beautifully painted, she holds a lily. Her dress is of blue velvet, or satin, with an embroidery of gold in a red velvet band around the bosom. There is a girdle of the same kind, about three inches wide, around the waist. The tucker of point lace is most exquisitely painted. A crimson drapery hangs gracefully over the back of the dress, and falls over the arm in front. On the left is a pillar. Behind her figure there is a dark background of brown and green. At a distance, on the right, is a glimpse of sky, with a portion of the trunk of a tree, and with the green leaves of a vine entwined around it. This picture is in the possession of the Rhode Island School of Design.

There is a portrait of this lady, signed in monogram, dated 1767 , in the Boston Museum of Fine Arts, lent by the Estate of Louisa C. A. Nightingale.

\section{Mrs. Relief (Dowse) Gill}

This picture is forty-nine inches high by forty wide. It represents a very old lady, having a pleasant, benevolent face, with large blue eyes. She has a little dark hair showing beneath a white lawn cap. Her dress is of brown velvet, opening to the waist in front, and filled in with a white lawn handkerchief. Over her shoulders is thrown a black thread lace shawl. 
The sleeves reach to the elbows. Below them appear white lawn sleeves with ruffles, leaving the wrist and hand uncovered. In her right hand she has a book held slightly open, with her thumb between the leaves. Her left hand, which shows the effect of years, is laid partly over the other. She is sitting in a stuffed armchair, covered with a greenish blue material, the back of which is as high as the top of her head. She was probably eighty-three years of age at the time the picture was taken, 1759. It is worthy of note that the name of Relief, bestowed upon the mother of Mrs. Dowse, whose maiden name was Relief Holland, has been continued down in the female line for six generations. Relief Dowse married Michael Gill, and settled in Charlestown, Mass. Captain Gill made many prosperous voyages to various parts of Europe, and left a large estate of his prosterity. At his death he was a colonel of a colonial regiment. On his monumental stone it is recorded that he died in 1720, aged forty-seven. His widow survived him thirty-nine years. The portrait belongs to $\mathrm{Mr}$. Robert Pratt of Boston.

\section{Mrs. Sarah (Prince) Gill}

The first wife of Governor Moses Gill; was the only child of Rev. Thomas Prince; born July 16, I728; married April, I759, and died August 5, 1771. The 
size of the picture is forty by forty-nine inches in a handsome carved frame of antique style. She is represented as having a very refined and intellectual countenance, with black hair carried off from her forehead and temples, with strings of pearls entwined. Of dark complexion, she has black eyes and eyebrows, with delicate features. She is sitting, with her right arm resting on what appears to be a portion of a tree, with dark olive background, excepting towards the left, where there is an opening of sky, with blue hills in the distance, and an oak tree in the middle distance. She is dressed in a dark blue velvet robe, with muslin undersleeves reaching below the elbows, and with double ruffles. Four rows of pearl beads encircle the throat, one row coming down over the left shoulder to the middle of the bust, where two long loops fall over the bows of white lace scarf, edged with gold, and embellished with gold sprigs. The scarf has a broad end in front, and is very prettily draped over the arm and sleeves to the back of the dress. The right hand falls gracefully from the support on which it is resting, and in her left hand she carries a book, held slightly open with her thumb. This picture is now in the Rhode Island School of Design.

A crayon portrait of this lady is also in existence. 


\section{Jonathan Glover}

Colonel Jonathan Glover was born in Salem, June 13, 1731. He was a colonel in the State Militia and brother of General John Glover of Revolutionary fame. He had two other brothers, Samuel and Daniel. This is a very fine pastel portrait about eighteen by twenty-two inches, life-size head and bust, and in good condition. It belongs to Miss Sarah Crocker of Boston.

\section{Mrs. Jonathan Glover}

Was Abigail Burnham, daughter of Job Burnham of Ipswich, and married Colonel Glover, October ro, I748. This is also a fine example of Copley's pastel portraiture and is companion in size to that of her husband. It belongs to Miss Sarah Crocker of Boston.

\section{Ezekiel Goldthwait}

He was at one time Register of Deeds. The picture is of life size, and of three-fourths length, representing a gentleman dressed in a brown coat, and wearing a white wig, seated at a table on which are pens and an ink stand. In his right hand he has a pen, while the left holds a deed, the arm resting on the back of the chair. Over his head is a curtain. The portrait is owned by Dr. J. T. Bowen of Boston. 


\section{Mrs. Ezekiel Goldthwait}

A companion picture to that of her husband, representing the lady as sitting at a table, on which is a dish of fruit. Her right hand rests on the table. Her dress is of satin, of the shade called ashes of roses, beautifully painted. Her hair is without powder, around her neck are three rows of pearls, and a cap completes the costume. It belongs to Mrs. Louisa M. Alline.

\section{Major Joseph Goldthwait}

Was born in Boston, October 5, 1730, married Miss Hannah Bridgham, and was a brother of Philip Goldthwait. He was a major of the British Army in Boston in 1775, was a determined loyalist, and an addressor of Governor Hutchinson, and was proscribed and banished. The picture is twenty-seven inches by twenty-two, unfinished, and has been admired by artists on account of the vigorous manner in which the subject is treated. It is now owned by Miss Adams of Keene, N. H.

\section{Gore Children}

There is at the house of the Misses Robins of Boston a painting of the portraits of the Gore children, brothers and sisters of Governor Gore. If by Cop- 
ley, it is a very early one. It contains portraits of Frances Gore, who married Col. Thomas Crafts; Miss Gore, who married Mr. Taylor; Samuel Gore who married Mary Pierce; and John Gore, who married Sarah Foster. The author does not feel sure of the authenticity of the picture.

Another picture contains portraits of Governor Gore when a child, and his sister, at the house of $\mathrm{Mr}$. Edward B. Robins.

A third picture has the portraits of two of the sisters.

\section{Joshua Grafton}

A miniature of Mr. Grafton is in the possession of a descendant, Mr. J. Grafton Minot. It is oval in shape, full face and a fine example of Copley's work, beautifully framed.

\section{J. A. Graham, LL.D.}

A portrait of this gentleman was shown in the Royal Academy in $\mathbf{1 7 9 8 .}$

\section{Sir Robert Graham}

This example of Copley's latest and best English portraits represents Baron Graham in his robes of office. It was exhibited at the Royal Academy in I804 and is now owned by Mrs. F. Gordon Dexter. 


\section{Mrs. Gideon Granger}

A portrait of this lady who was a Dandridge is owned by Miss Adele G. Thayer.

\section{Harrison Gray}

This picture is of life size and half length. The dress is of brown velvet, with steel buttons and with lace at the wrists and neck; a gray wig dressed with a queue completes the costume. He was the Receiver-General of Massachusetts and an addressor of Governor Hutchinson, and Councillor. He was proscribed and banished during the Revolution. "Mr. Gray," says Sabine, "was an exemplary gentleman in every relation, and among the loyalists there is hardly one more deserving of respect and kind remembrance." The portrait is now in the possession of Mr. Harrison Gray Otis of Needham, Mass.

\section{John Gray}

A relative of Harrison Gray Otis. He is represented as standing, dressed in a brown coat, with a white satin waistcoat, lace cravat and ruffles. This picture was loaned lby the Misses Rogers to the $\mathrm{Mu}$ seum of Fine Arts, Boston, April I908. 


\section{Mrs. Gray}

Mr. William Carson, writing from Newport in August, I772, to Copley says, "Your painting of the squirrel was a modest production, and your picture of Mrs. Gray in crayons could only testify that it was one fine face, and you a man of some genius."

\section{General Greaton}

A portrait said to be in New York.

\section{Joseph Green}

A merchant of Boston, born December I2, I703, and died July I, I765. He was the son of the Rev. Joseph Green, of Salem Village, now Danvers, who was graduated at Harvard College in 1695. It is a crayon of life size and half length. The costume is a single-breasted coat and waistcoat of a dark color, with large embroidered buttons. The cravat is white, and the shirt ruffles are slightly exposed. A full powdered wig completes the picture. The coloring is as fresh and perfect as if just from the artist's hands. It is in the Boston Museum of Fine Arts, to whom it was presented by Dr. Samuel A. Green in I9IO. 


\section{Councillor Joseph Green}

This beautiful and characteristic picture is a crayon of life size and half length, representing him in a morning costume of dark gray. He wears a cap of the same color, and his collar is thrown open. Joseph Green was born in Boston in 1706 , and graduated at Harvard College in 1726 . He was a merchant, and had a large fortune. He was celebrated as a scholar, a poet, and a man of wonderfully ready wit, which he often showed in his contests with a fellow wit, the Rev. Dr. Byles. At the time of his death he had probably the most beautiful and valuable private library in New England, some volumes of which have descended to the heirs of the Rev. William T. Snow. His residence was on School Street, just above the "Cromwell's Head Inn." Mr. Green was a Mandamus Councillor, an addressor of Governor Hutchinson, and was proscribed and banished. He died in England in 1780 . This picture belongs to Miss $\mathrm{H}$. Elizabeth Snow and is lent to the Boston Museum of Fine Arts.

\section{Mrs. Joseph Green}

A companion picture to that of her husband. She is represented as in a dress of blue velvet, trimmed with ermine. She wears pearls in her hair and around her neck. This picture is in the possession of 
Miss H. Elizabeth Snow and is lent to the Boston Museum of Fine Arts.

\section{Mrs. Louis Jenkins}

She was the youngest daughter of Robert Hooper. This is a crayon, measuring eighteen by twentythree inches. The dress is salmon pink, the hair is combed back and she has a spray of hawthorn in her hair. A blue mantle is over her shoulder. A small miniature was made in the form of a locket of this lady in a dress of pink. Both these portraits belong to Miss Sarah Currier of Newburyport, Mass.

\section{Benjamin Greene}

The father of the Gardiner Greene who married the eldest daughter of Copley. He is represented as sitting sideways upon a chair with his face in profile. The dress is a rich blue suit and a full wig. His right hand rests upon the back of a chair, while his left is thrust into a flowered waistcoat. He is looking towards a table on which are papers and a pen. The picture is of three-fourths length and in the original frame. It was in the possession of the heirs of his grandson, the Rev. John S. C. Greene of Longwood, and was destroyed in the great fire of $\mathbf{I} 872$.

A fine miniature of Mr. Greene is owned by Mrs. Dwight F. Prouty. 


\section{Lieut. Francis Greene}

Was an officer in the British Army, holding a commission in the Fortieth Regiment of Infantry. He served in the old French war, at Louisburg, and in Canada, also in Martinique and Havana. He graduated at Harvard College in 1760 , and wrote much on the subject of the education of the deaf and dumb. He died at Medford in I809. The size of this picture is two feet six inches long by two feet wide, of half length; he is dressed in the full uniform of a lieutenant in the British army. In one corner is Copley's monogram and signature, with date, I763. The picture was in the possession of Lieutenant-Commander Francis Matthews Greene, U. S. N.

\section{Gardiner Greene}

The son of Benjamin and Mary, was born in Boston in 1753 , and died Dec. 19, 1832. He married, first, Ann Redding; second, Elizabeth Hubbard; and third, in London, in 1800 , Elizabeth Clarke, the daughter of John Singleton Copley, the artist, and sister of John, Baron Lyndhurst, sometime Lord Chancellor of England. He was eighth in direct descent from Robert Greene of Gillingham, in the time of Henry the Eighth, and was a distinguished merchant of Boston. The portrait is of half length. The figure is seated 
in a chair, dressed in a blue coat with brass buttons. The hair is powdered. It is a fine specimen of Copley's latest manner. The picture was presented by the Lord Chancellor Lyndhurst to his nephew, the Rev. John Singleton Copley Greene, of Longwood, Mass., and was burned in the great fire of $\mathbf{1} 872$.

\section{Mrs. Gardiner Greene}

A companion picture to that of her husband. She was Elizabeth Clarke, daughter of John Singleton Copley, born in 1770, and died in February, 1866, at the age of ninety-five. She married Gardiner Greene of Boston in 1800 . The picture is of half length and was painted by her father just before her wedding, for a keepsake. She is dressed "a la Josephine" in white muslin, with a shawl thrown over her arm. This picture is in the possession of Mrs. F. Gordon Dexter of Boston.

There was a portrait of Mrs. Greene, probably a study for the family picture, but its whereabouts is at present unknown.

Gardiner Greene and Mrs. Murray

A portrait of Mr. Greene when he was but twelve years of age, and his aunt. This picture is of threefourths length, representing the lady dressed in a pearl-colored satin, trimmed with rich lace, her hair 
without powder. She is seated, with her right hand resting on the boy's shoulder, while she holds his left hand in hers. The boy stands by her side dressed in a brown coat lined with blue silk. In his right hand he holds his hat. This beautiful picture was in the original frame, and in the possession of the heirs of the Rev. John S. C. Greene, but was burned in the great fire in 1872 .

\section{John Greene}

The subject of this fine portrait was known as "John Greene of Boston." He was born December 24, I73 I, and married, March II, I756, Catherine, daughter of William Greene, the first Governor of Rhode Island. He died Dec. 3, I78I. The portrait is an excellent example of the late American period of Copley's work. It measures forty by fifty inches and is in its original frame. It shows the subject as seated at a table with left hand resting on a manuscript while the right hand holds a pen. The face is half turned and has a most pleasing expression. The portrait belongs to Professor Henry M. Howe of Bedford Hills, New York.

\section{Mrs. John Greene}

This portrait is a companion picture to that of $\mathrm{Mr}$. Greene which is owned by Prof. William Howe, and 
belonged to the estate of Mr. Ward. She was Catherine, daughter of Governor William Greene of Rhode Island, and was married March I I, I756. It was sold by the Merwin Sales Co. in New York in January, I9I4. The canvas measures forty by fifty inches and is signed and dated 1769. The lady is shown in a standing position, three-quarters length, holding a blue shawl in her right hand, with left elbow resting on a rock. It belongs to Messrs. R. C. and N. M. Vose of Boston.

Joseph Greene

Was a son of Thomas and Martha Coit Greene, and was born in $\mathbf{1 7 4 5 . ~ T h i s ~ p o r t r a i t ~ i s ~ e i g h t e e n ~ b y ~ t w e n - ~}$ ty-two inches, is in the original frame, and is signed and dated I767. It is a crayon, representing a young man dressed in a stone colored coat and waistcoat, into which latter his right hand is thrust. On his head is a white wig, and about his neck and wrists is handsome lace. This portrait belongs to Mr. J. Murray Forbes of Boston.

\section{Mrs. Joseph Greene}

Wife of Joseph Greene, and daughter of Benjamin and Mary Greene; a crayon representing the lady, who was a cousin of her husband, as arrayed in a delicate rose-tinted dress, edged round the neck with 
rich lace, and a mantle of fawn color, having a blue knot on the left shoulder. Her hair, which is without powder, is ornamented with small roses. The portrait is signed and dated 1767 , is in the original frame, and is believed to have been taken about the time of her marriage, when she was celebrated for her beauty. It belongs to Mr. J. Murray Forbes of Boston.

\section{Rufus Greene}

The picture is of half length and is in Copley's early manner. It belonged to William G. Prescott.

Mrs. Rufus Greene

This picture was in the possession of her great grandson, William Gardiner Prescott, and is a companion picture to that of her husband. These portraits were formerly full length, but being injured by fire, were reduced in size.

\section{Thomas Greene}

Was an eminent merchant of Boston, where he was born June 4, I705. He was the eldest son of Nathaniel and Anne Gould Greene, who came to Boston from Warwick, R. I. He married first, February 22, 1727, Elizabeth Gardiner, and for his second wife, September 6, I744, Martha Coit, daughter of John Coit, of New London, Conn., and widow of Daniel Hubbard, who died I74I. Mr. Thomas 
Greene died in August, 1763. He left five sons, Thomas, John, Nathaniel, Joseph and David, and one daughter, Mary, married to Daniel Hubbard. This portrait is forty by fifty inches, and represents Mr. Greene as dressed in a suit of drab color with black waistcoat. He wears ruffles and a large powdered wig. He is seated in an old fashioned chair by a table, on which is an inkstand, letter, etc. On the right is a green curtain drawn back, disclosing through an open window a ship under full sail flying the British flag. Mr. Greene holds in his hand an open letter bearing the date of September 25, 1758, undoubtedly the time at which it was painted. A copy of this picture belongs to Mr. C. W. Hubbard of Boston. The original belongs to David Greene Haskins of Cambridge.

\section{Mrs. Thomas Greene}

Born in New London, Conn., in I706, was Martha, the youngest daughter of John and Mehitable Chandler Coit, of New London, Conn. She married first, Daniel Hubbard, sheriff of New London, a graduate of Yale College in 1727 , a tutor in the college, and who died in $\mathbf{1 7 4 1}$, and second, in $1744, \mathrm{Mr}$. Thomas Greene. She is represented in a brown robe, trimmed with white satin, the sleeves and neck decorated with lace. Her hair is drawn back in curls, one of 
which rests upon her shoulder. The pose of the head is very erect. The eyebrows are arched, and the eyes are dark and brilliant. The background represents a landscape, with rocks and trees. The figure, which is not quite full length, is seated with one arm resting upon the back of the chair. This picture is in the possession of David G. Haskins of Cambridge.

\section{Thomas Greene and his Wife}

The picture is six inches by eight, and contains the two likenesses, of miniature size, painted in oil, on the same copper plate. The frame is of dark wood. The gentleman is in a white wig, a green coat, and a ruffled shirt. The lady is dressed in a low necked, claret colored dress of the period, with a pearl necklace, and also pearls on her stomacher and in her hair. The picture was in the possession of their great granddaughter, Miss Mary G. Chapman of Boston.

\section{Rev. Daniel Greenleaf}

We learn from Freeman's "History of Cape Cod," that this gentleman was a son of Stephen Greenleaf, of Newbury; that he was born in 1679 , was graduated at Harvard College in $\mathbf{1 6 9 9}$, and married Eliza, daughter of Sheriff Gookin, of Suffolk, and granddaughter of Major-General Gookin of Cambridge. The sub- 
ject is represented in clerical robe holding a book. The portrait was evidently painted about I 760 and measures twenty-nine by thirty-six inches. It is loaned by R. C. Greenleaf to the Metropolitan Art Museum.

\section{Mrs. Samuel Greenwood}

Mother of John Greenwood, the artist, was Mary Charnock. Her portrait by Copley, painted in $\mathbf{I} 770$ and sent to exhibition in London in I77I, catalogued as "A Lady, half length." Anderson, who saw the picture in the Lyndhurst sale describes it as an old lady leaning on a Pembroke table. Benjamin West under date of June I6, I77I writes to Copley, "Your picture of Mrs. Greenwood was exhibited and did great honor." Copley says in a letter to John Greenwood under date of January 25, I77I, "I shall be happy if the portrait that accompanys this (of your mother) is approved. I shall be impatient to hear the criticisms on it." The portrait is now in the possession of her great grandson, John Danforth Greenwood of Motucka Nelson, New Zealand.

A sketch of this picture is owned by Isaac J. Greenwood of New York City.

\section{William Gretton and Wife}

The portraits of Dr. Gretton and his wife were painted in appreciation of his services in advising 
and assisting the younger Copley at the time of his entrance to Trinity College. Dr. Gretton was born in 1736 and died in 1813 . He was Master of Magdalene College and Archdeacon of Essex in 1795.

\section{HAgar AND IshmaEL}

This picture, a companion in size to the "Abraham's Sacrifice," was exhibited at the Royal Academy in 1798 and sold at the Lyndhurst Sale in $\mathbf{I} 864$. It was engraved by Dunkarton and published by Copley in I798. It shows the seated figure of Hagar with Ishmael across her knees a landscape background. An angel is in the upper right hand corner.

\section{General Frederick Haldimand}

Born I718, died I79I. A British soldier of Swiss birth. He distinguished himself at Ticonderoga and was Governor of Canada from I778 to I785. This fine portrait was exhibited in Boston in I9I I from the collection of the Duke of Kent.

\section{Hugh Hall}

A crayon eighteen inches long by sixteen wide, dated 1758, J. S. Copley. It was in the possession of his great granddaughter, Miss Baury of Boston. 


\section{Mrss Hall}

This picture is of half length, and life size, representing a lady dressed in black velvet in the fashion of the times, the throat and sleeves decorated with rich lace. In her hand she holds a rose bud. The picture is now owned by Mr. T. B. Clarke of New York.

\section{Benjamin Hallowell}

He was a brother of Sarah Hallowell, who married Samuel Vaughan of London. He is represented as a man of about twenty-five years of age, seated at a table with books and holding a pen in his hand. $\mathrm{He}$ is dressed in a suit of gray silk with buttons, faced with satin; a white cravat and ruffles, with white silk stockings, complete the costume. The picture measures four feet one inch long by three feet three inches wide. It is in the possession of Mrs. W. M. Vaughan of Cambridge.

\section{John Hancock}

A picture of three-fourths length. He is dressed in a blue coat laced with gold. His left hand is resting on a book while his right hand holds a pen. He was born in 1737; graduated at Harvard College in 1754; was President of Congress and first signer of the Declaration of Independence; was Governor of 
Massachusetts in 1783 and died in office in 1793 . It belongs to the City of Boston and is deposited in the Boston Museum of Fine Arts.

A copy of this picture by Savage is owned by Mrs. J. W. Tilton of Haverhill.

Another picture, also owned by Mrs. Tilton, shows Governor Hancock dressed in a blue coat laced with gold.

Copley also painted a miniature which was exhibited in New York several years ago.

There is a fine portrait of Hancock in the Henry Lee mansion at Brookline.

The following bill is interesting as showing the amount Copley received for the portraits listed. The Hon'ble John Hancock, Esqr.

Boston, I765. To Jno. S. Copley, Dr.

To painting one portrait of himself, at 8 guineas I I $l .4$ To one portrait in miniature, 5 guineas $\ldots \ldots .70$ 1767. To cleaning and varnishing seven picures, at $8 \ldots \ldots \ldots \ldots \ldots \ldots \ldots \ldots \ldots \ldots$ ro 1766. To a portrait of Mr. Henchman,3/4 cloth 916 1770. To one portrait of himself $\ldots \ldots \ldots 916$ - * To do. of Doctr. Sewall, at 4 guineas ...... 5 I 2

Boston, Sept 18, I77I.

Recd. the contents in full, for Mr. Copley. . $46 l .4$ pr. Henry Pelham 
Another picture of Hancock from which a mezzotint engraving was made, shows the subject at half length, life size, with white wig, and coat and waistcoat heavily embroidered. It is an oval portrait. At the time the engraving was made the portrait belonged to Captain James Scott.

\section{Thomas Hancock}

He was born in 1703, and died in 1764; was the son of the Rev. John Hancock of Lexington, and married Lydia, the daughter of Daniel Henchman of Boston. He founded the Hancock Professorship of Hebrew and other Oriental Languages, and built the Hancock house on Beacon Street in 1737. This is a half length portrait in crayons. $\mathrm{He}$ is dressed in the style of the period. This picture belongs to Mrs. J. W. Tilton of Haverhill.

There is a full length picture, very finely painted. $\mathrm{He}$ is dressed in a black velvet suit, white gloves, and a white wig. The right hand rests on a chair. This portrait was in the possession of Harvard College.

There is another portrait three inches long by four and a half wide. It is an oval miniature in oil on copper. The subject is dressed in a pearl-colored velvet suit and a white necktie. The hair is powdered and gathered into a white queue. The face has the look of one past middle age. 
Another portrait measuring fifteen by eighteen inches, in crayon shows the subject in white wig, white neckcloth and blue coat. The face is close shaven and florid and slightly turned. It is in its original black and gold frame and belongs to Mrs. C. H. Wood of Boston.

\section{Mrs. Lydia Hancock}

This is a finely painted picture. The subject is in mourning, with a black dress, a white linen under cap and neckerchief, and a black crepe hood enveloping the head and neck. This portrait was in the possession of Harvard College.

A crayon of half length is in the possession of Mrs. J. W. Tilton of Haverhill. Mrs. Hancock died in 1777 , leaving in her will the old parsonage in Court Street to the Brattle Street Church.

\section{Mrs. John Hay}

Mrs. Hay, whose maiden name was Catherine Farnham, is represented on an oval canvas as a very beautiful woman with dark eyes, hair dressed high, with a gold bow on the top. Her dress is dark with a simple ruffle around the neck. This portrait was painted in London and is a fine example of the artist's work. It was painted in $\mathbf{I} 780$ and is mentioned in a letter from Judge Curwen, who saw the picture in 
Copley's studio. It is now in the possession of $\mathrm{Mr}$. Francis S. Cobb and lent to the Boston Museum of Fine Arts.

\section{William Hayley}

This portrait of the poet Hayley, painted in sepia, represents the subject as writing at a table. It measures twenty-six and one-half by thirty-two and one-half inches and was sold at auction at Christie's in I912. Hayley was born in 1745 and died in 1820 . He was a friend of Cowper, Romney and Souther, and published several volumes of verse.

\section{Lord HeathField}

There is a fine portrait in the National Gallery and a study head of the same officer made for the "Siege of Gibraltar" owned by Mrs. F. Gordon Dexter of Boston. There is a study head $26 \times 23$ for the large historical picture of the "Siege of Gibraltar" in the Court of the Common Council at the Guildhall, London. George Augustus Eliott was raised to the peerage in 1787 as Baron Heathfield of Gibraltar.

\section{RICHARD HEBER}

Richard Heber in boyhood is shown leaning on a cricket bat with a ball in his hand. He was born in 1773 and died in 1833 . He was the founder of the 
great Heber Book Collection. On seeing the portrait Dean Swift remarked, "If you should look at him in his boyhood through the magnifying end of the glass and then in his manhood through the diminishing end of the glass, it would be impossible to spy any difference."

\section{Daniel Henchman}

Copley painted a portrait of this gentleman for Governor Hancock in I766. He was a well known and highly respected book seller whose store was on the south corner of State and Washington Streets, Boston. The whereabouts of the portrait is unknown.

\section{Joshua Henshaw}

He was born in 1703; married Elizabeth Bill in I733; and was distinguished among the early patriots of Boston, holding many offices of trust and honor. The picture is of half length, and the dress is a brown coat and full white wig. The right hand rests upon a curtain which seems to stand upon a pillar, while the left hand holds a white glove. It is in the original frame, and belonged to Mr. Sidney W. Hayward.

\section{Joseph Henshaw}

A nephew of Joshua Henshaw, whose daughter he married. He was born in 1727 , and graduated at Harvard College in 1748. During the Revolution 
he was indefatigable with pen, speech, and money, in support of the Colonial cause. He was dressed in a blue velvet coat, with the left hand in the breast, and a full white wig. He has a very handsome, determined countenance. The portrait belonged to Mr. Sydney W. Hayward.

\section{Sarah Henshaw}

The daughter of Joshua Henshaw and the wife of her cousin, Joseph Henshaw. It is a crayon of half size. She is dressed in a salmon-colored robe, with pearls in her hair. Her left hand holds the end of a fur tippet, which passes over and falls from her right shoulder. Upon her head is a blue silk hood. The portrait belonged to Mr. Sydney W. Hayward.

\section{Henry Hill}

He was the son of Thomas and Hannah Hill; born in 1736; graduated from Harvard College in 1756; married Anna Barrett in 1762 ; and died in 1828 , aged ninety-two. This is a crayon of one half length, twenty-three inches long by seventeen wide, and is in the original frame, a companion picture to that of his wife. Mr. Hill is dressed in a coat of a sage green color, and wears a powdered wig with a laced cravat. This picture was in the possession of a Mrs. Todd of Cambridge. 


\section{Mrs. Henry Hill}

Anna, a daughter of John and Sarah Barrett, born March 8, I740, married to Henry Hill in I762. Their residence was in Summer Street. She died December 8, I822, aged eighty-two. Her portrait is a crayon of three-fourths length, measuring twenty-three inches high by seventeen wide. The dress is of light flowered brocade, with a blue mantle. Her hair is dressed with flowers, and around her neck is a pearl necklace. It belongs to the Estate of Mrs. Sarah Barrett.

\section{Mr. and Mrs. Hill}

Whose portraits in oil were taken by Copley, were the grandfather and grandmother of Edward Everett. The pictures are now in the possession of a great grandson, Sidney Everett of Boston.

\section{Joseph Sayer Hixon}

This is a miniature of a handsome man of about twenty-eight years of age, with powdered hair, a scarlet coat, and plaited ruffles. This picture is in the possession of a great granddaughter, Miss Julia P. Hixon of Brooklyn, New York.

\section{Mrs. Joseph Sayer Hixon}

Was Abigail, daughter of the Rev. Samuel Cooper. Her portrait, which is a pendant to that of her husband, represents her with powdered hair, which is sur- 
mounted with a gauze toque. The dress is cut low in the neck, which is decorated with a handsome pearl necklace; over her shoulders is a mantle of blue satin, trimmed with ermine. It belongs to Miss Julia $P$. Hixon of Brooklyn, New York.

\section{Thomas Hollis}

This is a full length picture. The dress is brown, laced with gold; the right hand holds a pen, resting on a book. Thomas Hollis was born in I659 and died in I73 I. He endowed Harvard College with the Hollis Professorship of Divinity and with a Professorship of Mathematics and Natural Philosophy. This portrait is at Harvard College, and is a copy made by Copley in I766 after an English portrait of half length. In a letter from Dr. Holyoke to Copley, under date of Cambridge, January 3 I, I769, an order is made on Copley for the delivery of the picture.

\section{Mrs. IsaAc Holmes}

She was Rebecca Bee, and married Mr. Isaac Holmes of Charleston, S. C. Her mother's name was also Holmes. Her portrait is of life size, and half length. Her dress is in the fashion of the times, of white satin, trimmed at the neck and sleeves with rich lace. Her hair is drawn back, and braided with 
pearls, and a pearl necklace encircles her throat three times. The portrait belongs to Mr. H. E. Pratt of Brooklyn, New York.

\section{John B. Holmes}

This is a half length portrait of a boy of about ten years of age, in the costume of the times, consisting of a blue coat, a red silk waistcoat, and lace ruffles at the neck and wrists. His right hand is thrust into his waistcoat pocket, and on his left arm sits a pretty squirrel eating a nut. This portrait belongs to Mrs. William Allen Putnam of New York.

\section{William Holmes}

A younger brother of John B. Holmes. The picture is of the same size as that of his brother, differing in the colors of the dress. The boy stands with one hand resting on a small greyhound. It belongs to Mr. D. M. Prouty.

\section{Holy Family}

This picture painted at Parma, Italy, by Copley after Correggio was exhibited at the British Institute in 1817 by Wentworth B. Beaumont.

\section{Edward Holyoke}

President of Harvard College. He was born in I689 and died in I769; he was especially distinguished 
as a mathematician and classical scholar. $\mathrm{He}$ is represented in clerical robes, and is seated in a chair. The picture is in Copley's early manner. It was presented to Harvard College in 1830 by Dr. E. A. Holyoke.

A second portrait represents him, as the other, dressed in a black silk robe, with white bands. The size of the picture is twenty-six inches long by twentyone inches wide. It was in the possession of his great grandson, Hon. Hampden Cutts, of Brattleborough, Vermont.

There is a third portrait in Crayon measuring sixteen by eighteen inches belonging to Mrs. Robert King of Montclair, N. J.

\section{Alice Hooper}

Of Newburyport. This picture is of three-fourths length. The figure is rather in profile, and is dressed in a dark blue satin. The hair is worn without powder. It is in the possession of Mrs. J. L. Newton.

Mr. Joseph Hooper

A son of Robert Hooper. Born 1743, Harvard College 1763. This portrait is three-fourths length, of life size, and represents the subject sitting in a rich coat of brown velvet; his left arm is over the back of a chair, and his right hand is in his coat. The 
waistcoat is embroidered with gold braid. The portrait belongs to Mr. Samuel Hooper of Boston.

\section{Mrs. Joseph Hooper}

Wife of the younger Mr. Hooper who was Mary Harris. She is shown sitting in a rich and appropriate dress of red with a black, gold braided girdle. Her right hand is holding the left hand at the wrist. It belongs to Mr. Samuel Hooper.

\section{RoBert HoOper}

Of Marblehead, Mass. The portrait is five feet long by four wide, including the frame. It represents a robust man past middle life, seated at his desk reading a letter, which is held in his left hand. The right hand rests on the desk, on which are lying several other letters. The dress is of brown cloth, with metal buttons like the court dress of Europe, and is completed by a full white wig. He was an eminent merchant, born in 1710 , and died in 1790 . On account of the magnitude of his business and his liberal character, he was known all over New England by the sobriquet of King Hooper. The portrait was painted in 1767 and now hangs in the Boston Museum of Fine Arts, lent by Mrs. Lathrop Brown. 


\section{Mrs. Robert Hooper}

The size of this picture is four feet two inches high by three feet three inches wide. It is of three-fourths length. She is represented in the full costume of the time, very rich and elaborate, and is sitting upon a small sofa. She is one of the three wives of Robert Hooper, known as King Hooper, whose beautiful house at Danvers still remains. This picture is in the Lenox Collection in the New York Public Library.

Robert Hooper, Jr.

This is a fine example of Copley's best American period. It measures forty by fifty inches, and the subject is shown three-quarters length, in a standing position. He holds a cane in his left hand and his right hand is in his coat, which is of brown material. The picture is now owned by Mr. R. H. Stevenson of Boston.

\section{Mrs. Stephen Hooper}

The following correspondence between Stephen Hooper and Henry Pelham would indicate that Copley possibly made a portrait of Mrs. Hooper. She was Sarah Woodbridge of Newburyport.

Newbury Port, I9th Sept., 1773

Sir

I could wish Our Friend Mr. Copley, had made equal Dispatch with Mrs. Hoopers Picture, as we 
want it much; however, I suppose him much hurried, as I hear he has engaged his Passage, but hope he'll finish it ere he leaves his Native Place; Mrs. Hooper joins me, in our respectfull Compliments to him, his Lady and yourself; and believe me to be your Friend Stephen Hooper.

\section{Judge Martin Howard}

There is a very fine example of Copley's art in the portrait of Judge Howard of South Carolina. It is three-quarters length and he is represented in the red robe of an English judge and wears a white wig. The picture hangs in the Social Law Library in Boston.

\section{Richard, Earl Howe}

This is a half length portrait in uniform. An engraving was made by Dunkarton in 1794 and published by Copley. Richard, Earl Howe, was born in I 726 and died in 1799 . He was Commander-in-Chief on the North American station during the War of the Revolution.

\section{LORd Howe}

A portrait of this distinguished officer, made in a small circle, was sold by the executors of Lord Lyndhurst in March, 1864 . 


\section{Daniel Hubbard}

A life sized, three-fourths length picture, the canvas being four feet and one inch in length by three feet four inches in width. He is in full dress, with powdered hair, silk stockings, a long white satin waistcoat, with wide cuffs lined with satin. There are ruffles at the wrists. This picture is in the possession of Mrs. Tudor of Boston.

\section{Mrs. Daniel Hubbard}

A companion picture to that of her husband. She is taken standing by a small table, on which one arm rests, and the other is crossed over it. Her black hair is combed back over a cushion, and around her neck is a ruff, which, according to the fashion of that time, was fastened by a bow to the hair behind. The dress is of golden brown satin, low in the neck, and decorated with lace. This picture is in the possession of Mrs. Tudor of Boston.

\section{Miss Thankful Hubbard}

The following is a copy of the bill for this miniature, but the whereabouts of the picture is unknown.

Mrs. Fayerweather Boston, May 20, 1758.

$$
\text { To J. S. Copley, Dr. }
$$

To painting a picture in miniature of Miss Thankful Hubbard, one guinea. Received the contents. 


\section{Thomas Hubbard}

This picture is of three-fourths length. $\mathrm{He}$ was born in 1702; graduated at Harvard College in 1721; and died in 1773. He was Treasurer of the College from 1752 to 1763 , and resided on Summer Street, on the site of the store of C. F. Hovey Company. The dress is a blue morning robe, with a purple cap. Near him is a table, with the keys of the College upon it. This picture is in the possession of Harvard College and was presented by Mrs. Appleton.

\section{Colonels Hugo and Schleppengull}

These two fine portrait heads on one canvas are studies for the large picture of the Siege of Gibraltar. They were sold at the Lyndhurst Sale for £Io Ios, and now belong to Mrs. F. Gordon Dexter of Boston.

\section{Miss Eliza Hunter}

This beautiful portrait is in miniature, made in England in 1784 while this lady was abroad with her sister. This lady, who lived in Newport, R. I., never married. Her sisters Katherine and Ann married abroad.

\section{Nathaniel Hurd}

He was born February 12, 1730, and died December I7, I777. He was one of the earliest resident engravers on copper in New England. He engraved 
several of Copley's pictures, a miniature likeness of the Rev. Dr. Sewall, minister of the Old South Church in 1864 , and also a representation of the Boston Massacre, the seal of Harvard University, and many other beautiful specimens of heraldic designs. The head is completed, but the rest of the picture is unfinished. It is evident, however, that Copley in-. tended to represent his friend, the engraver, characteristically at work, as the hands, and the shirt sleeves rolled up, are more than indicated. This picture is in the possession of a descendant, Nathaniel Furness of Tarrytown-on-the-Hudson.

There is another fine picture of this artist, of half length, highly finished, representing him as sitting at a table on which are two books, one being a treatise on heraldry. He is dressed in a morning robe with a cap on his head. His arms rest on the table, the hands being clasped.

\section{Thomas Hutchinson}

Was the son of Thomas Hutchinson of Boston, and Sarah, daughter of Colonel John Foster. He was born in Boston, I7II; and was a graduate of Harvard College, I727. He served as a representative seven years, and as Speaker of the House three years; was Judge of Probate in 1752, and a Councillor from I 749 to 1766. He was Lieutenant-Governor from $175^{8}$ to 
177I, and was appointed Chief-Justice of Massachusetts in 1760 , holding says Mr. Drake, "four high offices at the same time." He was appointed Governor of Massachusetts in I77I. A very able writer, a powerful orator, and an uncomprising Loyalist, he was exceedingly unpopular, and on account of his support of the Stamp Act, his house was sacked and his furniture and many valuable historical manuscripts were burned in the street. He left the country, and went to England in 1774, where he received a pension from the British Government, and died at Brompton in 1780 . This portrait is eighteen inches high by fourteen wide, and is in the original frame. It represents him as a distinguished man, dressed in a light-colored coat, and wearing a white wig. The picture is in the possession of the Massachusetts Historical Society. The following letter from Copley to Pelham evidently refers to another picture.

Dear Brother,

London, Augt. 25, 1774 .

Please to send enclosed to Gov. Hutchinson the drawing I took of him with a pencil some years since. You may if you please keep a copy of it.

I shall set out in about four hours for Brighthemstone and from thence take ship for Diepe in France etc., etc. God bless you. Your affect. Brother, John Singleton Copley. 


\section{Mrs. Thomas Hutchinson}

The portrait of Margaret Safford, wife of Governor Hutchinson, is owned by Mrs. F. Gordon Dexter of Boston.

\section{General Hyatt}

This portrait of an English general is in Copley's latest manner. It measures twenty-two inches by thirty and represents the subject dressed in the red coat of a British officer. He wears no wig but his hair is powdered. He has a buff waistcoat and his coat is trimmed with silver lace. His left hand grasps his sword hilt, which rests on a volume marked "Mil Essays." The picture belongs to Mrs. T. Jefferson Cooldige, Jr., of Boston.

Mrs. Henderson Inches

She was the second wife of Henderson Inches, and a daughter of Jonathan Jackson. The picture is of three-fourths length. It represents a lady standing in a room draped with dark green curtains. To the left is a vase, and the sky beyond. Her dress is of rose-colored satin, looped at the arms with jewels. Her right hand holds her dress back, while with her left she seems drawing on her mantle. Close under her chin is a lace tie. Her hair is without powder, with a bow on the top of her head. The picture belongs to Mrs. John Chester Inches of Boston. 


\section{JAREd Ingersoll}

This is a fine example of Copley's best English portrait work. It is of a very handsome and dignified man dressed in a rich coat of dark salmoncolored velvet, with waistcoat embroidered with gold braid. He is shown seated, holding a document folded in his right hand, with left hand resting on his knee. Mr. Ingersoll was an active Connecticut loyalist, residing in Hartford. He was sent to England with arguments intended to show the illegality of the Stamp Act. Returning with a commission as Stamp Collector, he was met on the road to Hartford by the Sons of Liberty and forced to resign his commission. This portrait is in the possession of Mr. Ingersoll Amory of Boston.

\section{Mrs. Elizabeth Inman}

She was a sister of James Murray, and with him emigrated to America in 1749. She married first, Captain Samuel Campbell; second, Mr. James Smith, of Milton, in I760; and third, Mr. Ralph Inman, of Cambridge. She died in Boston in 1785. This picture was painted in $\mathbf{1} 769$, and is forty-nine inches long by thirty-nine in width. The lady is dressed in a low necked, cinnamon-colored robe. Over her shoulders is a green scarf, and her sleeves are decorated with rich lace. Her hair is combed back over a 
cushion, ornamented with a string of pearls. In her left hand she holds a branch with peaches upon it, and a bunch of grapes. This picture is in the possession of Mrs. R. P. Rogers, granddaughter of Paul Revere, Canton, Mass.

\section{Mr. and Mrs. Ralph Izard}

This picture, now hanging in the Boston Museum of Fine Arts, was painted during Copley's visit to Rome in $\mathbf{I} 774$ to $\mathbf{I 7 7 5 . ~ M r . ~ I z a r d ~ w a s ~ a ~ w e a l t h y ~}$ planter of South Carolina, and Mrs. Izard before her marriage was Miss Alice De Lancey of Mamaroneck, New York. The figure of Mrs. Izard as she submits a sketch to her husband is full of charm but the figure of the gentleman is rather hard and stiff. The two people are seated at a handsomely carved table with drapery, with a landscape and statue showing in the background.

\section{JONATHAN JACKSON}

A noted merchant, and a descendant in the fourth generation from Edward Jackson, one of the first settlers in Cambridge, and afterwards of Newton. He was the first president of the Boston Bank, holding office from 1803 to his death in 1810 . This is a crayon portrait, and one of five portraits of him by Copley. It is on a sheet of paper, showing the face 
only, which is of life size. It is in the possession of Justice O. W. Holmes, Washington, D. C.

Another portrait in pastel belonged to Henry Lee, of Brookline, a grandson of Mr. Jackson. It measures seventeen by twenty-three inches, and was made between I76I and I773. The subject is dressed in a morning gown of green with a velvet collar.

Another portrait is an oval, eighteen by twentytwo inches. $\mathrm{He}$ is represented with a white wig, wearing a blue coat with a double row of brass buttons. The picture has a sky background. It is in the possession of Mrs. James Jackson of Boston.

Another portrait is in oil, of half size, seventeen by twenty-three inches. $\mathrm{He}$ is dressed in a loose green morning gown, trimmed with pink, a ruffled shirt, and has powdered hair. Mr. Jackson had this picture painted in 1768 , and presented it to his sister, Mrs. Wendell. It belongs to Mrs. Charles Upham of Salem, Mass.

Another picture is a half length, standing, with a landscape to the left of him. It is in the artist's latest manner, being taken in England. It was owned by his granddaughter, Susan Cabot Jackson, of Boston. 
Mrs. Jonathan Jackson

This lady was Hannah, daughter of Patrick Tracy, a very distinguished merchant of Newburyport. The portrait is a full face, the hair without powder, but decorated with a string of small pearls. It is now owned by Mrs. James Jackson of Boston.

\section{REv. JosepH JACKSON}

There is a portrait of this gentleman, who was pastor of the Church of Christ in Brookline. He was born in 1734; graduated at Harvard College in 1753; and was minister at Brookline from $\mathbf{I} 760$ until his death in 1796. The picture is owned by Mrs. Atherton Brown of Boston.

\section{Miss Jackson}

A portrait of a daughter of Dr. Joseph Jackson was made by Copley according to a bill of which the following is a copy.

1765 Dr. Joseph Jackson Esqr. To J. S. Copley,

To one Portrait of

his Daughter at

Eight Guineas

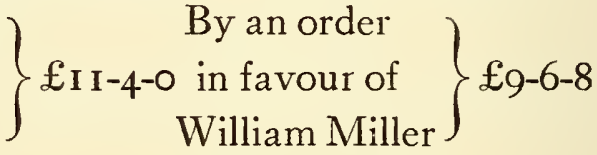
By your acct. I-I 7-4
Boston 25th March I769£iI-4-0

Errors Excepted, John Singleton Copley

The above bill is in the Chamberlain Collection in the Boston Public Library. 


\section{George Jaffrey}

This is an early example of Copley's work, measuring twenty-five by thirty inches. The subject is shown at half length and full face. He is dressed in brown coat with buttons on the cuffs, and white wig. George Jaffrey was born in I7 17 , graduated at Harvard in 1736 , and died in $\mathbf{1} 802$. He was a strong loyalist, a Treasurer and Councillor of New Hampshire, resigning his office in $\mathbf{I} 776$. This portrait belongs to Mr. William A. Jeffries of Boston.

\section{Mrs. George Jaffrey}

She was Lucy, daughter of John Winthrop. She died in I776. This is an early example of Copley's work. It is companion in size to that of her husband. She has black hair with a comb ornamented with brilliants and there are also brilliants in the trimming of her dress and a pendant on her sleeve. She wears a green velvet scarf. The portrait belongs to Mr. William A. Jeffries of Boston.

\section{Mrs. JEPHSON}

She was a daughter of Thomas Flucker, Secretary of the Province of Massachusetts, and a portrait of her by Copley is mentioned in a letter from Mrs. Urquhart to her sister, Mrs. General Knox. This letter is among the papers of Admiral Thacher. It is 
stated that she died early, and left no children. In a note from William Knox, I783, he says, "Miss Flucker is made the happy wife of a member of the Irish Parliament. Mr. Jephson is an admirable man, has a handsome fortune, besides large expectations." The whereabouts of this picture is unknown.

\section{Benjamin Johnstone}

A portrait of this gentleman, who was an early organ builder, and who married in 1770 Anne Stickney of Newburyport, is owned by Mrs. Charles S. Hanks of Brookline.

\section{William Jones}

A half length picture, representing a young man of nineteen or twenty years of age. He is dressed in a gray coat, and is in a standing attitude. The portrait was in the possession of a relation, Miss Jane Welles of Boston.

\section{Sir Edward Knatchbull's Family}

There are twelve in the group. The picture was commenced in 1800 and finished several years later. It is still in the possession of the family. It was little known owing to the unwillingness of the family to exhibit it or to have it engraved. 


\section{Judge Woodbury Langdon}

Born at Portsmouth, N. H., I739. Died there January I805. A Judge of the Supreme Court of New Hampshire, I782 and I786-90, and a brother of Governor John Langdon. The portrait was painted about $\mathbf{1 7 7 5}$, a very short time before Copley's departure. This portrait and also that of Mrs. Langdon hung in Shirley House, Roxbury, for fifty years during its occupancy by Mrs. William Eustis, widow of Governor Eustis. Prior to this time the portraits hung in the house now known as the Rockingham Hotel at Portsmouth, N. H., which house was built by Judge Woodbury Langdon as his private residence, the bricks being brought from England. These portraits also hung at Wentworth House, possibly for only a few years. Copies of these pictures are owned by Mrs. Charles S. Hamlin of Boston, and also by Mrs. Anna Parker Pruyn of Albany, N. Y., descendants of Judge Langdon, and there is one also in the Senate Chamber in the New Hampshire State House. The original picture is of life size and three-quarters length. He is standing, dressed in a rich costume of the period, being a coat of brown cloth trimmed with gold lace and a green satin waistcoat. The hair is brushed back and worn in a queue. The original portrait is owned by Woodbury G. Langdon of New York. 


\section{Mrs. Woodbury Langdon}

This is a three-fourths length picture, a companion to that of her husband, Judge Langdon. She is standing dressed in white satin with a violet scarf around her shoulders. She has lace sleeves, and her hair is brushed back. A string of pearls is around her neck, while in her arms she holds a quantity of loose flowers. Copies of this portrait are owned by Mrs. Charles S. Hamlin of Boston, and by Mrs. Anna Parker Pruyn of Albany, N. Y. The original is owned by Woodbury G. Langdon of New York.

\section{Henry Laurens}

Of Charleston, S. C. He was born in I724; was chosen President of the Provincial Congress Nov. I, I777; Minister Plenipotentiary to Holland in I779; signed with Franklin and Jay the preliminaries of the treaty of peace in 1782 ; and died in 1792 . This fine picture represents $\mathrm{Mr}$. Laurens seated in a chair, in a court dress, wearing a sword. His right hand rests upon a paper on a table. The picture was painted in London in $\mathbf{1 7 8 2}$, and an engraving of it by Valentine is now in Massachusetts Hall, Cambridge and there is also one in the Old State House, Boston. The picture was burned in Charleston, S. C., in I86I, being owned at the time by John Laurens. 
A fine half length portrait is owned by Alex. Smith Cochran of New York.

\section{Judge Peter Leigh}

In a letter dated January 7, 1763 , from Samuel Fayerweather to Copley, mention is made of a portrait of Judge Leigh. He was born in 1710 , died in 1759, and was Chief-Justice of South Carolina. His only surviving son was Sir Egerton Leigh, whose controversy with Henry Laurens gave occasion to an interesting series of pamphlets before the War of Independence. The portrait is probably still in the south.

\section{Dr. Joseph Lemmon}

He was an eminent physician, a graduate of Harvard College in 1735. He married for a first wife, a daughter of the Rev. Dr. Swett, a beautiful woman, who died young. His second wife was a daughter of General Gookin. Dr. Lemmon was the great grandfather of General William Raymond Lee. The whereabouts of this picture is unknown.

\section{Colonel Jeremiah Lee}

The father of Colonel W. R. Lee of the Continental Army. This picture is signed with a monogram, and dated 1769 . It is eight feet in length by five feet in width, and is in the original frame. It represents 
Colonel Lee standing, his left hand resting on a table and holding a letter, with his right hand upon his hip. He is dressed in a suit of brown velvet, laced with gold, and wears a full white wig. From the window there is a landscape view. The whole is painted with uncommon care. This picture, also that of Mrs. Lee, formerly belonged to the Tracy family of Newburyport, and now belongs to Thomas Amory Lee, being loaned in 1908 to the Museum of Fine Arts, Boston.

\section{Mrs. Jeremiah Lee}

Her maiden name was Martha Sweet. This is a companion picture to that of her husband, and is also signed with a monogram and dated 1769 . Mrs. Lee is represented as ascending the steps of a terrace, beyond which there is a beautiful landscape with mountains and a river. Her dress is of golden brown satin, with a mantle of blue. Over her shoulders she has an ermine cape, and in the lap of her dress she carries grapes and fruits, beautifully painted. Her eyes are black and brilliant, her hair is without powder, and her ornaments are pearls. This picture shows marks of great care and study, and is an admirable specimen of Copley's manner at that period of his life. It belongs to Thomas Amory Lee and was loaned to the Museum of Fine Arts, Boston, in 1908. 


\section{Daniel Leonard}

There is a small portrait measuring sixteen by eighteen inches of Judge Leonard of life size, but showing only head and shoulders. He was a resident of Taunton, was an ardent loyalist, and it is believed the letters signed "Massachusettensis" in the Massachusetts Gazette were written by him. This portrait now belongs to the Old Colony Historical Society.

\section{Thomas Lewis}

He was a merchant, born in Boston, November I 5 , I735, and died at Marblehead, December 21, I80I, aged sixty-six years. The dress is a long coat, with deep cuffs, a long waistcoat, trimmed with silver lace, and deep ruffles around the wrists. The position shows the head resting on the right hand, the elbow on a ledger. In the left hand is an open letter. An inkstand with pen stands on the table. This portrait is in the possession of Lewis Johnson, Plainfield, N. J.

\section{Jean Etienne Liotard}

This is a crayon portrait showing the subject in a turban with heavy black beard, sash, and elaborately ornamented vest and jacket. This portrait together with those of Mr. John Powell and Mrs. John Powell belonged to a Mrs. Warren, a member of the 
Powell family living in England. After her death her husband sent them to Eliza Powell, eldest daughter of Chief-Justice William Dummer Powell. The letter advising of the shipment says "We are sending you the three Copley pictures, etc." The three pictures are in the possession of Mr. Aemilius Jarvis of Toronto. Reference is made in the "Copley-Pelham Letters" to Monsieur Liotard in Copley's handwriting, unsigned and without address. Upon another sheet is written in a different handwriting "A Monsieur Liotard, fameux Peintre a Geneve en Suisse." Liotard, I702-I790, was surnamed "The Turk" because of his adopting the Turkish costume. Liotard is remembered chiefly for his delicate pastel drawings, of which the Chocolate Girl is one of the best known.

Lord LitTleton AND FAmily

This is a large group picture containing several portraits. It was exhibited at Manchester, England, in I857. The picture now belongs to the present Lord Littleton. The Littleton of the portrait group was William Henry, First Baron; born I724, died I808. Governor of South Carolina, I755-62.

Mrs. Judge Livermore

She was a daughter of the Rev. Arthur Browne, of Portsmouth, N. H. This portrait is owned by James H. Ford, of New York. 


\section{Mrs. John Livingston}

This portrait, measuring twenty-five by thirty inches, is in the New York Historical Society. It is in such bad condition that it is difficult to determine whether it is properly attributed to Copley. She belonged to the De Peyster family. Her dress is of brown silk, a white corsage cut low, and she wears a white lace cap.

\section{Mrs. Lloyd}

This portrait of Mrs. Lloyd as Miranda, measures twenty by twenty-four inches. It was shown at the Guildhall in 1904 and belongs to Mr. Harold Burke of London.

\section{HanNah LoRing}

Married Joshua Winslow. This three-quarter length standing figure of a handsome woman is in Copley's latest American style. It measures forty inches by fifty. She is dressed in a changeable blue silk, cut low in the neck, with elbow sleeves. Both corsage and sleeves are lace-trimmed and she wears white gloves reaching to the elbows. A bow of blue decorates the centre of the corsage and also fastens the hair in the back. She wears her hair brushed back from her forehead and is engaged in picking roses. Her right hand rests at her waist, a lace-trimmed hat 
hanging from her arm. The portrait is in the possession of Justice William Caleb Loring of Boston.

\section{The Lovers}

A picture measuring sixteen by twenty inches, attributed to Copley, was sold at Christies in London in 1909.

Judge John Lowell

Was born in 1743 , graduated at Harvard College in 1760 and died in 1802 . He was Judge of the Court of Appeals in 1783 , of the United States District Court in I789, and was Chief-Justice of the Circuit Court for Maine, New Hampshire, Vermont, and Massachusetts. He was distinguished at the bar and upon the bench. $\mathrm{He}$ is here represented in miniature, most beautifully painted, in full white wig, and blue silk figured robe. On the back of this miniature there are represented a number of trees and a temple; two angels fly over the trees holding a wreath, and in the hand of one of them is a torch. This miniature belonged to Mrs. Colonel George M. Barnard, a great granddaughter of Judge Lowell.

\section{Captain Lyde}

Who at one time commanded the ship Galen, was said to have been painted by Copley, and the portrait was in the possession of Miss Maria Lyde, his daughter, in $\mathbf{1} 866$. 


\section{Lord Lyndhurst, P.C., F.R.S., D.C.L.}

Cunningham, the English author, in "British Painters," and also Dunlap, refer to a portrait of his son, painted by Copley in I8I4. The family know nothing of the whereabouts of this portrait. John Singleton Copley, Lord Lyndhurst, was born in Boston in 1772 . In 1776 he joined his father in London. He was educated in Trinity College, Cambridge, and then entered the bar, soon distinguishing himself as a lawyer. He was knighted, and as Sir John Copley, he filled, with great credit to himself, the high offices of Chief-Justice of Chester, in I 818; Solicitor-General, in I819; Attorney-General, in I824; and Master of the Rolls, in 1826 . On the retirement of the Earl of Eldon, in I 827, he was created Baron Lyndhurst, and constituted Lord-Chancellor of England. In 1830 , his lordship resigned the Great Seal, and in 1831 was appointed Lord Chief Baron of the Exchequer. In I 834, by a change in the Ministry, he became Lord Chancellor for the second term, on which occasion, however, he retained the Great Seal but for a short time. In the year I84I, he was appointed Lord Chancellor for the third time. Lord Lyndhurst, from this period, took an active part in the legislation of the country. One of his most intimate friends was Lord Chancellor Brougham. He 
preserved his vigor of intellect to the last, and his great speech, which was on the subject of the navy of Great Britain, made in the House of Lords at the age of eighty-eight, only a short time before his death, was said at the time to have equalled, if it did not surpass, any speech he ever made. He died in 1863.

Lord Lyndhurst is represented as the Red Cross Knight, in the large picture owned by Mr. Gordon Dexter of Boston.

In the will of Georgina, Baroness Lyndhurst who was a daughter of Lewis Goldsmith of Paris, the widow of Lord Lyndhurst, she bequeathes the portrait of Lyndhurst by his father to her step-daughter, the Hon. Mrs. Sophia Clarence Beckett. Lady Lyndhurst died in London, December 22, I90I, aged ninety-four.

\section{Thomas ManN}

This picture is three feet high by two feet eight inches wide. The gentleman is represented as standing with his hat under his arm. He wears a white wig and is in the costume of the times; both hands are painted. This picture was owned by John G. Metcalf of Mendon, Mass.

\section{Mrs. Thomas ManN}

A companion picture to that of her husband. The hair is combed back, and a long curl hangs upon her shoulder. The dress, which is in the fashion of the 
times, is of a green shade; a reddish mantle passes over her left shoulder, and lies upon her lap. In her hands she holds a string of beads. It is said that the two portraits were painted as early as I753. It was in the possession of John G. Metcalf of Mendon, Mass.

\section{Lord Mansfield}

This well known picture is in the National Gallery in London. William Murray, first Earl of Mansfield, was born in 1705 and died in London in I793. It is a full length portrait, seated, in full robes of office. He holds a roll of manuscript in his left hand and his right hand rests on a table. There is an interior of a room as a background.

\section{Judge Henry Marchant}

He was born in 174I; LL.D. of Yale College in I792; and died in I796. He was Attorney-General of Rhode Island, an ardent patriot, a member of Congress, and Judge of the United States Supreme Court. The picture, painted in I79I, is oval in shape. His right hand is open and held against his left breast. The portrait is owned by Frank E. Marchant of West Kingston, R. I.

\section{Mrs. Henry Marchant}

A portrait of this lady, who was Rebecca Cooke, a companion picture to that of her husband, is owned by Frank E. Marchant of West Kingston, R. I. 


\section{Mars, Venus and Vulcan}

This allegorical picture by Copley measures twentyfive by thirty inches. Vulcan with his anvil and forge, seems engaged in making darts, one of which Venus throws at Mars. The picture is signed and dated $\mathbf{r 7 5 4}$, and at one time belonged to Mrs. H. B. Chapman of Bridgewater, Mass., and has been exhibited at the Boston Museum of Fine Arts.

\section{Colonel Thomas Marshall}

Who commanded the Tenth Massachusetts Regiment at Valley Forge. He was one of the Selectmen of Boston when the town was invested by the troops under command of General Washington. He at one time commanded at Castle Island, now Fort Independence. The size of the portrait is five feet long by four wide. It is full length, representing Colonel Marshall seated. The costume is a brown velvet suit of the time. It is in the possession of the family.

\section{Mrs. Thomas Marshall}

Was a daughter of Mr. Allen, of Gloucester, and was the second wife of Colonel Thomas Marshall. Her dress is white satin, in the fashion of the times, the bodice and sleeves decorated with lace. Her hair is drawn back over a cushion, and ornamented with 
flowers and lace. This picture was owned by John L. Hayes of Cambridge.

\section{Flora MacDonald}

Celebrated for aiding in the escape of Charles Edward, the Young Pretender, born South-Uist, Scotland, I720; died March 4, I790. Daughter of MacDonald of Milton. In I750 she married Alexander MacDonald, with whom she came to North Carolina in $\mathbf{1 7 7 3}$, and settled in Fayetteville. He was a captain in the Loyal Highlanders; and, after experiencing reverses of various kinds, they returned to Skye, Scotland, before the end of the Revolutionary War. She gave a proof of her courage during an attack on the ship while on the voyage home, taking part in the action, in which her arm was accidentally broken. Two of her sons were Loyalist officers in the Revolutionary War. One of them, John, an accomplished scholar, lieutenant-colonel, and a fellow of the Royal Society, died August I6, I831, aged 72. This portrait was owned in Foxboro, Mass.

\section{Mrs. MacPheadris}

The size of this picture is fifty inches long by thirtynine wide. She was Sarah, a daughter of Governor John Wentworth, and married the Hon. Archibald Macpheadris, a member of the King's Council in I724. She is represented as sitting, one arm resting 
upon a table. She has a dark complexion, dark hair and eyes, and presents a very spirited countenance. Her dress is of brown satin, ornamented with jewels and laces. This picture hangs in the house built by Archibald Macpheadris in $172 \mathrm{I}$, where it has been ever since it was painted. It is in the possession of a descendant, Miss E. Sherburne of Portsmouth, N. H.

\section{Mrs. Marryat}

The mother of the novelist. A portrait is said to be in the possession of the family in England.

\section{Judge Nymphus Marston}

Was born at Marston Mills, in $\mathbf{1 7 2 8}$, graduated at Yale College in 1749, and died in Boston, while in attendance as a delegate for the ratification of the Federal Constitution, in $\mathbf{1 7 8 8 . ~ J u d g e ~ M a r s t o n ~ w a s ~}$ noted for his learning and patriotism and was one of the principal landowners in Barnstable County. He was often called upon and did make large advances towards the expenses of the war, as the receipts among his papers show. The portrait is of full length, in a sitting position. The dress is velvet, laced with gold, and silk stockings. The right hand, holding a pen, rests upon a table. This fine picture was in the possession of his descendant, George Marston, a distinguished lawyer of New Bedford, Mass. 


\section{Colonel Joseph May}

This picture measures nine inches by twelve. It represents a young man dressed in a dark green silk coat, the hair drawn back and tied. It is in the possession of Mrs. F. A. Pratt of Concord, Mass.

\section{Rev. Jonathan Mayhew}

This was a crayon of half size. The subject was represented as dressed in robes with a white wig. $\mathrm{He}$ was a prolific writer, an associate of Otis and other patriots of the day, and renowned for great learning and ability. He was born in 1720 , graduated at Harvard College in I744, was pastor of West Church, Boston, from 1747 to his death, received the degree of S.T.D. from Aberdeen in 1749, and died July 9, 1766. This picture was destroyed in the great fire in Boston in November, 1872.

\section{Mrs. Jonathan Mayhew}

Whose maiden name was Elizabeth Clarke, daughter of Dr. John Clarke. It was a three-fourths length portrait. Although a belle of the times, she married the Rev. Dr. Mayhew. The dress was a white satin robe, with a blue mantle and hat. In her right hand she carried a rosebud, while in her left she held a basket of flowers. This picture was in the possession of her grandson, Peter Wainwright, but was destroyed by the great fire in Boston in 1872 . 
Dr. Alexander McWhorter

This portrait, painted in 1769 , measures twentyfive by thirty inches, is in the permanent collection of the Yale School of the Fine Arts, New Haven. He was born July I5, I734 and died July 20, I807. Graduated at Yale College, Class of I776. Served near Newark, N. J., in I759. Employed in a Mission to North Carolina an I764-6 and in I775 was sent by Congress to persuade the loyalists of that state to adopt the patriot cause. Chaplain to Knox's brigade in 1778 .

\section{Mrs. Alexander McWhorter}

This is a companion portrait to that of her husband, and also is in the Yale School of the Fine Arts. A copy of the bill for these two portraits is shown with that of Mrs. Bacon.

\section{William Merchant}

Was born in 1752 , and was one of the four young men who were attacked by the soldiers of the British Regiment, just previous to the Boston Massacre, the three others being Edward and Francis Archibald and John Leach. Mr. Merchant was also one of the number of the famous Tea Party. He was the son of William Merchant and Sarah Dennie. The portrait is of a child some five years of age, and 
is of life size and of more than half length. $\mathrm{He}$ is dressed in a gray coat and blue waistcoat, and has a black ribbon around his neck, with a hat under his arm. This picture was painted about 1757 , and came through Chief-Justice Richardson, of New Hampshire, a great nephew to Mr. French, of Concord, N. H. It has always been in the family.

A small portrait in Copley's early manner represents William Merchant at the age of six years. It belongs to the estate of W. M. R. French, Chicago.

\section{Thomas Mifflin and His Wife}

The portrait of Governor Thomas Mifflin and his wife, Sarah Morris, on one canvas measuring fortyseven by sixty inches is in the Historical Society of Pennsylvania. It shows a thin, angular man, with powdered hair, gray clothes, seated with his wife at a table. His forefinger is between the pages of a book. Mrs. Mifflin is engaged in making a white fringe on a mahogany frame. The picture was a bequest of Mrs. Esther F. Wistar. Governor Mifflin was born in $\mathbf{I} 744$ and died in $\mathbf{I} 800$. He was Governor of Pennsylvania from I79I to I 800 .

\section{William Shearer Miller}

Was born near Londonderry, N. H., about I723. He became a successful merchant of Salem, Mass., 
and later of Boston, but being a staunch Loyalist, he removed with his family to Jamaica, W. I., in I776, at the outbreak of hostilities in this country. This is a miniature portrait, painted on ivory, and was executed for Miller as a wedding present to his daughter, Abigail, who was married in 1770. Paul Revere's bill for furnishing the gold locket which contains this portrait, is believed to be still in existence and in the possession of one of Miller's descendants in Jamaica. The portrait is beautifully painted. It is owned by Frederick J. White of Manchester, Mass.

\section{Monmouth Before James II}

This is a large, but very unfinished example of Copley's historical pictures, representing Monmouth refusing to give the names of his accomplices. It was in the Lyndhurst Sale in 1864 and exhibited in this country in 1914.

A sketch for the picture is owned by Lord Aberdare of London.

\section{Mrs. Mary Elizabeth Montague}

A portrait of this lady was sold at Christie's in London at auction in 1903 and evidently another portrait measuring eighteen by twenty-five inches was sold at the same place in 1907 and again in 1908 to a buyer by the name of Ogilvie. 


\section{Mrs. Montague and Robert Copley}

In a letter to her daughter Mrs. Greene, in I804, Mrs. Copley mentions these portraits as having been painted on one canvas. The picture was exhibited in the Royal Academy in I804. Mrs. E. H. Harriman owns a picture which corresponds to this title, said to be by Copley.

\section{LORd Dorchester}

This portrait of Colonel Guy Carleton, afterward Baron Dorchester, was sold at Christie's, London, in 1908 . He was born in 1724 and died in 1808 , was Governor of Quebec in 1775, defeated the Americans at Champlain, October, 1776, was Commander-inChief in America in 1782, and was created Baron in 1786.

\section{The Arrest of a Conspirator}

A drawing in water color measuring twenty-five by thirty inches of this subject was sold at auction in London in 1902.

\section{Mrs. Monte Montesque}

She was Margaret Schoolcraft and married first Col. Montesque and second Crean Bush. The whereabouts of the portrait is not known.

\section{Major Montgomery}

A portrait of this officer was shown at the Royal Academy in 1780 . 


\section{Sir Jonathan Mountfort}

This is a fine example of Copley's English portraiture. It is owned by Miss Nancy M. Sanborn of Detroit, Michigan.

\section{Sir John MoOre}

This is a fine example of Copley's English portraits. This picture measures twenty-five by thirty inches, and shows head and shoulders, the body turned slightly to the left, and the head turned threequarters to the right. He is dressed in the red coat of the British with the epaulets of his rank. His hair is gray and he wears a black stock. Sir John Moore, a distinguished English General, was born i76I, and was killed in battle at Corunna, Spain, I809. $\mathrm{He}$ commanded numerous expeditions, one to the West Indies in $\mathbf{I} 798$ and to Ireland during the rebellion of the same year; to Holland in I799; to Egypt in $\mathbf{I} 80 \mathrm{I}$ with Abercrombie; and he served in Sweden and Sicily in $\mathbf{I} 808$. He received the decoration of the Order of the Bath and was known to all for his resourcefulness and his valor. Monuments to his memory were erected on the field of battle where he met his death, and in St. Paul's Cathedral. See Wilkie's poem, "The Burial of Sir John Moore," also Greene's "History of the English People." The portrait belongs to Robert H. Thorne of Chicago. 
Hon. James Murray

Was born August 9, I7I3, the son of John Murray, and grandson of Sir James Murray, of Philipshaugh, who was also heriditary Sheriff of Selkirkshire and Lord Register, in I706. This James Murray emigrated to North Carolina in $\mathbf{1 7 3 4}$, and there became a planter and a member of the Council; thence he removed to Boston in 1765 and remained until $\mathbf{1 7 7 6}$; from whence, being a Loyalist, he retired to Halifax, where he died in 178I. He left two daughters, Elizabeth, who married Edward Hutchinson Robbins and, Dorothea, who married the Rev. John Forbes. This picture was painted in I769 when Mr. Murray was fifty-seven years of age. It is fortynine inches high by thirty-nine in width. The figure is of life size, seated in an armchair. The dress is of black velvet lined with white satin ruffles, and a full wig. In his right hand, which rests upon a table covered with red cloth, is a parchment scroll. The picture is in the possession of Mr. James Murray Howe of Brush Hill, Milton.

\section{Colonel John Murray}

Of Rutland. A three-quarters length portrait, four feet, one inch long by three feet, three inches wide, representing a gentleman seated. The left hand, which holds a letter, rests on a table, on which 
are books. The right arm is akimbo. The coat and waistcoat are of a dark peach color, laced with gold. The small clothes are of black velvet with knee buckles. The wig is of iron gray. White silk stockings, white cambric ruffles and neck-cloth complete the costume. The picture is in the original frame, probably made by Paul Revere, and is owned by J. Douglas Hazen, St. John.

\section{Mrs. Colonel John Murray}

Her maiden name was Lucretia Chandler, a daughter of Judge John Chandler, of Worcester. Being a celebrated beauty of the time, she sat three times to Copley.

One picture was owned by the Rev. John Singleton Copley Greene, and represents Gardiner Greene, his father, who was also her nephew, as a boy standing by her side. This picture measures four feet in length by three feet three inches in breadth, and is signed and dated I763. It represents Mrs. Murray standing, leaning with her left arm resting on the sill of an open window. Her right hand is lightly clasping her left wrist. The dress is of brown satin, cut square in the neck, with open hanging sleeves. Both neck and arms are trimmed with rich lace. Her hair is combed back from her forehead over a high cushion, and falls in long curls upon her shoulders. 
This beautiful picture was in the possession of a great great niece, Mrs. John Ware, of South Lancaster, Mass.

\section{Rev. John Murray}

There is a pastel portrait in Copley's early manner of the Rev. Mr. Murray, who was pastor of the Old South Church at Newburyport, Mass. He was born at Antrim, Ireland, in $\mathbf{1 7 4 2}$ and died at Newburyport in 1793 . The picture is in the Newbury Historical Society.

\section{Mrs. John Murray}

The wife of the Rev. John Murray, was Judith, a sister of Governor Sargent. Born May 5, I75I. Died June 6, 1820. She married for her first husband, John Stevens. The picture is of half length and life size, representing a very handsome woman, richly dressed. Mrs. Murray was an authoress, and published both poetry and dramas. This is a very fine specimen of Copley's manner, and is owned by Charles S. Sargent, of Brookline.

\section{The Nativity}

This picture was one of the earliest pictures exhibited at the Royal Academy, being shown in $\mathbf{1 7 7 7}$. It was sold at the Lyndhurst Sale in 1864 . 


\section{Head of Negro}

A very fine finished portrait of a negro, introduced into the painting of "The Boy and the Shark" was sold at the sale of Lord Lyndhurst's pictures.

\section{LORD NELSON}

In a letter from Mrs. Copley to her daughter under date of August 23, 1806, mention is made of a portrait of Nelson. A painting of "Death of Nelson at the Battle of Trafalgar" was attributed to Copley and sold at auction in I9I3.

\section{Neptune}

This is an allegorical picture, forty-four inches long by twenty-seven wide, representing the god, who holds a trident in his right hand, and a globe in his left. He is borne upon a shell by Nymphs and Tritons. To the shell are attached four sea horses, who seem to be guided by a Cupid flying above them, holding a dart. A Triton blowing upon a conch shell brings up the rear. This picture was in the possession of Miss Simpson of Boston, who inherited it from her father, Jonathan Simpson, in whose possession it was before Copley left America.

There was another smaller picture of the same subject, reversed in position. 


\section{JoHn NEWTON}

A half length picture of life size, the canvas measuring two feet three inches long by two feet wide. He was Surveyor of his Majesty's Customs in Halifax, N. S., and was a grandson of the Hon. Thomas Newton, to whose memory a mural tablet is placed in King's Chapel, Boston. The portrait was painted in Boston in 1772 , and the date and name of the artist are inscribed in a shady corner of the picture. It is in very good preservation, and represents a person of perhaps fifty years of age, of portly figure and dark complexion. It was accounted a perfect likeness. The dress is a coat and waistcoat of lead colored cloth, both single breasted, and trimmed with gold braid an inch wide. The hair is combed back and tied behind. The picture was in the possession of Mrs. E. A. Newton of Pittsfield, Mass.

\section{LORD North and Lady North}

Lord North, eldest son of the Earl of Guilford, entered the English Cabinet at the age of thirty-five and remained for fifteen years, during the most critical period in English history. He was always a favorite of the King and a recognized leader. He never understood the claims of the American people and favored a mistaken policy throughout the War of 
the Revolution. It is said that Lord North and Lady North had the unenviable reputation of being the ugliest couple in England.

\section{LORd Northampton and Son}

A portrait of Lord Northampton and his son, Lord Compton, on one canvas is said to be in England. A portrait of Lord Northampton was exhibited at the Royal Academy in I803. It is noticed by Mrs. Amory in her life of the artist.

\section{Nun With Candle}

A picture with this title is mentioned in a letter from Dr. Myles Cooper to Copley in I768. It is in the College Library of Columbia University.

The Offer of the Crown to Lady Jane Grey

This large and important picture contains eight figures, among which are the portraits of the Dukes of Northumberland and Suffolk, and other deputies of the Privy Council. The original picture was painted for Mr. Alexander Davison; it was exhibited in 1808 at the Royal Academy, and was sold at the Lyndhurst Sale in I864. It is now owned by Mrs. F. Gordon Dexter of Boston. 


\section{Dr. John Ogilvie}

Copley painted a portrait of Dr. Ogilvie in New York in $\mathbf{1 7 7 3}$. He was born in New York in $\mathbf{1 7 2 2 ,}$ graduated from Yale in 1748 , and after working as missionary to the Indians and chaplain of a regiment during the French and Indian War, was appointed in I764 assistant minister of Trinity Church, New York. He died November 22, I774. The picture is life size, to the knees. He is seated at a table on which is an open Bible. He wears a full white wig and gown. The portrait is now in the possession of Trinity Church, New York. It is mentioned in the Copley-Pelham correspondence.

\section{Hon. Andrew Oliver, Jr.}

Was born in I73I, graduated at Harvard College in 1749 , and died in Salem in I799. He married the eldest daughter of Chief-Justice Lynde, was one of the Judges of the Court of Common Pleas for Essex, and the author of an "Essay on Comets." The picture is four inches long by four wide, representing Judge Oliver in a light gray coat and full wig. It is owned by Mrs. George F. Crane, nee Oliver, of New York.

Lieutenant-Governor Andrew Oliver

Was born in 1707 , graduated at Harvard College in $\mathbf{1 7 2 4}$, was Lieutenant-Governor in $\mathbf{1 7 7 0}$, was a 
determined Loyalist, and died in Boston in $\mathbf{1 7 7 4 . ~} \mathrm{He}$ is represented in a brown coat and full wig. This is a companion picture to the portrait of Judge Oliver, and is also in the possession of Mrs. George F. Crane of New York.

A very small miniature in oil of Andrew Oliver, is in the Boston Museum of Fine Arts, lent by Mrs. Susan L. Oliver. The subject is represented in white wig and white neck cloth and black coat.

\section{Daniel Oliver}

A brother of Andrew Oliver. Daniel Oliver died young. This picture is a miniature, in the possession of Mrs. George F. Crane, nee Oliver, of New York.

\section{Chief-Justice Peter Oliver}

He was a brother of Lieutenant-Governor Andrew Oliver and was Chief-Justice in I77I. He was a Loyalist and distinguished as a writer, orator and poet. He was born in $17 \mathrm{I} 3$, graduated at Harvard College in 1730 , received the degree of J.C.D. from Oxford University in 1776 , and died in England in 179I. This picture is an oval miniature, on copper about five inches long by four inches wide, and represents Judge Oliver in a brown coat and full wig. He married in 1733 a daughter of William Clarke. This picture is in the possession of Mrs. George F. Crane of New York. 


\section{Oliver}

There are said to be two portraits of the Oliver family that were at Middleborough, Mass. Their present whereabouts are unknown.

There is in the Boston Museum of Fine Arts, lent by Mrs. Susan L. Oliver, a miniature of a son of Andrew Oliver. It is in oil, evidently made on copper with a dark wood frame, oval in shape. It represents the subject in white wig, drab coat, white neck cloth, and waistcoat bordered with red. His face is nearly full front.

\section{Col. James Otis}

Colonel Otis was born in 1702 and died in 1778 . He was the father of James and Samuel Allyne Otis. The picture is forty by fifty inches in size, and the subject is shown life size in a sitting posture and nearly full face. The costume is entirely black with the exception of muslin ruffles on the sleeves. $\mathrm{He}$ wears a white wig and holds an open book in his left hand which is resting on his knee. The portrait belongs to Mr. Harrison Gray Otis of Needham, Mass.

\section{Mrs. James Otis}

She was Mary Allyne, born I702. The picture is companion in size to that of her husband. The dress 
is of light gray material with lace at sleeves and on the scarf over her shoulders. She is seated in a red back chair nearly full face. A white scarf is held in her right hand which is resting on the arm of the chair. Her left hand is holding a book. The portrait belongs to Harrison Gray Otis of Needham.

\section{Mary Otis Gray}

A daughter of James Otis, of Barnstable; a sister of James Otis, the Patriot; of Samuel Allyne Otis, the father of Harrison Gray Otis; and of Mercy Otis, who married James Warren. Mary Otis married John Gray. The picture is of three-fourths length, and was painted in 1757 . She is dressed in blue satin, with lace and pearl ornaments about the waist and in the hair. A scarf or robe hangs from the left shoulder. This picture is owned by Pelham W. Warren of New York.

\section{Mrs. Samuel Allyne Otis}

She was Elizabeth Gray. The picture measures twenty-seven by thirty inches. She is shown in a blue dress with white sleeves; her hair is dressed high, adorned with flowers, and she holds with right hand a shepherd's crook over her shoulder.

The picture belongs to Mr. Harrison Gray Otis. 


\section{Rev. Jonathan Parsons}

Born November 30, 1705 and graduated from Harvard College in 1729. Was minister of the First Presbyterian Church in Newburyport, and celebrated for his virtues, his learning and his eloquence. $\mathrm{He}$ wears a large white wig puffed at the sides, a black silk robe and bands, and holds a Bible in front of him. The picture shows only the head and shoulders. The features are strong and prominent. A copy of this painting hangs in the Old South Church, Newburyport, Mass. The original is in the possession of his great grandson, H. E. Parsons, of Ashtabula, Ohio.

Mrs. Colonel William Paxtell

This picture is in the De Peyster collection in the New York Historical Society. She was the daughter of Abraham De Peyster, Ist. The size of the canvas is forty by fifty inches. She is dressed in blue silk, and white corsage cut low at the neck and trimmed with lace. There are three rows of pearls encircling the neck. She wears short sleeves trimmed with lace and a white lace cap. A landscape background shows the rays of the sun.

\section{Major Pierson}

A small size, full length portrait of Major Pierson is in the possession of Lord Aberdare at his London house. 


\section{Charles Pelham}

The size of this picture is thirty-six inches long by twenty-eight wide. The dress is a drab coat and flowered waistcoat. A table stands in the background. Charles Pelham was born in London, $\mathbf{1 7 2 2 .}$ Baptized at St. Pauls, December 9, I722; a schoolmaster at Medford, and married Mary Tyler of that town, niece of Sir Wm. Pepperell, and was a halfbrother of Copley. The picture is the earliest one known by the artist, he being at that time not far from fourteen years of age. The coloring is quite good but the background is somewhat out of drawing. It is now owned by C. P. Curtis of Boston.

\section{Henry Pelham}

He was the half-brother of John Singleton Copley, born 1749, died 1806, and this portrait, well known as "The Boy and the Squirrel," was selected to be sent to England, for exhibition at Somerset House. The letter did not arrive until too late. Mr. West, to whom it was consigned, knew it to be the work of an American artist, from the squirrel, and also from the wood on which the canvas was stretched. The rule was to admit no pictures without the artist's name, but on this occasion it was dispensed with; and Mr. Copley was advised to go to England in consequence of the favor with which the picture was 
received. The boy is seated at a table, his right hand holding a chain to which the squirrel is attached, who sits on the table cracking a nut. A glass of water is near him. The boy is dressed in a dark blue coat with a red collar, and a yellow waistcoat; a white collar, and frills at his wrists; there is red drapery behind. The picture is thirty inches long by twenty-four wide, and is in the possession of Frederic Amory of Boston.

An unfinished portrait of Henry Pelham is owned by Mrs. F. Gordon Dexter of Boston.

A drawing of Henry Pelham is owned by $\mathrm{Mr}$. Henry Pelham Curtis.

\section{Peter Pelham}

This is a representation of the artist engraver who married the mother of John Singleton Copley. It is a life size, half length figure seated at a table on which are engraver's tools. The right arm is resting on the table, the hand holding an engraver's glass. The left hand is resting on the knee. He wears a drab coat and flowered waistcoat. This portrait belongs to Mr. Charles Pelham Curtis of Boston.

\section{The Three Pelham Children}

This large picture measuring fifty-eight by eightyeight inches is an upright canvas showing three 
children gathering apples. The boy on the lower limb of a tree is dropping fruit to two young girls standing beneath. One of the children is holding her apron to catch the fruit. It was sold in London at auction in 1902 and was brought to this country but its present whereabouts is unknown.

\section{Pepperell Family}

Copley painted a picture of the Pepperell family, the baronet, his wife, son and three daughters. It is at Wanlip Hall, Leicester, England.

\section{Lady Pepperell}

She was the wife of Sir William Pepperell. The portrait measures twenty-eight by thirty-six inches. "It is a fine specimen of the best of Copley's art, and represents her in the prime of life, arrayed in a rich silk gown, with trimmings of lace. It is a charming face, according well with the records preserved of her life." This portrait was given by Mary Pepperell Sparhawk Cutts (Mrs. Hampden Cutts) a direct descendant of Sir William Pepperell to David E. Wheeler, the father of Everett Pepperell Wheeler, the present owner.

\section{Sir William Pepperell}

A companion portrait to that of Lady Pepperell, belonging to Mrs. Mary Wheeler Smith, was unfortunately destroyed by fire. 


\section{Sir William Pepperell}

This is a pastel portrait of the younger Sir William Pepperell, who died in London in $18 \mathrm{I} 6 . \mathrm{He}$ is dressed in a blue coat with lace at the throat. The date of this picture is unknown, but it was probably made before Sir William went to Nova Scotia in I775. It measures fourteen by sixteen inches, was formerly owned by Miss Harriet Sparhawk of Portsmouth, N. H., and now belongs to Everett P. Wheeler of New York.

\section{Wilitam Pepperell and His Sister}

William Pepperell, the son of the second Sir William Pepperell and Elizabeth Royal, his wife, was born in the family mansion, but was taken to England with his sisters in 1774 . It was hoped that he would live to inherit his father's title, but he died at the Isle of Wight in 1809 , unmarried. The picture represents him as a youth standing in a park; by his side is his sister, Elizabeth Royal Pepperell, afterward married to the Rev. Henry Hutton. This picture was painted in England, and afterwards sent to this country, to Mr. Sparhawk, by whom it was presented to the Portsmouth Museum, from whom it was bought by Henry Wadsworth Longfellow, of Cambridge, in whose family it now remains. 


\section{Mrs. Edmund Perkins}

Was Esther, daughter of William and Esther Frothingham, of Charlestown. She was born in I695 and married Edmund Perkins in 1722. She was, the grandmother of James Perkins, Thomas Handasyde Perkins, Samuel G. Perkins, and of their sisters, Mrs. Russell Sturgis, Mrs. Robert Cushing, Mrs. Ralph Bennett Forbes and Mrs. Benjamin Abbott. The picture is of half length, representing an old lady dressed in a white cap, with black trimmings and a white shawl. The countenance is remarkable for the thoughtful charm of its expression, wonderfully rendered, and its fine intellectual character, age as yet not having destroyed the original regularity of the features, which in youth were said to have been of great beauty. It was made in $\mathbf{I 7 6 6 . ~}$ The tradition is that it was painted by Copley for her stepson, Henry Perkins. It is owned by Lawrence Shillaber Fuller.

\section{Mary Winthrop Phillips}

A beautiful example of Copley's work in pastel. The subject is shown as a child with flowers in her hair and a basket of fruit in her hands. The portrait is in the possession of Fred C. Weld of Lowell, Mass. 


\section{Colonel Benjamin Pickman}

This picture is of life size, measures four feet two inches long by three feet four inches in width. Colonel Pickman was born at Salem, November 18, 1740, and graduated at Harvard College in 1759. He was a merchant and spent some years during the Revolutionary War in England. Colonel Pickman is referred to by John Adams while there, as "the agreeable Mr. Pickman." He returned to Salem at the close of the war, and held important offices in the town until near the end of his life. He married Mary Toppan, daughter of Bezaleel Toppan, and granddaughter of the Rev. Christopher Toppan of Newbury, in 1762. Colonel Pickman died May 12, 1819. In the portrait he appears in a dark slate colored suit, with a red waistcoat. The coat is cut single-breasted, with large pockets in the skirts, and buttoned at the waist with two buttons and at the throat with one. He stands with one hand resting on a book, and the other on his hip. The portrait is owned by Senator Wetmore of Rhode Island.

\section{Mrs. Benjamin Pickman}

In her portrait she appears in a blue satin dress, with low neck and short, wide sleeves. The whole is deeply trimmed with white lace. She has a small bouquet on her head, put above the forehead, and 
bears in her hand a large, open parasol. The picture is a very striking one, the drapery being particularly fine. On a pillar, against which Mrs. Pickman stands, is inscribed, J. S. Copley, ז762, which is also the year she was married. The portrait is owned by Senator Wetmore of Rhode Island.

\section{Sir Thomas Picton}

General Sir Thomas Picton, the subject of this portrait which hangs in the Public Library of Malden, Mass., was the younger son of Thomas Picton of Poyston, Pembrokeshire, England, where he was born in 1758 . In 1774 he went to the West Indies as Captain in the Seventeenth Fort and was promoted to Major. He was made Governor of Trinidad and in I8or became a Brigadier-General. He commanded an army under Wellington in the Peninsular and afterwards served at Waterloo where he was killed.

\section{Pierpont}

The picture represents a child of this family, about four years old, sitting upon the floor and caressing with its left hand a spaniel dog. The eyes are dark, but the hair, which is partly covered by a cap, is light. The dress is white, and one leg, which is bare from the knee down, is very well drawn. The portrait is thirty-three inches long and twenty-six inches 
wide, and was in the possession of a descendant of the family, Mrs. William Vincent Hutchings of Roxbury.

\section{William Pitt}

Copley painted William Pitt, second son of the Earl of Chatham, born I759, died I806. It was engraved by Bartolozzi, in $\mathbf{1} 789$.

The portrait shows the subject at twenty years of age, half length, in academic gown. It is oval in shape.

\section{The Right Honorable William Ponsonby}

This portrait of the Earl of Besborough, Viscount Duncannon and Baron of Besborough in the Kingdom of Ireland, was engraved by Dunkarton and published by Copley from an original portrait in the possession of the Earl of Clanbrassell. It represents the subject seated in an elaborately upholstered chair, with the head in profile and the right hand raised with forefinger resting against the chin. The left hand rests on a book on a table. An urn is in the background on the left of the picture, with a brocaded drapery on the right.

\section{Mrs. Anna Dummer Powell}

Was the wife of John Powell, of Boston, daughter of Jeremiah Dummer, a silversmith in Boston, and 
sister of Governor William Dummer. In the family records she is sometimes referred to as "Anne" and sometimes as "Susan." She was born in I684, married to John Powell in I7I4, and died in 1764 . The picture is of life size, and three-quarters length, representing a lady in extreme old age, sitting in a large easy chair, covered with velvet. She is dressed in black satin and has a white muslin cap. A square white handkerchief is crossed in front around her neck. One hand holds a book and the other hangs over the arm of the chair. The picture is carefully painted, and the characteristics of old age are well brought out. It is in the possession of Miss A. P. Rogers, of Boston, and a duplicate is owned by Francis C. Loring. Following is a bill for the picture.

Jeremiah Powell, Esq. To J. S. Copley

To painting Your Mamma's portrait at eight Guineas

To a Gold frame for Do. at four pounds

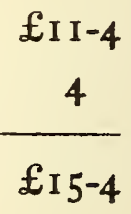

Recd. the Contents in full

Pr. J S. Copley

April 19, I764 


\section{John Powell}

A merchant of Boston, born 1716, died 1794, the son of John Powell and Susan Dummer Powell. This is a fine crayon, half length, showing the subject with white wig, face slightly turned. It measures twenty by twenty-five inches. John Powell married Janet Grant. They had a son, William Dummer Powell, a Loyalist, who emigrated to Quebec and then to upper Canada, being the first Judge of the King's Bench, and subsequently the Chief-Justice of the Province. He had a daughter, Mary, who married Samuel Peter Jarvis, who had a son, William Dummer Powell Jarvis, who had a son, Aemilius Jarvis, now living in Toronto, Canada, to whom the portraits of Mr. and Mrs. Powell belong. There is evidence that there was also a portrait in oil of John Powell as Copley sent to England a portrait of Mr. Powell in 1767 for Exhibition. Its whereabouts is unknown.

\section{Janet Grant Powell}

She was the wife of John Powell and this is a companion crayon portrait to that of her husband. She is in a low cut, lace-trimmed dress, with four rows of beads around her neck and a rose in her hair. She was a very beautiful woman and this is a charming portrait. It belongs to $\mathrm{Mr}$. Aemilius Jarvis of Toronto, Canada. 


\section{"The Three Princesses"}

Represents one of the Princesses holding over her head a tambourine, another sitting in a carriage, and a third behind the carriage. There are parrots in a grape vine overhead. The picture measures seventyone by one hundred and two inches. It was exhibited at the National Gallery in 1785, was engraved by Bartolozzi and published by Copley in $\mathbf{1 7 9 2 . ~ T h e ~}$ portraits are of Princesses Mary, Sophia and Amelia. It belongs to the King of England and hangs in Buckingham Palace.

There is a highly finished sketch for this picture which sold at the Lyndhurst Sale in 1864, and now belongs to Mr. Robert Treat Paine, 2d, of Boston. It was the habit of the artist to paint and highly finish in oil a small picture of any great work he proposed to undertake, and rarely is there any divergence from the first treatment of the subject.

\section{Josiah Quincy}

Of Braintree, was painted by John Singleton Copley in 1769. It is a half length portrait and represents Mr. Quincy at the age of sixty years, in the dress of the period; a powdered wig, a claret-colored coat and waistcoat with wrought gold buttons, a plain cravat, tight around the throat, and with richly 
embroidered muslin ruffles at the bosom and wrists. $\mathrm{He}$ is seated in a carved mahogany chair, holding in his left hand a book, while his right arm rests upon a table covered with green cloth. Two of the fingers of the right hand are between the leaves of the book, as if to keep his place while he speaks. "President John Adams used to say that the portrait was so admirable and lifelike that it seemed as if his old friend must rise to bid him welcome." Josiah Quincy was born in Braintree, Mass., in I709; graduated at Harvard College in 1728 . He was a distinguished merchant and a much valued correspondent of Slingsby Bethel, Lord Mayor of London. He established the first glass and spermaceti works in America. He was an intimate friend of Franklin, Bowdoin and President John Adams, who used to describe him as remarkable for the elegance of his manner and the grace of his address. He was a strenuous patriot and lived to see the freedom of the Colonies, dying in $\mathbf{1 7 8 4}$. In 1770 he erected the mansion house, built upon the lands granted to the family in 1635, and which was the summer residence of President Quincy, his grandson. This portrait is in the Boston Museum of Fine Arts. 


\section{Samuel Quincy}

This picture is of life size and more than half length, and is in the original carved frame. $\mathrm{Mr}$. Quincy is dressed in wig, gown and bands, with ruffles on his wrists. He is seated by a table, pen in hand, and manuscripts lie by his side. He was born in $\mathbf{1} 735$ and graduated at Harvard College in I754; he was Solicitor-General for the Province, in that capacity prosecuting the soldiers for the Boston Massacre. His brother, Josiah Quincy, Jr., was counsel for the defense. On account of his royalist principles he left the country in 1775 , and never returned. He died in $\mathbf{1 7 8 9}$, and was buried at Bristol, England. The picture is now in the Boston Museum of Fine Arts, lent by Miss Grace Treadwell.

\section{Mrs. Samuel Quincy}

This is a companion picture to that of her husband. She is dressed in rose-colored brocade, with loose sleeves, trimmed with lace, and a lace cap, and wears a dark velvet hat with a white feather, and in one hand has a sprig of larkspur. Her maiden name was Hannah Hill; she died in I783. This picture is now in the Museum of Fine Arts, Boston, lent by Miss Grace Treadwell. 


\section{Suzanne Randolph}

This superb full length portrait of Miss Randolph was painted while she resided with her father, who was at the time representing the United States in England. It is well known as one of the very best examples of Copley's English period. It was shown in London, in 1890 , at that time belonging to Rev. W. C. Randolph. The picture measures fifty-three by seventy-eight inches. It hung for a long time in the Boston Museum of Fine Arts, and is now owned by Mrs. E. D. Brandagee of Jamaica Plain, Mass.

\section{Mrs. Daniel Rea and Daughter}

This is an early example of Copley's work and is very characteristic of the period. It is signed and dated 1757. Mrs. Rea was a Miss Salter of Salem. Daniel Rea of Beverly and Boston was her third husband. Their daughter Elizabeth, is the infant represented in the picture. Mrs. H. C. Thompson is the present owner of the picture.

\section{The Red Cross Knight}

The scene is taken from Spencer's “Faerie Queene." On the left of the picture is Lord Lyndhurst as a young man, seventeen years of age, as St. George, dressed in full armor, advancing into a garden; next 
him stands his sister, Mrs. Greene, and beyond her is Miss Mary Copley. The figures of the ladies are very charming. The picture, which is large, was painted about 1789, was exhibited at the Royal Academy in 1793, and is now in the possession of Mr. Gordon Dexter of Boston. A sketch for this painting is owned by Lord Aberdare, Eaton Square, London.

\section{The Resurrection}

This picture, painted in 1810 and exhibited in the Royal Academy in 1812, is the last picture painted by Copley.

\section{Paul Revere}

This picture is twenty-eight inches long by twentyfive in width and represents the patriot leaning on a table and without a coat. He wears a white shirt and waistcoat. His hair is without powder. The right hand supports the chin while the left holds a silver teapot. Engraving tools are scattered upon the table. Colonel Revere was a descendant of a Huguenot family, was born in 1735 , and died in 1818 . In 1756 he was a Lieutenant of Artillery, stationed at Fort Edward, near Lake George. On his return to Boston he established himself as an engraver and goldsmith. In $\mathbf{I} 775$ he engraved the plates for the 
paper money ordered by Congress, and was also a successful manufacturer of gun powder. In I779 he served in the Penobscot Expedition, and afterwards was a Colonel of Artillery, Grand Master of Freemasons, and First President of the Massachusetts Charitable Association. The picture, after having lain neglected in an attic for many years, was restored and now belongs to Mrs. John Revere of Canton, Mass.

\section{Charles Lloyd Richards}

He was a Captain in the 95th Regiment. Copley painted his portrait in New York in I77I.

\section{Mrs. Eliza Whiting Richards}

There is a portrait of this lady by Copley owned by her great granddaughter, Miss Martha D. Wilson, of Wakefield, Mass.

\section{John RichaRds}

Of New London, Conn., son of John and Ann Prentice Richards, and grandson of John Richards, who emigrated from Wales, and died in New London in $\mathbf{1 6 8 7 . ~ M r . ~ R i c h a r d s ~ w a s ~ b o r n ~ i n ~} 1736$ and graduated at Yale College in I757. Having inherited a handsome fortune, he followed no profession. He 
married for his first wife, July 5, I755, Susannah Grey, and for his second wife, June 6, I768, Catharine Saltonstall, a daughter of Governor Saltonstall. The size of the picture is two feet two inches high by two feet wide. The dress is an open coat, with wrought gold buttons, a brown waistcoat, and muslin cravat. The face is that of a fine-looking man, of florid complexion, black hair and large, dark eyes. This picture was in the possession of $\mathrm{Mr}$. George Richards Lewis of New London, Conn.

\section{R. RichaRds}

A portrait of Mr. Richards of Lincoln's Inn was exhibited at the Royal Academy in I80I.

\section{LORd Rodney}

A miniature of George Brydges Rodney, first Baron Rodney, born I7I8, and died I792, showing him in full uniform, is in England.

\section{Mr. Rogers of SAlem}

This fine picture represents Mr. Rogers sitting sideways upon a chair. His dress is a plum-colored coat and a gold laced waistcoat. His hair is without powder. This portrait was exhibited at the exhibition of the Society of British Artists in London in 
I768. It belongs to the Estate of Morrill Wyman of Cambridge, and is in the Boston Museum of Fine Arts.

\section{Mrs. Abigail Rogers}

The wife of Daniel Denison Rogers, of Boston, was the second child of Henry Bromfield, and Margaret, his wife, nee Fairweather. She was born in 1753 and died in I79I. While residing in Europe this portrait was painted by Copley, her half uncle. It is of life size, three-fourths length, and represents a lady out for a walk and just drawing on her glove. She is dressed in white satin, with a white muslin mantle over her shoulders. Her hair is powdered, and her hat, which has a wide fall of lace around the rim, and a large mass of dark red ribbon on the crown, is surmounted by white plumes. Near where she stands is the trunk of a tree, and in the distance is a mountainous country and a gorgeous sky. A copy of this, possibly by Copley, is owned by Mrs. W. C. Cabot of Boston. The original is in the possession of Miss A. P. Rogers of Boston.

\section{Mrs. Daniel Rogers}

She was Elizabeth, daughter of Colonel John Gorham; born December ro, r739; married Daniel Rogers, November 6, r759; died March 14, r769. 
The picture is of three-fourths length and represents the lady in a satin dress, with a hat hanging from her arm. She seems to be coming from a garden. The picture is now owned by Miss Louisa Low, Stamford, Conn.

\section{JOHN ROGERS}

The Protomartyr, of whom there is a portrait in the possession of the Massachusetts Historical Society, evidently taken from an engraving. It is of half length, and is signed and dated 1759 , and was presented to the Society by Mr. J. F. Eliot of Boston.

\section{Mrs. Lucy Boylston Rogers}

Mrs. Rogers was the daughter of Thomas Boylston; she was born September 28, 1728, and married Timothy Rogers of Gloucester, Mass. The picture measures forty by fifty inches and is in its original carved frame. The subject is represented at life size, in a sitting position, three-quarters length, with low corsage, a cream color silk dress, and with a wine color shawl. Her right arm is shown resting on the arm of a chair and left hand resting in her lap. The picture belongs to the Estate of Miss Louisa C. A. Nightingale. 


\section{ISAAC ROYALL}

That Copley painted portraits of Isaac Royall and his wife is evident from the bill produced in connection with the portrait of his daughter, Polly Royall.

Isaac Royall, married March 27, I738, Elizabeth McIntosh and in 1775 went to England with other Loyalists where he died in $\mathbf{I 7 8} \mathbf{I}$.

\section{Polly Royall}

The only evidence the author has that Copley painted a portrait of this lady is contained in a bill in the handwriting of Henry Pelham.

Boston The Honble. Isaac Royall Esqr. to J. S. Copley Dr. $£$ s d

To a Packg Box omitted in former Acct ○ 94 To a portrait in Crayons of Miss Polly Royall

To gold carved Frame for Do

To London Crown Glass for Do

To his Lady's portrait half length

To his own Do Do

5 I2 0

440

I9 120

19120

I9 120

To portraits of Mr. Mackintosh and Lady I4 $\quad$ I

\section{Judge Chambers Russell}

An oval picture representing the figure in the red robes and the wig of an English judge. He was born 
in 1713 , graduated from Harvard College in 1731 , and died in 1767 . He was Judge of the Superior Court, and also a Judge of Admiralty. The picture was in the possession of his descendant, Colonel Charles R. Codman.

Mrs. Katharine Russell

The wife of Judge James Russell of Charlestown, and daughter of Hon. Thomas Graves. She was born in 1717 and died in 1778 . The figure is seated in an arm chair and holds in one hand a book. The dress is light brown satin, with a white lawn cape, and long mittens on the hands and arms. The size of the picture is four feet long by four and a quarter wide. It belongs to the Estate of Henry R. Dalton.

\section{Stephen Salisbury}

A very fine miniature said to be a portrait of $\mathrm{Mr}$. Salisbury, undoubtedly by Copley, is in the Metropolitan Museum of Art, New York City.

\section{Judge Richard Salstonstall}

This picture is forty by fifty inches, and of threefourths length. The dress is a brown velvet coat, a long blue velvet waistcoat, extending to the bottom of the picture, with a rich gold lace border around the edges of the pockets. The sleeves are loose, with 
large ruffles around the hand. The right hand is resting on the hip, the left extending in an attitude of speaking, or addressing an assembly. It is a dignified and pleasing picture. Judge Saltonstall was born in Haverhill, June 24, I703; graduated at Harvard College in I 722; and died October 20, 1756. He was Judge of the Superior Court from I 736 until his death. At the age of twenty-three he received a commission as Colonel. He was noted for his elegant hospitality, his eloquence, and noble, generous character, and was a learned and accomplished jurist. The picture is owned by R. M. Saltonstall of Brookline.

\section{Samuel and Eli}

The well-known picture which was engraved by Valentine Green for Macklin's Bible, and which sold in London at auction in 1864 by the executors of Lord Lyndhurst for I05 pounds, was destroyed by fire while in the house of Mr. Henry Graves in London in $\mathbf{I} 867$.

A replica of this picture was destroyed by fire while in a shop being repaired for the purchaser who bought it at the Lyndhurst sale. Young Copley was the model for Samuel. A copy of the picture in increased proportions is in Milan Cathedral. The original picture belonged to Mr. Ashton of Mold, near Liverpool. 
Colonel Epes Sargent, Sr.

This picture is thirty-nine by forty-nine inches, and is of two-thirds length. It represents an old gentleman, about sixty or seventy years of age, his right elbow on the base of a column, the left hand thrust into his side pocket, while the right is spread on his chest, presenting the entire back of the hand to view. He is dressed in a large, single-breasted coat of drab broadcloth, buttoned up to the throat, with full long cuffs, narrow white muslin neckcloth, and broad white lawn ruffles surrounding the wrists, while a strip of gold lace from the inner vest lightens the lower part of the costume. Upon the head is a light, curling, powdered wig. There is a tree in the distance. The date of this picture is not known but is probably previous to 1760 . Mr. Sargent was born in Gloucester in 1690 and was the sixth child of William Sargent and Mary Duncan. He married first, Esther MacCarty, of Roxbury; and second, the widow Brown of Salem, a granddaughter of Governor Joseph Dudley, and daughter of John Winthrop. After his second marriage he removed to Salem, where he died in I762. He held a colonel's commission under King George II. By his first wife he had three sons, Epes, Daniel and Winthrop, and two daughters, Esther, who married Thomas 
Goldthwait and Sarah, who married Colonel Allen. He had two sons, John and Paul Dudley, by his second wife. This portrait is owned by Mrs. G. H. Clements.

\section{Mrs. Epes Sargent, SR.}

The picture is companion in size to that of her husband. It was probably painted about $\mathbf{1 7 6}$ I. She was a widow Browne at the time of her marriage to Colonel Sargent. She was a daughter of Governor Winthrop. She is in a blue dress, rose color shawl, a rose is in the low cut, lace-trimmed corsage, and she holds also a rose in her right hand, which is resting in her lap. The picture has a landscape background. The lady is standing with her left arm resting on a rock. The portrait belongs to Mr. George N. Black of Boston.

\section{Epes Sargent, Jr.}

This picture is of three-fourths length, measuring thirty-nine by forty-nine inches, and was probably painted in 1764 . He is represented standing, with a slender, erect figure, dressed in a single-breasted coat and waistcoat of drab broadcloth, quite long, without collar. The waistcoat is buttoned to the throat, the coat being open. The cuffs are very long and held back by three large buttons; a white 
muslin neckcloth is tied in a simple bow, and the end tucked into the waistcoat. The short sleeves terminate in broad lawn ruffles. His right elbow rests on the square base of a column, with the hand hanging easily in front. The left hand just touches the top of a balustrade. A full powdered wig covers the head. It is in the later style of the painter, and is a charming portrait. He was born in Gloucester in 1720 , the eldest child of Epes Sargent and Esther MacCarty. He married Catharine Osborne of Boston in 1745 , and was very distinguished as a merchant. He was a Loyalist during the Revolution, although his sons took the side of the Colonies. He died in $\mathrm{r} 779$. This portrait is owned by Mrs. G. H. Clements.

Mrs. Epes Sargent, Jr.

Who was Catharine Osborne. A companion picture to that of her husband. She is represented as standing, apparently waiting to mount her horse. By her left side, the water of a fountain is falling into and over part of a fluted basin of dark marble, supported by scrolls terminated by the head of some heraldic animal; in the distance is a tree, and the sky appears beyond, broken by a few clouds reflecting the sunlight. She is dressed in a blue-green riding habit of thick camlet or poplin, consisting of a long- 
waisted jacket with an underskirt of the same material falling in very full and bold folds below. The neck and sleeves are relieved by a broad collar and cuffs of white satin, and the whole trimmed with gold lace and gilt buttons; white muslin ruffles surround the throat and wrists, the former being confined by a black ribbon. Her dark brown hair is combed back from a high forehead, with a small pink bow at the top of the head. Her ungloved hands are crossed in an easy manner in front of her, the right one holding a riding whip, which rests on her shoulder, while a long white ribbon hangs from the handle. A black satin riding cap, trimmed with black lace and adorned with a fine long white ostrich feather, hangs lightly from her left hand in front. The picture is marked with Copley's autograph and the date of 1764 . Mrs. Sargent was born in 1722, the fifth child of Hon. John Osborn, one of the Governor's Council, and Sarah Woodbury. Her father was born in Bristol, R. I., removed to Boston, and subsequently married Madame Hutchinson, Madame Fitch and Miss Pierce. He died in $\mathbf{I} 768$. Mrs. Sargent was married in 1745 . This portrait is owned by Mrs. G. H. Clements. 


\section{Mary Turner Sargent}

Wife of Daniel Sargent and son of Epes Sargent, Sr. This picture is of three-fourths length. She is dressed in a rich satin, handsomely trimmed and decorated with lace. In her right hand she holds a dish to a fountain, while with her left she draws back her skirt. Her hair is without powder, and around her throat is a lace ruche. This beautiful picture is signed John Singleton Copley, and dated I769.

\section{Samuel Phillips Savage}

Son of Arthur and Faith (Phillips) Savage. Born in Boston, April 27, 1718; died in Weston, Mass., December 9, 1797. He married in 1742, Sarah Tyler, daughter of William and Sarah (Royall) Tyler, of Boston. She was born in Boston, March 2I, I718, and died there February I2, I764. Their portraits were painted by Copley in 1763. Samuel Savage was a prominent merchant of Boston; selectman 1760-6I; moderator of the meeting in Old South Church which determined the fate of the tea in Boston Harbor; appointed a judge of the Inferior Court for Middlesex County in 1775, and from 1782 until his death was judge of the Court of Common Pleas for Middlesex County. In 1774 he represented the town of Weston in the Provincial 
Congress of Deputies, and was President of the Board of War in Massachusetts from 1776 until his death. Following is a bill for his portrait.

Boston, December Ist, I764.

Received of Samuel Phillips Savage, Esq., Six pounds, thirteen shillings and four pence, which is the balance in full for two portraits, one of his Lady, the other of himself.

\section{John S. Copley.}

This portrait belongs to John Richard Savage of Garden City, Long Island.

\section{Mrs. Sarah Savage}

This lady was the wife of Samuel Phillips Savage. The portrait measures forty by fifty inches. She wears a cap tied under the chin with white ribbon; elbow sleeves, lace-trimmed, and her right arm rests on a table. There is a landscape background. The picture belongs to her great grandson, Samuel Savage Shaw of Boston.

\section{G. W. Schilling}

A portrait of this gentleman was painted in 1769 , according to a letter to Copley under that date.

\section{JOHN SCOLLLAY}

A portrait of life size, representing a portly man, with wig and plain brown dress, sitting with his hand 
resting on a ledger, near which is an inkstand and a pen. He was chairman of the Board of Selectmen of Boston from I774 to I790. John Scollay, writing to Copley in 1782 said, "I trust, amidst this blaze of prosperity, that you don't forget your dear native country, and the cause it is engaged in, which I know lay once near your heart, and I trust does so still." This picture belongs to Dr. W. Sturgis Bigelow, of 56 Beacon Street, Boston.

\section{Mrs. John Scollay}

This is a fine example of Copley's work at his best American period. It is signed and dated 1763 . The subject is represented at three-quarters length in a seated attitude. The portrait measures twentyseven by thirty-five inches. The dress is of dark brown with lace at the neck and sleeves which come to the elbows. She wears a wine color scarf. The hair combed back from the forehead is without ornament. Her right arm rests on a table with hand against the face. The picture has a background showing a draped crimson curtain. It is in its original carved frame and belongs to Mr. W. Prentiss Parker of Boston.

\section{Mrs. Dorothy Quincy Scott}

She was the daughter of Edmund Quincy. First married John Hancock at Fairfield, Conn., in I775, 
afterwards Mr. Scott, in 1789 , and died in 1829 , aged eighty-two. The portrait is of three-fourths length, and represents the lady sitting in a chair. Her hand is raised to her face. A rich dress of pink brocade, a velvet band around the neck, and a muslin apron, complete the costume. It now hangs in the Museum of the Fine Arts, Boston, and belongs to the Estate of Mrs. Stephen Bowen.

\section{Governor George Scott}

This portrait, supposed to have been painted about I755, is an excellent example of the period. Governor Scott was Lieutenant-Governor of the Dominican Islands from $\mathrm{I} 763$ to $\mathrm{I} 768$. He was an intimate friend of General Winslow, Commissary-General of the Continental Army and to whom he presented this portrait. General Scott married Miss Erving of Boston, daughter of Hon. John Erving. He is represented as an officer in red and buff, standing three-quarters length with musket, powderhorn and belt at the side and hat under the right arm. The picture measures forty by fifty inches and is in its original carved frame. It is owned by "The Brook," of New York City. 
Mrs. George Scott

She was the wife of Governor George Scott of Dominica, and the daughter of Hon. John Erving, of Boston. She died in I768 at Dominica. The picture is in the possession of J. Langdon Erving of New York.

\section{JAMES ScotT}

In a letter to Copley dated London, September 5, 1766, signed James Scott, he says "I have got the portrait safe home, it gives great satisfaction.".

\section{Colonel Olney Scott}

This picture is of three-fourths length. The figure is seated, with the right elbow resting upon a table, and the hand supported by a book. The left leg is crossed over the right knee. The coat is brown, with a richly embroidered waistcoat, and in the shirt is a breast pin. The countenance is exceedingly intelligent and commanding. This picture belongs to George S. Winslow of Boston.

\section{Mrs. Olney Scott}

This is a companion picture to that of Colonel Scott, and represents a lady near a table, holding in her left hand a bunch of sweet peas. Her dress is of dark pink, and her right hand is raised, grasping 
the folds of a mantle. This picture is in the possession of George S. Winslow of Boston.

\section{David Sears}

There is a beautiful oval miniature of this gentleman, who was an eminent merchant of Boston, and the father of the Honorable David Sears. The dress is in the fashion of the times, the coat being of plum color. Mr. Sears was a fellow passenger of Mrs. Copley and her children in the ship Minerva, Captain Callahan, which sailed May 27th, I775, from Marblehead for London, and a tradition in the family is probably correct that the portrait was taken in that city. It is in the possession of the family.

$$
\text { Dr. Joseph Sewall }
$$

Copley published a mezzo engraving in 1766 for which purpose he painted Dr. Sewall's portrait. He was minister of the Old South Church from 17I3 until his death in $\mathbf{I} 769$.

\section{Sir Roger Sheafe}

Was born in Boston in $\mathbf{1 7 6 0 . ~ A t ~ t h e ~ e v a c u a t i o n ~}$ of Boston in 1776 he accompanied Earl Percy, afterward the Duke of Northumberland, by whom he was adopted, to England. There he was educated as a soldier, and rose rapidly in rank. In 1812 he was 
Major-General in the British Army, and was stationed in Canada. Finding a collesion with his own countrymen inevitable, he earnestly solicited employment elsewhere. His request was not granted, and commanding his troops at the battle of Queenstown Heights, he took General Winfield Scott and his brigade prisoners of war, for which service he was created a baronet of the United Kingdom. He married a niece of Sir Isaac Coffin, and died in 1850 . His portrait represents him as sitting in a chair, dressed in a brown coat and a laced cravat, and with his hair powdered. The picture is a half length, and is a beautiful specimen of Copley's latest manner. It was in the possession of Mrs. Henry Loring, of Brookline, a niece of the Baronet.

\section{EARl of Sidmouth}

There is in England a three-quarter length portrait of Henry Addington, first Earl of Sidmouth. He is represented in a standing position, sleeves heavily ornamented with gold lace, and holds a scroll with both hands. He wears a white wig. It was exhibited in the Royal Academy in 1809, and was engraved by Finden.

There is another portrait, of full length, of Addington in his robes of office as Speaker of the House of Commons and Member of the Privy Council. It 
was engraved by Dunkarton and published by Cople y in 1799. Addington was Speaker in 1794. In this portrait his right hand rests upon a manuscript partly unrolled. The background shows the House of Parliament. The portrait measures sixty-four by ninety-four inches and when it was publicly exhibited in 1868 belonged to Rt.-Hon. T. H. S. SothernEstcourt.

\section{Siege of Gibraltar}

This historical picture is one of Copley's masterpieces. It was made in 1789-I790 for the City of London. Several study heads, highly finished, are owned by Mrs. F. Gordon Dexter. The original picture is in the Council Chamber of Guildhall, London. It contains portraits of Major-General De La Motte, Colonel Duchenhausen, Colonel Schleppengull, Colonel Hugo and others. A sketch for this picture was sold at the Lyndhurst sale in I864. A small but highly finished picture was in the possession of Mr. Gregory, M. P.

\section{ANDrew Sigourney}

Was born in 1702, and was the son of Andrew Sigourney and Mary Germaine, his wife. He married in I73 I, Mary, only daughter of Dr. John Ronchon, and died in $\mathbf{1 7 7 2}$. His portrait, which is 
of three-quarters length, represents him as seated, and is that of a middle aged man, dressed in the costume of the times. His left hand rests on a long staff. This picture was in the possession of Mrs. Ross of Hartford, Conn.

\section{Mrs. Andrew Sigourney}

Died in $\mathbf{1 7 7 2 . ~ H e r ~ p o r t r a i t , ~ w h i c h ~ i s ~ o f ~ t h r e e - ~}$ quarters length, represents her as a fine looking woman of about forty years of age. She is seated. Her hair, which is dark and very thick, is drawn off from her forehead, and hangs in a heavy mass down her back. She wears no ornaments. Her right hand rests in her lap, while with her left she seems to be fastening her bodice. This picture was owned by Mrs. Ross, of Hartford, Conn.

\section{The Sitwell Family}

This is a group of several children of Francis Hurt Sitwell who died in I793; it was painted in 1785 and measures sixty-one and three-quarters by seventyone and one-half inches. It was shown at the Royal Academy in 1907 and is now owned by Sir George R. Sitwell. It was engraved by William Ward.

\section{Mrs. Skinner}

This is a highly finished portrait, representing a lady seated, her head resting on her hand. The 
hair is without powder, and is drawn back over a cushion. The picture is signed, "John Singleton Copley, pinxit, I772, Boston." It is in the Museum of Fine Arts, Boston.

\section{Captain John Small}

A crayon portrait and also a miniature were made of this officer by Copley. Captain Small was born in 1726 and died in 1796. He was long in America, as Captain of the 2 Ist Regiment in 1765 , MajorCommandant in the 84 th in $\mathbf{1 7 7 5}$, and LieutenantCommandant in the same regiment in 1780 . His portrait is also in Trumbull's picture of Bunker's Hill. The crayon was made for Mr. Philip Dumaresq and a copy made for Captain Small with some alterations, according to the Copley correspondence. The copy was sent to London to Alexander Small, a brother of Captain Small. The following letter to his brother refers to the picture.

"Mr. Copley drew a portrait in Crayons, about six years ago; which you are now posses'd of. He has hardly us'd his Pencil where the Performance has not been universally admired; so that his own works will speak far more in his favor than any thing that can be said by, Dear Sir, Your most dutiful and affectionate Brother,"

John Small

Salem neaar Danvers, June 9, I774. 


\section{Ann Tyng Smelt}

An early example of the artist's work, showing a light haired lady, dressed in blue satin and shepherd's dress, with crook and lamb, of three-quarters length, measuring forty by fifty inches. She was the daughter of Commodore Tyng and the wife of Captain Smelt, an officer in the British Army. She died the year the picture was painted. It is in its original carved frame and is signed and dated 1756. It belongs to Miss Mabel Harlow of Boston.

\section{Mrs. SMIth}

There is a portrait of a Mrs. Smith, which has always been in the family, in the possession of Mrs. John Heard of Ipswich, Mass.

\section{Elizabeth Storer Smith}

This is a companion picture to that of Isaac Smith, her husband. She was born in 1727 , and died in 1786. She is represented as attired in a blue satin under-dress, and an open crimson sacque. Her sleeves reach to the elbow, with white ruffles, and she holds in her hand a bunch of grapes. This is a very fine portrait, and is owned by Mr. W. Smith Carter of New York. 


\section{IsAac Smith}

A merchant of Boston. It is an oil painting of full length, four feet long by three feet, three inches wide. He was born in 1719 , and died in $1787 . \mathrm{He}$ is represented as seated at a table with writing materials, and is dressed in a plum-colored coat, small clothes, and a full wig. It is in the original frame. The following bill for this portrait and that of Mrs. Smith is in the Massachusetts Historical Society. 1769 Mr. Isaac Smith To J. S. Copley To painting his and his Lady's portrait in half length at $\mathbf{I}_{4}$ Guineas To 2 Carved Gold frames for Do.

$£ 39-4-0$ I 8-0-0

$£_{57-4-0}$

Received the contents in full John Singleton Copley.

This portrait now belongs to Mr. W. Smith Carter, of New York.

\section{Rev. William Smith}

A portrait in pastel, measuring sixteen by twenty inches, shows the subject in clerical robe, white wig, etc. It is owned by Mr. R. C. Greenleaf and is in the Metropolitan Art Museum. 
Mrs. W. S. Smith

In regard to this painting $\mathrm{Mr}$. Charles Francis Adams says: "This picture was a portrait of Abigail, the only daughter of John Adams, who married Col. W. S. Smith, of Jamaica, New York, then Secretary of Legation to Mr. Adams in London, and died in 1813. It must have been taken somewhere about the year 1787. It belonged to her brother, John Quincy, and was by him given to Mrs. Smith's only daughter, Mrs. De Windt, of Fishkill, Duchess County, New York. It was a remarkably attractive picture but unfortunately it was destroyed in a conflagration, which took place a few years since, of the mansion of Mr. De Windt." Mr. Charles F. Adams has a miniature copy of this.

\section{John Sparhawk}

This is an example of Copley's English miniature work painted either in 1783 or 1784 . The subject was the son of John Sparhawk, Jr., and Jane Porter Sparhawk, who was grandniece of Chief-Justice Sewall. He was born in 1743 and died in 1784 . He was the nephew of Colonel Nathaniel Sparhawk.

Col. Nathaniel Sparhawk

Was the son of Rev. John Sparhawk, of Bristol, R. I., who died in I7I8. His mother was afterwards 
married to Jonathan Waldo, a prominent merchant of Boston, by whom Nathaniel Sparhawk was educated. On June IO, I742, he married Elizabeth, daughter of Sir William Pepperell. He served on the Committee of Correspondence as one of the representatives from Cambridge in $\mathbf{1 7 7 2 . ~ T h e ~ s i z e ~}$ of this picture is ninety inches long by fifty-eight in width, and represents a gentleman dressed in rose colored velvet. The right hand is in the pocket, the left holds a scroll. It is signed "J. S. Copley, i764." The figure leans in an easy attitude against a pillar. Behind is a stairway ornamented with a vase, and beyond this an arch with statues and a landscape. This portrait belongs to the estate of Mr. F. R. Rindge, Cambridge, Mass., and is now in the Boston Museum of Fine Arts.

Another portrait, twenty-eight by thirty-six inches, belonging to Mr. Everett P. Wheeler of New York, was shown in the Hudson-Fulton Exhibition in 1909.

\section{Mrs. Nathaniel Sparhawk}

Was Elizabeth, daughter of Sir William Pepperell. The size of this picture is twenty-six inches by twentyone inches. The dress is a pearl-colored silk, with a white scarf over one shoulder. There are pearl ornaments in her hair and about her neck. The 
portrait was in the possession of her great granddaughter, Mrs. Hampden Cutts of Brattleboro, Vermont.

\section{Earl Spencer}

The full length portrait of Rt. Hon. George John Spencer, Earl Spencer, Viscount Althorp, was born in 1758 and died in 1834 . First Lord Commissioner of the Admiralty, from 1795 to I80I, was engraved by Dunkarton and published by Copley in $\mathbf{I} 80 \mathrm{I}$. He is dressed in his full robes and is represented as Knight of the Garter. The picture shows an outdoor background with a castle in the distance. It was exhibited in the Royal Academy in 1800 . It measures sixty-seven by one hundred and four inches. The original picture is in the National Portrait Gallery in London.

\section{Mrs. George Spooner}

Her maiden name was Phoebe, the daughter of John and Anna Vassall Borland. A miniature representing a pretty young woman of sixteen years of age, which was taken the year before her marriage. There is no tradition as to the author of this miniature, but from the similarity of it to others of his works of this kind, there can be but little doubt that it was painted by Copley. The picture was in the possession of a niece, Miss Simpson of Boston. 


\section{William Spooner, M.D.}

He was born March 24, r760 and died February 15, 1836. The portrait was painted in England while Dr. Spooner was studying medicine at the University of Edinboro where he received his degree in 1785. Later he returned to Boston and practised his profession. This is a half length, life-size portrait, the subject being shown dressed in a black coat with lace at the neck and wrist. He wears a white wig and the face is about three-quarters turned. The thumb of his right hand is in a book bearing the title "Elemento Medecini." The picture is about twentyfive by thirty inches in size and belongs to William Spooner's great grandson, Dr. Leslie H. Spooner of Boston.

\section{Mrs. Charles Startin}

Was Sarah Clarke, daughter of Richard Clarke and a sister of the artist's wife. The portrait is in oil but not finished, and represents only the head and neck of the lady. She wears a large hat. This portrait, and that of Mrs. Skinner, were bought by Mr. George Henry Timmins, a great nephew of Lord Lyndhurst, at the sale of that nobleman's pictures. The portrait now belongs to Mrs. W. Austin Wadsworth of Boston. 


\section{St. Cecilia}

A portrait of Mrs. Copley as St. Cecilia was exhibited at the Royal Academy in 1804 .

\section{Sir John St. Clair}

A fine example of Copley's miniature portraiture signed and dated $175^{8}$ is that of the above subject. It measures one and three-quarters by one and threeeighths, now owned by the Historical Society of Pennsylvania. Sir John St. Clair died in 1767.

\section{Mrs. Robert Stevens}

Whose maiden name was Anstice Elizabeth Wignall, was born in Antigua in 1722, married in 1738 , and died in 1790 . The picture is of life size, and represents a lady handsomely attired in the costume of the times. It is in the Newport Historical Society.

\section{Mrs. William Stevens}

She was Elizabeth, daughter of Joseph Allen, and married William Stevens, of Gloucester, in 1733. The portrait is of three-fourths length, and is in Copley's early manner. The lady is dressed in rosecolored satin, and is standing. It is in the possession of Mrs. Edward Russell of Boston. 
The Rev. Mr. Stillman and His Wife

Who was Judith Bullfinch. These are two oval miniatures. In the picture of Mrs. Stillman, the hair is powdered and rolled over a cushion, and is ornamented with a pink rose. These portraits are in the possession of Miss Julia C. Hixon of Brooklyn, N. Y.

\section{St. Jerome, After Correggio}

I find copy of this celebrated picture at Parma was a commission from Lord Grosvenor, and was painted by Copley at Parma in $\mathbf{1 7 7 5}$. It sold at the Lyndhurst sale in $\mathbf{I} 864$ for fifty-one guineas.

\section{Ebenezer Storer}

A colored crayon of half length, twenty-three inches long by seventeen wide. He was a merchant of Boston, was born in 1699 and died in $176 \mathrm{r}$. The dress is a green damask robe and he wears a green velvet cap. This picture is now owned by Mr. W. Smith Carter, of New York.

There is another portrait at Harvard College.

\section{MARy Storer}

A very fine crayon portrait of this lady is in the Metropolitan Museum of New York. She has a light blue dress, cut low and decorated with lace, a 
rose in her corsage, and hair dressed high and ornamented with pearls and flowers. The picture is dated $\mathbf{1} 765$.

\section{Mrs. Mary Storer}

A half-length crayon. The dress is of silk, with a black lace shawl and a cap of black lace with a white border. The following inscription is on the back of the portrait:

"Died December 8, I77I, Mrs. Mary Storer, widow of the late Ebenezer Storer, aged seventy-two. This portrait was taken two years before her death." It is now owned by a descendant, Miss G. G. Eaton of Boston.

Mrs. Mary (Edwards) Storer

The wife of Ebenezer Storer; she was born in 1700 and died in 1771. The dress is of black silk, with a white muslin handkerchief crossed over the neck and covered with black lace; a close fitting cap completes the costume. This portrait is in the possession of Mr. W. Smith Carter of New York.

Surrender of Admiral De Windt

This large and important picture of the surrender of the Dutch Admiral De Windt to Lord Duncan in I 797 was bought by Lord Duncan at the Lyndhurst 
Sale in $\mathbf{1 8 6 4}$. It is now at Camperdown, the family seat in Scotland. The picture was engraved by Ward. It contains portraits of Lord Duncan, Admiral De Windt, Captain Sir W. Fairfax, and the officers of H.M.S. Venerable. The action is supposed to be closed and Lord Duncan is seen on the deck of the Venerable surrounded by his officers. An English sailor is in the foreground bearing the enemy's colors.

\section{TAPEstry Design}

There is in the possession of Mrs. Green, of Brattleboro, Vermont, a tapestry, the design of which was said to have been drawn on the canvas by Copley.

There are also two tapestries painted by Copley in the possession of Mrs. Wainwright of Marblehead.

\section{The Taking of Dunkirk}

A large picture, measuring fifty-nine by ninetyfour inches, painted in 1800 , of this historical subject was sold at Christies, London, in May, 1909, from the estate of the Earl of Derby.

$$
\text { Jeremiah Taylor }
$$

He was the son of Mr. Taylor, of Hatton Garden, for many years the most eminent oculist of his time, and the grandson of the celebrated Chevalier Taylor, whose superior skill in the profession was well known 
to all Europe. Jeremiah Taylor was a member of the Royal College of Surgeons of London, and M.D. of the Medical College at Basle, Switzerland. The portrait is fresh in color and freely and broadly painted. It belongs to Thomas B. Clarke of New York.

Sir John Temple

He was a descendant of Leofric, Earl of Mercia, husband of the famous Countess Godiva, the founder of the great monastery at Coventry, in the time of Edward the Confessor. Sir John Temple, eighth Baronet, married Elizabeth, daughter of Governor Bowdoin. He was Commissioner of the Royal Navy, and after the war, was Consul-General of Great Britain to the United States. He is represented in full dress and a white wig. The picture which is a crayon, is signed J. S. Copley, and dated I764. It was in the possession of a descendant, Winthrop Tappan of Boston.

There is also a small portrait in oil measuring about seventeen by twenty-one inches, showing the interior of a room with the full length figure in court dress.

\section{Lady Temple}

Her maiden name was Elizabeth Bowdoin,daughter of Governor James Bowdoin. She married John Temple in 1767 , many years before he inherited his 
title which came to him in a round-about way through his great-grandfather, Rev. Thomas Temple, LL.D. She is represented in a handsome dress of the period, her neck decorated with a string of pearls, and her hair drawn back over a cushion. This picture, a crayon, was owned by Winthrop Tappan of Boston.

\section{Oxenbridge Thacher}

The Rev. Mr. Thacher, after graduating from Harvard College in 1738 , studied for the ministry and became a clergyman, afterwards abandoning the profession and becoming a lawyer. $\mathrm{He}$ was a sound and earnest patriot. He died in 1765 . The whereabouts of this picture is unknown.

\section{Mrs. Oxenbridge Thacher}

The whereabouts of this picture is unknown.

\section{Samuel Todd}

This is a fine example of Copley's miniature work. He was the son of William and Mary Todd, born July 24, I752 and died March 3I, I8I5. He is shown as a young man in light brown coat and full face. The portrait belongs to Miss Alba Davis.

\section{Mrs. Samuel Torrey}

She was Miss Catherine Gore, the sister of Goverernor Gore. It is a crayon of half size, taken as a 
child under or about five years old. It is in the possession of Miss Fanny R. Morse of Boston.

\section{Robert Traille}

A pastel portrait of this gentleman represents him in gray coat and waistcoat, trimmed with red. $\mathrm{He}$ wears a wig tied with a black bow and has on a white neck cloth. The figure is three-quarters turned. It measures about sixteen by twenty inches. The daughter of Mr. Traille, Mrs. Spence, was grandmother of James Russell Lowell. Mr. Traille lived in Portsmouth, N. H., during the latter years of the eighteenth century. He was the last Royal Collector of Customs at that port and being a Loyalist, returned to England. The picture was probably painted in 1762 , according to a letter to Copley, dated at Halifax, April 24, 1763, signed by Peter Traille. It belongs to Dr. Arthur C. Heffinger of Portsmouth, N. H.

\section{Captain Peter Traille}

That Copley painted a portrait of this gentleman is evident from the following letter dated Halifax, March 7, 1765 .

"Dear Sir:

By a letter from my friend Captain Bruce I find 
myself under great obligations to you, particularly in sending a couple of pieces of your drawings in crayons." The vessel was lost in passage together with the portraits. Captain Traille continues, "I have taken every step to find out if any of them are recovered and your drawings have become the prey of the barbarous Inhabitants.

signed Peter Traille."

It is possible that the crayon of Robert Traille, now at Portsmouth, N. H., may be one of these portraits, subsequently recovered.

\section{Madam Treadwell}

This picture is of half length and of life size. The lady is dressed in dove-colored satin. The sleeves are of half length with broad lawn ruffles. The hair is creped. There is a strong evidence that this picture was painted by Copley in $\mathbf{1 7 5 7}$, in his early manner. It is in the possession of Mr. Ralph Cutter, Brooklyn, N. Y.

\section{Captain'William Turner}

He was a lineal descendant of the fifth generation from Humphrey Turner, who came from Essex in England, to Plymouth, Massachusetts, in 1628 . He was born in 1745, and married in I767, Ann, the daughter of Edward Dumaresq and Mary Bauti- 
neaux, his wife. In June, I787, he was appointed by John Hancock an aide-de-camp to the Governor, and this commission, with John Hancock's signature and that of John Avery, his secretary, is in the possession of Samuel Epes Turner. This picture is a crayon, twenty-three inches long by seventeen wide. It is of life size and nearly half length. The subject is dressed in a coat and waistcoat of white cassimere, and wears a ruffled shirt, fastened in front by a pin, and his right hand is thrust into his bosom. His hair is powdered and dressed in a queue. This picture was in the possession of a grandson, Samuel F. Turner, of Baltimore, Md.

\section{Mrs. William Turner}

She was a daughter of Edward and Mary Dumaresq, and a great granddaughter of Hellier Dumaresq, Seigneur des Augres, and Jurat of the Royal Council of the Isle of Jersey. She was baptized at King's Chapel in Boston, in 1746 , and was married at the same place in 1767 , and died in 1824 . This is a companion picture to that of her husband, and is signed and dated i767. Her dress is a low-necked corsage of white satin. Over her shoulders is an ermine tippet. The throat is tightly clasped by a broad necklace, containing three rows of pearls. Her hair is rolled back over cushions, and ornamented 
by a small blue silk cap, fastened by four pearl headed pins. This picture was owned by a grandson, Samuel F. Turner, of Baltimore, Maryland.

\section{Mrs. Andrew Tyler}

Born I73 I, married 1746. Her maiden name was Mary Richards, and she married the Rev. Andrew Tyler, whose mother was a sister of Sir William Pepperell. This picture is a crayon of kit-kat size, and represents her as dressed in a blue silk and pink mantle. Her hair is without powder, and a circlet of pearls close under her chin completes her costume. The portrait is in the possession of the New England Historic Genealogical Society, and was presented by her grandson, Captain George Jackson Tyler of Providence.

\section{John Tyng Tyler}

This portrait is a quaint yet charming example of Copley's pastel work, showing the subject, who died July 23,1767 , as a child of five and one-half years of age. The size of the picture is seventeen by twentytwo inches. It has a landscape background and shows the child holding a black hat with blue lining, the hat holding a bunch of cherries. He has a brown coat and narrow black tie. John Tyng Tyler was the son of Joseph Tyler and Frances Tyng Tyler. The portrait belongs to Mr. F. S. Whitwell of Boston. 


\section{Eleazer Tyng}

The picture is six feet long by four feet wide. Mr. Tyng was born in 1690 and died in 1775 . He owned a large tract of land on the Merrimac River, to which he subsequently gave the name of Tyngsborough. The portrait is dated in I772. It is a full length likeness of a venerable gentleman and represents him as sitting, as old men do, in an attitude of perfect rest. His countenance is benignant. The dress is a drab coat and small clothes with black stockings, and he wears a full wig. It is a very highly finished picture. Eleazer Tyng was the grandson of Edward Tyng, whose daughter, Rebecca, was married to Governor Joseph Dudley. The portrait is in the possession of Copley Amory and hangs in the Museum of Fine Arts, Boston.

\section{Elizabeth Ross Tyng}

Wife of William Tyng of Portland, whom she married November 3, I769. She was the only child of Captain Alexander Ross, shipmaster and merchant, of Portland, Maine. The portrait was made when the subject was sixteen years of age and measures forty by fifty inches. She is represented as dressed in a wine color silk, low neck, with an ermine scarf over the shoulders. She has auburn hair, dressed 
high with ribbon at the top and has a dove perched on her outstretched left hand. The picture belongs to Miss Mabel Harlow of Boston.

\section{Colonel William Tyng}

A miniature by Copley of Colonel Tyng is owned by Miss Harlow, a descendant of Rev. Timothy Hilliard. There is a sheaf of hair bound with a pearl clasp on the reverse side. Colonel Tyng was born in Boston, August 17, 1739, and kept a bookstore in Cornhill, Boston, and later moved to his estates inherited from his father, Commodore Edward Tyng, at Falmouth, Maine, becoming sheriff of Cumberland County. He married Elizabeth Ross. William Tyng was a colonel under Gage in 1774. At the bombardment of Falmouth by Captain Mowatt, R. N., in 1775 , this portrait and the other of the Tyng family, were removed from the house for safety.

\section{William Vans and His Wife}

There were said to have been portraits of the above in the possession of a Miss Vans of Boston. Their whereabouts is now unknown.

\section{Thomas William Vawdrey}

This is a very fine example of Copley's work at his best English period. The picture measures twenty- 
eight and one-half inches by thirty-five inches. $\mathrm{He}$ is shown at half length, figure turned to the right. The costume is pale blue with lace at the neck and sleeves. He wears a white wig and his hands are loosely clasped; the background is dark gray. The picture, which is in an excellent state of preservation, belongs to Henry Reinhardt of New, York City.

\section{Hon. Daniel Crommelin Verplanck}

This portrait, painted about the same time as that of his father, Samuel Verplanck, represents a child full length, about six years of age, playing with a squirrel. The picture was probably painted during Copley's residence in New York City in 1773, and is now owned by Mr. W. E. Verplanck of Fishkillon-Hudson.

\section{Mrs. Gulian Verplanck}

This is a very handsome portrait of the lady and her grandchild, Gulian McEvers. She was Mary Crommelin, born July I2, I712, and married Gulian Verplanck, September 8, I737. She was the mother of Mary Verplanck, who married Charles McEvers in I763, and of Anne Verplanck, who married Colonel Gabriel G. Ludlow in 1760, who was afterwards Governor of the Province of New Brunswick. The canvas measures forty by fifty inches and is life size 
to below the knees. She is seated in a red brocaded chair, face slightly turned to the left, and her right hand resting on the shoulder of the child, who is standing at her knee. The child wears a white dress and blue sash, and hat trimmed with a blue feather. The picture is now in the possession of Mrs. P. J. L. Searing of New York City.

\section{Samuel Verplanck}

This portrait painted about 1770 , represents a gentleman about forty years of age, and is now owned by his descendant, Mr. Samuel Verplanck of Fishkill-on-Hudson.

\section{Mrs. Judge Vinal}

Whose maiden name was Osborn. This picture represents a young lady standing in a garden, the background being a wall, with a hill and water in the distance. It is of three-fourths length. The dress is of mauve pink satin, cut square in the neck, and ornamented with rich lace. The hair and eyes are dark. The picture is owned by Frederic Amory of Boston.

\section{Mrs. Elijah Vose}

The subject of this portrait was Ruth Tufts, born I75I and died I821, and married Colonel Elijah 
Vose of Milton. She was the daughter of Captain Simon Tufts of Medford, Mass., and who was a merchant at Charleston, S. C. It is a picture of a handsome young woman with sloping shoulders and dressed in light blue. It is done in crayon and belongs to Mrs. William Brewster of Cambridge.

\section{DANIEL WAIT}

This picture is two feet and a half long and two feet wide. It is in the original frame, and represents a boy in a standing position. The dress is a cloth coat of the color of ashes of roses. The waistcoat is blue, and under his left arm he carries his hat. In the right hand, which is unfinished, he holds fruit, and his hair is without powder. The tradition is that Copley sailed for Europe before he could complete this picture, which therefore, must have been painted in I774. It has always been owned by the family, and is now in the possession of John S. Williams, of Boston.

\section{Mrs. Colonel Samuel Waldo}

Was Griselda, daughter of Lieutenant-Governor Andrew Oliver. She was born in 1737 , married in I760, and died in I76I. It is a life-sized head. The upper part of her dress, which is seen, is a blue flowered silk. Her hair and eyes are dark, and the 
left side of the hair is dressed with pearls and a small spray of flowers. She wears pearl earrings and around her throat is a lace tie.

There is a companion picture to this, representing a sister of Mrs. Waldo, in the possession of Mrs. Ellis, of Burlington, New Jersey.

\section{Mrs. William Walter}

Was Lydia, daughter of Hon. Benjamin Lynde, of Salem, who married Mary, daughter of Hon. John Bowles of Roxbury. She was born in $174 \mathrm{I}$ and married William Walter, D.D., rector of Trinity Church, Boston, in I766. The portrait, which represents her as dressed in a pale blue silk, trimmed with black lace, was painted about i 767 . She wears a rose in the corsage, and her hair is combed back and fastened with pearls and a pink ribbon. This picture is owned by Robert Walcott of Cambridge.

\section{Mrs. Jonathan Warner}

She was Mary, the daughter of Archibald Macpheadris, and the second wife of Hon. Jonathan Warner. She is represented as sitting, with a very beautiful garland of flowers in her lap. Her dress is a light brown satin. This portrait, measuring fifty inches long by thirty-nine wide, still hangs in her father's old house at Portsmouth, N. H., and is owned by Miss Evelyn Sherburne. 


\section{Mary Warner}

Was a daughter of the Hon. Jonathan Warner, who was born in 1726, and appointed member of the King's Council in 1766. He married for his first wife, Mary, daughter of Temple Nelson, Esq. They had one daughter, Mary, who married Colonel Samuel Sherburne, and was the subject of this picture. She is represented as a young lady about sixteen years of age, with a dress of yellowish brown satin, and standing with a bird resting on her left hand, while her right hand holds the ribbon which detains her pet. This picture is owned by Mrs. E. H. Harriman of New York.

\section{General James Warren}

A descendant of Richard, who settled at Plymouth in 1620 , was born in 1726 . Graduated at Harvard in $\mathbf{1 7 4 5}$, and died in $\mathbf{1} 808$. He married Mercy Otis. He was a man of large fortune and a distinguished patriot; a member of the General Court in 1776; was High Sheriff of the County, and President of the Provincial Congress after the death of General Joseph Warren. He was a Major-General of Militia. The picture is of three-fourths length, and of life size, and represents the General standing with his left hand grasping his cane, while the right is con- 
cealed by the lapel of his long waistcoat. His dress is a drab cloth coat and black waistcoat, ruffles and a grey wig. It now belongs to Winslow Warren of Dedham.

\section{Mrs. Mercy Otis Warren}

Wife of General James Warren, was a sister of the Patriot, James Otis. "She had," says Drake, "an active as well as a powerful mind. She wrote several satirical, poetical and dramatic pieces, among them a satire in the form of a drama, called 'The Group,' and another called 'The Adulator,' which were famous at the time. Her poems, full of patriotic feeling, were published in 1790 , while in 1805 she published her great work, "The History of the Revolutionary War." The figure is of life size, and of three-fourths length, and represents the lady as standing, training a nasturtium vine with her right hand, while the left is raised and stretched forward. The face is delicate and intellectual. The eyes and hair are dark, and her headdress is of white lace, trimmed with white satin ribbons. Her robe is dark green satin, with a pompadour waist, trimmed with point lace. There is a full plait at the back hanging from the shoulders, and her sleeves are also of point lace. White illusion trimmed with point lace, and fastened with a white satin bow, covers her neck. The front of the skirt 
and of the sleeves are elaborately trimmed with puffings of satin. This portrait is now owned by Winslow Warren of Dedham.

\section{General Joseph Warren}

Born June II, I74I ; killed at the battle of Bunker Hill, June 17, 1775. A full length figure. $\mathrm{He}$ is represented in costume. The canvas is about five feet long by four feet wide, and the coloring is very beautiful. It was one of Copley's last portraits before he left Boston for Europe in 1774, and as a piece of artistic skill, as well as for its historic interest, has been pronounced to be one of the most valuable of Copley's portraits in this country. "It was painted while General Warren was the presiding officer of the Massachusetts Congress." It was bequeathed to the Boston Museum of Fine Arts by Dr. Buckminster Brown.

Another portrait, twenty-nine inches long by twenty-four wide, represents him as seated at a table in citizen's dress, showing one hand only. This picture was originally owned by General Arnold Welles, who married General Warren's daughter. It passed from him to Dr. J. C. Warren, and from him to his grandson, the present Dr. John Collins Warren of Boston. 


\section{Mrs. Joseph WARren}

This portrait is a three-quarters length, seated figure of a handsome woman. It measures forty by fifty inches. She wears a light blue dress with pink overdress cut low in the neck. Her arm rests on the back of a chair. Mrs. Warren died in 1773, aged twenty-six years. This portrait is the pendant of that of General Warren and the two have always been together. It is now in the Museum of Fine Arts, Boston.

\section{WINSLOW WARREN}

Was a son of General James and Mercy Warren. The picture is of life size. The countenance is florid, with dark eyes and eyebrows. The coat is of light brown, with a dark velvet collar; a white neckcloth, ruffles, and powdered hair complete the costume. This picture was painted in London toward the close of the Revolution, and is now owned by Winslow Warren of Dedham.

\section{Watson AND THE Shark}

Representing the harbor of Havana, and Brooke Watson, afterwards Lord Mayor of London, attacked by a shark; the picture is taken at the moment of his rescue by a boat's crew. This picture was painted in 1778 and was engraved by Valentine 
Green in 1779. The original sketch for this picture is owned by Mrs. F. Gordon Dexter of Boston. There are three finished pictures, the original being in the possession of Lord Aberdare, Eaton Square, London, S. W. A duplicate hangs in the Foundling School, London, and a third picture is in the Boston Museum of Fine Arts, a gift from Mrs. George Von L. Meyer.

\section{Brooke Watson}

A portrait of Watson in his official robes as Lord Mayor of London is said to be by Copley and was owned by Mr. Pulitzer of New York.

\section{Elkanah Watson}

Son of Elkanah, and a half brother of Colonel George Watson, was a descendant of Robert, of Plymouth, 1623. He was born January 22, 1758 and died December 5, 1842. He was one of the most distinguished men of his time, and also one of the most active among those opposed to the English power. A friend of Franklin, Burke, Priestly and Watt. The picture represents him standing, and leaning against a pillar. In his right hand he holds a cane and a letter, and in his left a hat; a table stands near, over which is seen the sea with a ship bearing a flag. "The painting was finished," says Mr. Watson in his journal, "in most adnirable style, 
except the background, which Copley and I designed to represent a ship bearing to America the acknowledgment of our independence, with the sun rising upon the stars and stripes of the Union, streaming from her gaff. All was complete save the flag, which Copley did not deem it proper to hoist under present circumstances, as her gallery was a constant resort for the royal family and the nobility. I dined with the artist on the glorious fifth of December, $\mathbf{I} 782$. After listening with him to the speech of the king, formally recognizing the United States of America as in the rank of nations, previous to dinner, and immediately after our return from the House of Lords, he invited me into the studio, and there, with a bold hand, a master's touch, and I believe, an American heart, attached to the ship the Stars and Stripes; this was, I imagine, the first American flag hoisted in Old England." It is stated, in the life of Mr. Watson, that he paid one hundred guineas for this picture. It was in the possession of Mrs. Thompson of Philadelphia.

\section{Colonel George Watson}

Son of John Watson, married first Abigail Saltonstall; second, Elizabeth, daughter of Chief-Justice Peter Oliver. "He was an opulent and liberal merchant of Plymouth," says Thacher. The picture 
is of three-fourths length, and is in profile, representing Colonel Watson standing, with one hand resting on a table, the other holding a letter which he seems to read. $\mathrm{He}$ is dressed in a handsome brown suit, laced with gold. It is a very fine picture, dated and signed in monogram, 1765 . Colonel Watson was born in 1718 , and died in 1800 .

\section{Mrs. George Watson}

Daughter of Chief-Justice Oliver, was born in I735 and died in 1767, aged thirty-two. She is represented as dressed in rose-colored satin. The figure is somewhat in profile. The hair is without powder; the right hand holds a scarf, which is partially draped around the waist; in her left hand she bears a beautiful little vase. The whole picture is very well painted and graceful. It is dated and signed in monogram, 1765 , and belongs to Mrs. Inches. It was exhibited in the Boston Museum of Fine Arts in I9I I.

\section{Mary Watts}

A daughter of Sarah Osborne, whose second husband was Judge Samuel Watts. She married Dr. Edward Watts, a son of her stepfather. The picture is half length, twenty-nine inches long by twenty-four wide. The dress is of green satin, a bow 
at the waist and a pink scarf. The hair is without powder, surmounted by small white flowers. The ornaments are pearl earrings and a pearl necklace. It belongs to Mr. F. S. Moseley of Boston.

\section{Mrs. Samuel Watts}

Her maiden name was Sarah Osborne, a sister of Mrs. Epes Sargent, Jr. She married, first, Thomas Oxnard, who died in 1754; and second, in 1756 , Judge Samuel Watts. Her portrait, beautifully painted, represents her as a very fine-looking woman, dressed in black, with a widow's cap. The size of the picture is twenty-nine inches long by twenty-four inches wide. It is owned by Mrs. T. J. Lee of Boston.

\section{JoSEPH WEBB}

The following correspondence in part from Mr. Webb to Henry Pelham is the only evidence in the possession of the author that Copley painted his portrait. Joseph Webb was brother of Samuel Blachley Webb.

Sir,

"Your's of the 26th Ulo. I Recd. per the last post, and am much surprised at the Contents. I wish you wou'd take the trouble to call on Mr. Hyde, the Hartford Post Rider, to whom I paid the Money on the Receiving the Picture, which was last Fall. I 
was in Boston last February and shou'd hardly have come out of Town had it not have been paid; and was sorry that I was in such hurry as not to be able to wait on Mr. Copley out of Complisance, for I found Him vastly polite and genteel when $\mathrm{He}$ did the Work for me."

Jos. Webb

Wethersfield, June 3d, 1774 .

\section{Joshua Winslow}

Paymaster and Commissary-General of the forces sent to Acadia, under General John Winslow, was a son of Sheriff Edward Winslow, and descended from John, brother of Edward Winslow, the Governor of Massachusetts. This portrait represents him as wearing the undress uniform of a British officer, and is signed and dated $\mathbf{1} 755$.

\section{R. WILsON}

A portrait of this gentleman was exhibited by Copley at the Royal Academy in $\mathbf{I} 800$.

Prof. John Winthrop, LL.D., F.R.S.

He was the son of Judge Adam Winthrop; was born in Boston in 1714; graduated at Harvard in 1732; and died at Cambridge in 1779. He was Hollis Professor of Mathematics and Natural Phil- 
osophy in Harvard College for more than forty years. $\mathrm{He}$ was distinguished as a mathematician and an astronomer, and was a prolific writer on both subjects. He was also for some time Judge of Probate, Librarian of the College, and one of the founders of the American Academy. His first wife was Rebecca, daughter of James Townsend, and his second wife was Hannah Fayerweather, widow of Parr Tolman. The picture is four feet one inch long by three feet three inches wide. It formerly hung in Harvard Hall, but is now believed to be in Newport. The subject is seated at a table, holding an astronomical diagram. On the table is a study telescope and a heavy volume without a title. $\mathrm{He}$ is dressed in a black robe, with linen bands. The thoughtful expression of countenance is exceedingly well rendered.

\section{Mrs. JohN WINTHROP}

Was Hannah Fayerweather, daughter of Mr. Samuel Fayerweather of Cambridge, and was the widow of Parr Tolman. The picture is thirty-six inches by twenty-nine; the figure is half length, sitting in a high backed chair, covered with red; there is a mahogany table behind her. The portrait is painted in full face, and the hair is combed back under a white lace cap, trimmed with pink and white 
ribbon. Her dress is of blue silk and is ornamented with a bow of blue and white ribbon at the breast, the neckerchief and sleeves are of lace, and she wears a pearl necklace. In her hand she holds a branch on which are nectarines and the leaves, both reflected on the top of the table. On her left hand she wears a ring of diamonds and garnets. Mrs. Winthrop was the second wife of Prof. John Winthrop, Hollis Professor of Harvard College. This portrait was painted in 1774 and is a very fine example of Copley's work. It is owned by Edward D. Harris of Yonkers, N. Y., and is in the house, No. 8 Holyoke Place, Cambridge.

\section{SAMUEl WinthroP}

Was the son of Judge Adam Winthrop who died in 1743. The picture measures forty by fifty inches. It represents $\mathrm{Mr}$. Winthrop as seated by the side of a table, which is covered with a red cloth; upon the table is an inkstand and behind it is a red curtain. In his right hand he holds a pen and in the left there is a scroll. He is dressed in a black robe with linen bands. He was a very able lawyer, sometime Clerk of Suffolk County Court, and a brother of Prof. John Winthrop. This picture is at Harvard College. 


\section{The Rev. William Welsteed}

It is probable that the portrait of this gentleman, who was pastor of the new Brick Church in Long Lane, now Federal Street, in $\mathbf{1 7 2 8}$, now in the possession of the Massachusetts Historical Society, is the original picture painted by Copley in $175^{2}$ or $\mathbf{1 7 5 3}$, when he was but sixteen years of age, and the earliest known portrait by Copley. Mr. Welsteed was born in Boston and graduated at Harvard in 1716 , and was a tutor there from $\mathbf{I} 720$ to $\mathbf{I 7 2 8 . H e}$ was pastor for twenty-five years.

A duplicate is owned by a church in Waltham, Mass.

The picture was engraved and published by Copley in 1753 and is the only plate engraved by Copley of which there is any record.

\section{Sir John Wentworth, LL.D.}

Was born at Portsmouth, N. H., son of Mark Wentworth, in 1737; graduated at Harvard College in 1755 ; received the degree of LL.D. from Oxford in 1766 ; married his cousin, Mrs. Atkinson, in 1769 ; was created a Baronet in 1795 . He was the last Royal Governor of New Hampshire, I766 to 1775, and died at Halifax in $\mathbf{1} 820$. The picture is a fine crayon in its original black and gold frame, measures 
twenty-two by eighteen inches, and is signed and dated I769. He wears a light gray coat and waistcoat and a white wig. This picture is now in the possession of Mrs. Gordon Abbott.

Another pastel is owned by Miss Susan Wentworth at Portsmouth, N. H.

A very fine half length portrait of Sir John Wentworth is in the State Capitol at Concord, N. H. Governor Wentworth was a summer resident in the lake region of New Hampshire, having a mansion at Wolfboro.

\section{The Western Family}

"This picture, painted in 1802 , is one of the pictures," says Mrs. Amory, "that may be taken as a fine specimen of Copley's work in domestic portraiture." It is now in England.

Lord Western and Brother

This double portrait is of Lord Western and his brother, Rev. S. Western, as boys. It belonged in $\mathbf{1} 868$ to Sir Thos. Western.

\section{Frances Deering Wentworth}

Was a daughter of Samuel Wentworth of Boston. She was born in 1746 and died in England, February I4, I813; she married May I3, I762 her cousin, 
Theodore Atkinson, and afterwards married on November II, I769, another cousin, Sir John Wentworth. This portrait remained in the possession of Theodore Atkinson, Sr., from whom it was inherited by Frances Atkinson, who in I819 married Asa Freeman, of Dover, N. H. In 1873 it was purchased by John Fisher Sheafe for the private gallery of James Lenox, and was later added to the collection given by him to the City in 1870 . The picture, taken at the age of nineteen, is of threefourths length, and measures forty by fifty inches; her dress is of white satin, with pearls around the neck and in her hair. In her left hand she holds a chain, to which is attached a flying squirrel, which plays upon a table. The towns of Deering and Francestown, N. H., were named in her honor and that of her mother. The picture is signed John S. Copley, 1765 , and is in the New York Public Library.

\section{Mr. and Mrs. Joshua Wentworth}

That Copley had sittings for the portraits of Mr. and Mrs. Wentworth is evident from the following letter from Mr. Wentworth to Henry Pelham. We are not aware of the whereabouts of the portrait of Mrs. Wentworth. Mr. Wentworth evidently had only one sitting. Joshua Wentworth was born $\mathbf{I} 742$ and died 1809 , and was the son of Daniel and Eliza- 
beth Wentworth. Mrs. Wentworth was Sally Pierce.

Sir,

Portsmo., April 7th, I775.

Your favor of 14th March I rec'd 5th Inst. per post. Observe Mr. Copley's Bill for Mrs. Wentworth's portrait which, if compleat, shou'd with great pleasure discharge the demand, and as ready pay a like for mine. Mr. Copley, on my determination, of hav'g those portrait taken, Engag'd with me no other's shou'd impeed the execution of them. After Mrs. Wentworth had set many days, and myself one, he agreed and finish'd a Portrait for a Mrs. Babcock, wch exceedingly disapointed my Intentions, and my business cal'g me hither, was oblig'd to leave Boston, without a finish of either Portrait.

II cannot determine when Mrs Wentworth will (be) in Boston; her present Curcumstances will not admit her Visit'g it for some months.

I purpose to ride thither in May, if the hurry of Govement at home does not oblige the Inhabitants to abandon their Houses for a more agreeable retreat, from the Clamours of War.

I shall wait on you when I go to Boston, in the Interim am, Sir, Your mt. obt. Servt.

Josh. Wentworth. 


\section{Mrs. Oliver Whipple}

Was Abigail, youngest daughter of Dr. Sylvester Gardiner, born in $\mathbf{1 7 5 0}$, and a sister of the Hon. Mrs. Arthur Browne, of Mrs. Robert Hallowell and Mrs. Philip Dumaresq. The size of the picture is threefourths length, and the lady is represented as seated in the open air, dressed in a white satin robe with a blue silk mantle. She has a blue silk collar around her neck; her hair is without powder, and ornamented with small flowers; in the background on her right there is a large tree. This picture belongs to Mrs. James M. Codman of Brookline.

\section{Mrs. William Whipple}

Was the wife of William Whipple of Portsmouth, N. H., one of the signers of the Declaration of Independence. She was Catherine, the daughter of John Moffat, a descendant of John Mason, the Grantee of New Hampshire. The figure is of twothirds length, and nearly life size. She is painted as sitting under a tree, with a basket of roses in her left hand, and single red rose in her right. Her costume is a heavy yellowish brocade. The tradition is that the portrait was painted when she was very young. It now belongs to Miss Peabody of Cambridge. 


\section{DR. Whitworth}

A portrait of this gentleman, in crayon, is in the possession of a grandson, Mr. J. D. W. White, of Germantown, Penna.

\section{Hon. Richard Wibird}

Of the King's Colonial Council for New Hampshire, one of the seven proprietors of that colony; born I702, died 1765. He was a Judge of Probate, etc. The picture measures three feet one inch in length by two feet six inches in width, and represents a handsome man dressed in a brown velvet coat and waistcoat; there are fine lace ruffles over the hands, which are very delicate. He wears a light-colored wig, which completes his costume. This picture is owned by Mr. Penhallow of Boston.

\section{Anna Green Winslow}

The daughter of General Joshua Winslow. A very handsome miniature of this young lady was owned by the late Miss E. C. Trott of Niagara Falls.

\section{Lord Campbell}

There were portraits of Lord Campbell and his wife painted in Boston. He was the last Royal Governor of South Carolina. They are now in South Carolina. William Campbell was Governor of South 
Carolina $\mathbf{1 7 7 4 - 7 5}$ and previously Governor of Nova Scotia. He married Sarah, a sister of Ralph Izard. Died Sept. 5, 1778.

\section{Miss Copley}

A portrait of the daughter of Lord Lyndhurst and granddaughter of the artist, is owned by Lady Du Cane.

Dr. Moses Everett

This portrait is an early example of Copley's work in crayon. It shows the subject in brown coat, nearly full face, blue eyes, and natural powdered hair. The left hand is partly concealed in the waistcoat. Mr. Everett was pastor of a church at Dedham, Mass. The portrait belongs to Miss Alba Davis of Boston.

\section{Anne Francis}

A portrait of this lady was painted by Copley. She is represented in a standing position, half-length. Her dress is low at the neck, skirts full and plaited at the hips. She holds a flower in her left hand. There is a landscape background. It belongs to Col. F. C. Goldsborough of Maryland.

\section{Admiral Gambier}

This is a portrait of Copley's English period which shows the effect of the influence of his contemporaries 
upon his manner and technique. The picture is of three-quarters length, the figure in a standing position slightly turned towards the left. $\mathrm{He}$ is dressed in full uniform, the right hand grasping a staff and the left arm resting on the right hand and holding his hat in his left hand. There is a landscape background. James Gambier was born in 1723 and died in 1789. He was present at the capture of Louisburg in 1758, Commander-in-Chief of the North American station in $\mathbf{1 7 7 0}$, second in command under Howe at New York, Vice-Admiral in 1780 , and Commander at Jamaica in 1783 . The picture is owned by Messrs. R. C. and N. M. Vose of Boston.

\section{Miss Hill}

A portrait of this lady who was of the family of the Duke of Wellington is a very fine example of Copley's best English period. It belongs to George $\mathrm{R}$. White and is at his country residence at Manchester, Mass.

\section{Baron Amherst}

A portrait of Jeffrey Amherst (born I7I7 and died I797) was sold at auction in 1878 at the Suffolk Street Galleries, London. He commanded the expedition to North America in $175^{8}$ which took Louisburg, Fort 
$\mathrm{Du}$ Quesne, Ticonderoga, and Crown Point; and shared in the capture of Montreal. Governor of Virginia, in I763. Created Baron Amherst, in I776. Field Marshal, in 1796.

The whereabouts of the portrait is not known.

\section{Unknown Portraits}

There is owned by Mr. F. B. Smith of Worcester, Mass., a very distinguished and handsome portrait of a lady by Copley. She is represented as standing, with a table at her left, on which is a vase of tulips, one of which she is taking with her right hand. She is dressed in brown with lace ruffles on her sleeves.

A Girl and Dog. This picture is owned by J. A. Hewlett of New York.

An oval portrait of a lady, subject unknown, with a rose in her hair, is owned by Mrs. F. Gordon Dexter.

A boy wearing a hat decorated with feather, and holding a dog. This picture was in the possession of a branch of the White family of Boston.

Two miniatures said to be by Copley, were in the possession of Miss Sarah Hooper of Boston. 
A portrait of a lady, dressed in white satin, of three-fourths length, owned by Mrs. A. S. Porter, has always been in the family, and is believed to be by Copley.

A portrait in oil of an unknown man in Copley's early manner is lent by Edward L. Rand to the Boston Museum of Fine Arts and belongs to the Estate of the late Judge Lathrop. It has a landscape background and shows the subject with right hand resting on his hip and left hand on a globe.

A crayon bust portrait of a man, evidently an actor, is a fine example of Copley's work of this character. It is owned by Miss H. Elizabeth Snow and lent to the Boston Museum of Fine Arts.

Mr. Roland Ellis of Boston, has a picture forty inches long by thirty-six inches wide, representing two children, one standing holding fruit, the other seated. There is a small spaniel on the floor between them. The tradition is that it was painted by Copley, and it has many of the characteristics of some of his earliest works, especially in the coloring, the dog, the fruit and the jewels on the boy's dress. The picture came from the Clarke mansion, afterwards the residence of Sir Henry Frankland, and by his executors sold to the father of Mr. Ellis. There is 
some evidence to show that these children might have been grandchildren of Mr. Clarke, and were named Greenough. It is quite possible that Copley painted the picture.

A portrait of a lady by Copley is said to be in the possession of the Blair family in Washington, D. C.

According to "Tuckerman," Thomas W. Ludlow of New York owned portraits of his grandparents, and there was also a portrait by Copley in the possession of Mr. Dudley Hall of Medford, Mass.

According to Tuckerman's Book of the Artists published in $\mathbf{I} 870$ there was at that time a portrait by Copley belonging to William Thomas, Esq. of Baltimore, and a gentleman's portrait in the possession of Mrs. A. Woodruff of Perth Amboy, N. J. Portraits of Governor and Mrs. Shirley belonged to Mrs. E. S. Erving of New York.

A fine miniature portrait by Copley of a man is in the Boston Museum of Fine Arts, the gift of Mrs. R. M. Staigg.

A portrait of a man was exhibited at the Royal Academy belonging to Sir E. J. Poynter, P.R.A.

"A Family Group" measuring twenty-four by 
thirty-six was exhibited at Birmingham, England, belonging to G. T. Taylor.

There was shown a group of portraits in monochrome measuring twenty-four by thirty-six and one-half inches at the Grosvenor Gallery in I888, belonging to Mr. John Cleland.

A sketch of a young woman, full length, stooping with outstretched hands, evidently for one of Copley's historical compositions, is owned by Mrs. W. Austin Wadsworth of Boston.

\section{Warren Hastings}

The portrait of Hastings, Governor-General of India and also of Bengal, was sold at Christies, London, May I4, I858, from the collection of Sir Joseph Hawley. It is a small whole length portrait. Hastings was born 1732 and died 1818 . 


\section{NOTES}

The Department of Prints and Drawings at the British Museum has an early sketch book containing several studies signed and dated 1756 done with great care and from an anatomical standpoint.

It is possible that Dunlap mistook a portrait that Copley made of himself for purposes of having it engraved, for one of his son. This portrait was destroyed in the Boston fire of 1872 with many sketches and letters of the artist.

The historical picture of the Surrender of the Dutch Admiral De Winter was first exhibited at the "Pavilion" in London at the time subscriptions were received for the engraving by Anker Smith. The portrait group includes Admiral Duncan, Admiral De Winter, Captain Sir William Fairfax, Captain Cleland, Mr. Porteons the pilot, Mr. Burnet secretary to Lord Duncan, Lieutenant Little, Captain Trollope, Captain Oswald, and others.

The author has omitted several pictures mentioned by Mr. Perkins and a number described in a former edition by himself. Careful investigation has demonstrated that the pictures are of doubtful authenticity, or by some other artist than Copley. 



\section{Picture Index}

\begin{tabular}{|c|c|}
\hline PAGE & \\
\hline bercromby, Sir Robert...... 37 & Barrell, Mrs. Joseph .... \\
\hline bbot, Charles ......... & Barrell, Mrs. Anna Pierce .. \\
\hline aham Offering Isaac. & Barrell, Mrs. Hannah Fitch... \\
\hline ams, Abigail . . ......... 230 & Barrett, Anna............ \\
\hline dams, John .... & Barrett, John \\
\hline dams, Mrs. John .... & arrett, Mrs. John.... \\
\hline ams, John Quincy... & arrett, Judge Samuel \\
\hline ams, Samuel $\ldots .$. & Barrett, Mrs. Samuel . . \\
\hline dington, Henry . & Barrington, Admiral ... \\
\hline slie, Thomas . & row, Mr. $\quad . \ldots \ldots$ \\
\hline l, Elizabeth . & the of the Pyrenees \\
\hline .. 41 & . \\
\hline 41 & \\
\hline 42 & \\
\hline athaniel .. & \\
\hline & $\min$. \\
\hline 268 & rge . \\
\hline Sr. & \\
\hline 43 & \\
\hline Greene & ward \\
\hline $.44,44$ & gh, Lord \\
\hline & Mrs.... \\
\hline 45 & \\
\hline athaniel .... & Josep \\
\hline & Mrs \\
\hline & oebe $\ldots .$. \\
\hline & s. Sylvanus \\
\hline tor, The .. 179 & \\
\hline & , Nat \\
\hline 47 & beth \\
\hline 47 & $\mathrm{~J}$ \\
\hline 47 & \\
\hline & \\
\hline & \\
\hline & e Metcalf \\
\hline 50 & Mrs. Metcalf . \\
\hline . John & th the Squirrel. . \\
\hline 50 & \\
\hline Wilkes $\ldots . .$. . & Nicholas \\
\hline 1, Rev. Edward & Rebecca \\
\hline Mary ... & \\
\hline 27 & Mrs. Thomas \\
\hline & \\
\hline & \\
\hline
\end{tabular}




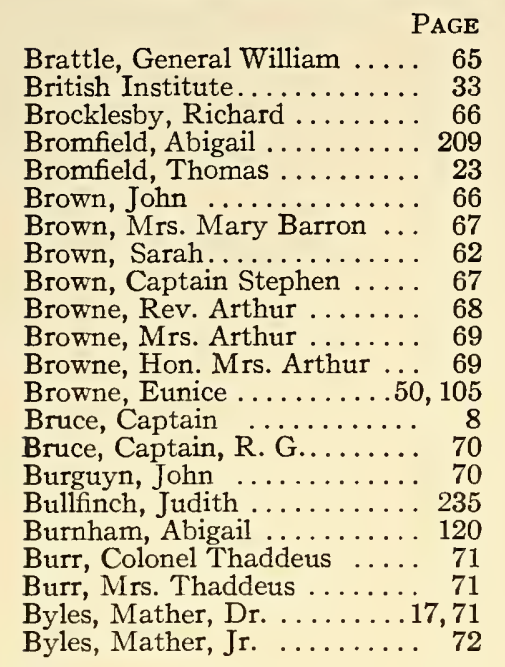

Cabot, George .......... 72

Cadwallader, Frances . . . . . . 100

Calif, Mrs. Joseph ........ 73

Campbell, Lord ........... 266

Camperdown, Lord . . . . . . 73

Carleton, Guy $\ldots \ldots \ldots \ldots .179$

Carr, Mrs............. 74

Carson, Mrs. William ...... 74

Cary, Samuel ........... 74

Cary, Mrs. Samuel ......... 74

Cary, Rev. Thomas........ 75

Catten, Miss............. 75

Cawthorne, Mr. . . . . . . 33, 75

Chardon, Peter ......... 75

Charles I., King of England

$16,35,76$

Charnock, Mary ......... 134

Chatham, Death of $\ldots 16,17,34,76$

Children of George III. . . . .31, 35

Clark, Mrs. Miriam Kilby .... 77

Clarke, Elizabeth. . . . . . 128, 175

Clarke, Dr. John . . . . . . . . 77

Clarke, Mrs. John ........ 78

Clarke, Mary .............. 56

Clarke, Richard . ......10,11, 78

Clarke, Sarah ............. 233

Clarke, Susannah......... 10

Clarke, William .......... 78

Cleland, William .......... 79
PAGE

Codman, John ........... 79

Codman, Rev. John .........33, 80

Codman, Richard ......... 80

Coffin, Mrs. ............ 81

Coffin, Thomas Aston ...... 81

Coggeshall, Mary .......... 87

Coit, Martha ............ 132

Colchester, Lord $\ldots \ldots \ldots \ldots . . .62$

Conversation, A .............31, 82

Cooke, Rebecca ........... 171

Cooper, Miss ...........84, 143

Cooper, D.D., Myles ........ 82

Cooper, Rev. Samuel ..... 83

Copeland, Ann ........... 58

Copley, Miss ..........35, 267

Copley, John Singleton .... .5, 35, 84

Copley, Mrs. J. S. . . . . 17, 85, 234

Copley, Richard........... 5

Copley, Susannah ......... 85

Cornwallis, Marquis .......... 85

Cotton, Madam ........... 86

Cranston, Rhoda $\ldots \ldots \ldots \ldots . .68$

Cranston, Thomas .......... 86

Cranston, Mrs. Thomas ..... 87

Crawford, Candace .......... 87

Crommelin, Mary ........... 246

Cummings, Mrs. Elizabeth ... 49

Cupid and Venus ......... 88

Dalton, Mrs. Peter Roe .... . . 88

Dana, Rev. Edmund......... 89

Dana, Richard ............ 89

Danforth, Judge ............ 90

Davis, Mrs. Anstice ....... 90

Dawes, Mrs. Mehitable ...... 91

Dawes, Judge Thomas ....... 91

Deas, Mrs. and Children ...... 92

Death of Major Pierson .10, 16, 35

DeBlois, Gilbert............ 93

De La Motte, Major-General 34,94

De Lancey, Mrs. Elizabeth ... 94

Delisle, Mrs. Lanfrey ........ 94

De Mountfort, Dr. . . . . . . 95

Dennie, Miss Eunice ........ 71

Derby, Mrs. Richard ...... 95

Devereux, Mrs. ........... 95

Dorchester, Lord ......... 179

Douglas, John $\ldots \ldots \ldots \ldots \ldots .96$

Dowse, Relief .............. 117

Duane, Mrs. James ........ 97

Duane, Judge ............ 96

Duchenhausen, Colonel …34,97 
PAGE

Duckett, Sir George . . . . . . 97

Dudley, Lady ............ 97

Dudley, Lady and Ward ..... 32

Dudley, Viscount........... 97

Dudley, Viscount and Ward .32, 33

Dumaresq, James ........ 98

Dumaresq, Rebecca ........ 98

Dummer, Anna ........... 199

Duncan, Viscount . . . 32, 34, 73, 99

Dundas, Robert .......... 99

Dunkirk, Taking of ....... 237

Edwards, Mary ........... 236

Eliot, Josiah ............ 99

Eliott, George Augustus ..... 140

Ellery, Mrs. Nathaniel ...... 99

Erskine, Mrs. David ........ 100

Erving, James ........... 100

Erving, Hon. John ......... 101

Evans, Captain John ...... 101

Everett, Dr. Moses ....... 267

Family Picture .....10,35, 79, 101

Fauconberg, Lord ......... 103

Fayerweather, Hannah..... . 259

Fayerweather, Dr. Samuel ‥ 103

Fenno, Mr. ........... 27

Fitch, Colonel, and Sisters .32, 104

Fitch, Hannah ........... 52

Fitch, Timothy .......... 104

Fitch, Mrs. Timothy........ 105

Fleet, Thomas ........... 105

Flucker, James ............ 106

Flucker, Thomas ........27, 106

Folger, Timothy ......... 107

Fort, Mrs. Seymour . . . . . 108

Forbes, Mrs. Dorothy . . . . . 107

Foster, Eleanor ........... 108

Foster, Captain Isaac . . . . . 108

Foster, Mrs. Isaac . . . . . . . 109

Foster, Dr. Isaac, Jr. . . . . . 109

Foster, Dr. William......... 109

Fowle, Colonel .......... 109

Francis, Anne .......... 267

Franklin, Governor ........ 109

Frothingham, Esther ...... 196

Gage, Mrs. Thomas . . .21, 24, 111

Gage, General Thomas ..... 110

Gallatea................. 110

Gambier, Admiral .......... 267

Gardener, The Little. . . . . . . . 112

Gardiner, Anne ........ 69
Gardiner, John ...........

Gardiner, Dr. Sylvester . . . . . 112

Gardiner, Mrs. Sylvester . . . . 113

George III. . ..........16, 113

George III. and his Queen .... 113

George IV. .............. 114

Gerrish, Benjamin ........ 114

Gerrish, Joseph .......... 115

Gerrish, Sarah ........... 55

Gibbons, Ann .......... 113

Gibbs, Margaret $\ldots \ldots \ldots \ldots .45$

Gibraltar, Siege of $\ldots \ldots \ldots 16,34,36$

Gill, Mrs. Michael ......... 117

Gill, Governor Moses ........ 115

Gill, Mrs. Moses ......... 116

Gill, Mrs. Sarah Prince ........ 118

Glover, Colonel Jonathan .... 120

Glover, Mrs. Jonathan ...... 120

Goldthwait, Miss ......... 49

Goldthwait, Mr. .......... 27

Goldthwait, Ezekiel ......... 120

Goldthwait, Mrs. Ezekiel .... 121

Goldthwait, Major Joseph .... 121

Goldthwait, Major Thomas .. 112

Gorham, Elizabeth ........ 209

Gorham, Mercy ........... 60

Gore, Catherine........... 239

Gore Children ............ 121

Grafton, Joshua .......... 122

Graham, J. A. ..........32, 122

Graham, Sir Robert ....... 122

Granger, Mrs. Gideon........ 123

Grant, Janet ............ 201

Graves, Katherine ........ 212

Gray, Mrs. ..........123, 190

Gray, Elizabeth ......... 190

Gray, Harrison. . . . . . . . . 123

Gray, John ............ 123

Gray, Mrs. John .......... 190

Greaton, General .......... 124

Green, Jonathan $\ldots \ldots \ldots \ldots .27$

Green, Joseph............... 124

Green, Councillor Joseph .... 124

Green, Mrs. Joseph ........ 125

Greene, Benjamin .......... 126

Greene, Catherine ......... 130

Greene, Lieutenant Francis .127

Greene, Gardiner ...... 127, 128

Greene, Mrs. Gardiner . . . . . . 128

Greene, John ........... 129

Greene, Mrs. John. . . . . . . . . 129

Greene, Joseph ........... 130 


\section{PAGE}

Greene, Mrs. Joseph . ...... 130

Greene, Rufus ............ 131

Greene, Mrs. Rufus ...... 131

Greene, Thomas........... 131

Greene, Mrs. Thomas ...... 132

Greene, Thomas and Wife ... 133

Greenleaf, Rev. Daniel ..... 133

Greenleaf, Hannah ........ 46

Greenwood, Mrs. Samuel .... 134

Gretton, William ......... 134

Griggs, Susanna ......... 88

Hagar and Ishmael . . . . . . 32, 135 Haldimand, General Frederick 135 Hall, Miss . ........... 136

Hall, Hugh . . . . . . . . . 135

Hallowell, Benjamin . . . . . . 136

Hancock, John ........27, 136

Hancock, Mrs. John . . . . . . . 220

Hancock, Thomas .......... 138

Hancock, Mrs. Lydia ........ 139

Harris, Mary ............ 147

Hastings, Warren .......... 272

Hay, Mrs. John . . . . . . . . 139

Hayley, William ........... 140

Heathfield, Lord . . . . . . 34, 140

Heber, Richard ......... 140

Henchman, Daniel .......... 141

Henshaw, Joseph .......... 141

Henshaw, Mrs. Joseph . . . . . . 142

Henshaw, Joshua .......... 141

Henshaw, Sarah .......... 142

Hill, Miss ............. 268

Hill, Mr. and Mrs. ........ 143

Hill, Hannah $\ldots \ldots \ldots \ldots \ldots . .204$

Hill, Henry ........... 142

Hill, Mrs. Henry .......... 143

Hixon, Joseph Sayer ........ 143

Hixon, Mrs. Joseph Sayer ... . 143

Hollis, Thomas............ 144

Holmes, Mrs. Isaac . . . . . . . 144

Holmes, John B. .......... 145

Holmes, William ........... 145

Holy Family ........... 145

Holyoke, Edward ......... 145

Hooper, Miss .......... 126

Hooper, Alice ............ 146

Hooper, Joseph .......... 146

Hooper, Mrs. Joseph. . . . . . 147

Hooper, Robert ........... 147

Hooper, Mrs. Robert . . . . . 148

Hooper, Robert, Jr......... 148
PAGE

Hooper, Mrs. Stephen . . . . 148

Howard, Judge Martin ....... 149

Howe, Lord ...........34, 149

Howe, Richard, Earl ........ 149

Hubbard, Daniel ............ 150

Hubbard, Mrs. Daniel ........ 150

Hubbard, Thankful ........ 150

Hubbard, Thomas ......... 151

Hugo, Colonel ............34, 151

Hull, General William ....... 13

Hunter, Miss Eliza ........... 151

Hurd, Nathaniel $\ldots . \ldots \ldots \ldots .151$

Hust, Mr. ................ 22

Hutchinson, Thomas......... 152

Hutchinson, Mrs. Thomas ‥ 154

Hyatt, General........... 154

Inches, Mrs. Henderson . . . . 154

Ingersoll, Jared $\ldots \ldots \ldots \ldots \ldots 155$

Inman, Mrs. Ralph ............. 155

Izard, Mr. and Mrs. Ralph ... 156

Jackson, Jonathan ........ 156

Jackson, Mrs. Jonathan ...... 158

Jackson, Joseph ............ 158

Jackson, Rev. Joseph . . . . . . 158

Jaffrey, George............ 159

Jaffrey, Mrs. George ........ 159

Jenkins, Mrs. Louis. . . . . . . . . 126

Jerome, St. . . . . . . . . . 235

Jephson, Mrs................ 159

Johnston, Miss ............ 21

Johnstone, Benjamin ......... 160

Jones, William ............... 160

Joy, Benjamin ............ 13

Kemble, Captain ....... 19, 21

Kemp, Mr. ............ 22

Kent, Mrs. Ebenezer, Jr. ..... 47

Kilby, Miriam ............ 77

Knatchbull, Sir Edw.'s Family. 160

Langdon, Judge Woodbury ... 161

Langdon, Mrs. Woodbury .... 162

Laurens, Henry .............. 162

Lee, Colonel Jeremiah ......... 163

Lee, Mrs. Jeremiah ......... 164

Leigh, Judge Peter .......... 163

Lemmon, Dr. Joseph ......... 163

Leonard, Daniel ............ 165

Lewis, Thomas ............... 165

Liotard, Jean Etienne ......... 165

Littleton, Lord and Family ... 166 


\section{Page}

Livermore, Mrs. Judge . . ... 166

Livingston, Mrs. John ..... 167

Lloyd, Mrs. . . . . . . . . 167

Loring, Mr.............. 27

Loring, Hannah . . . . . . . 167

Lovers, The $\ldots \ldots \ldots \ldots \ldots .168$

Lowell, Judge John ........ 168

Lyde, Captain ............ 168

Lynde, Lydia . . . . . . . . . . . . . 249

Lyndhurst, Baron ........14, 169

MacDonald, Flora ......... 173

Mackintosh, Mr.......... 211

Mackintosh, Mrs. ............ 211

MacPheadris, Mrs. Archibald . 173

MacPheadris, Mary ....... 249

Mallet, J. ............. 22

Mann, Thomas ........... 170

Mann, Mrs. Thomas ........ 170

Mansfield, Lord .......31, 35, 171

Marchant, Judge Henry .... 171

Marchant, Mrs. Henry ..... 171

Marsh, Lord ............. 57

Marshall, Colonel Thomas ... 172

Marshall, Mrs. Thomas ..... 172

Marston, Judge Nymphus ... 174

Mars, Venus and Vulcan ... 6, 172

Martin, Mrs. ........... 27

Marryat, Mrs. ............. 174

Mason, Jonathan, Jr. . . . . 13, 15

Maturin, Captain .......... 22

May, Colonel Joseph ........ 175

May, Mehitable .......... 91

Mayhew, Rev. Jonathan .... 175

Mayhew, Mrs. Jonathan .... 175

McEvers, Mrs. ......... 22, 25

McEvers, Gulian ......... 246

McWhorter, Alexander ....49, 176

McWhorter, Mrs. Alexander 49, 176

Merchant, William ........ 176

Mifflin, Thomas, and Wife... 177

Miller, William Shearer ..... 177

Moffat, Catherine ........... 265

Monmouth before James II.. 34, 178

Montague, Mrs., and Robert

Copley.............33, 179

Montague, Mrs. Mary Elizabeth178

Montesque, Mrs. Monte ..... 179

Montgomery, Major ......31, 179

Montressor, Captain ....... 22

Montressor, Mrs. ........ 22

Moore, Sir John .......... 180
PAGE

Morris, Mrs. .......... 22

Mortier, Mrs. ............ 22

Mountfort, Sir Jonathan ..... 180

Murray, Mrs. ............ 128

Murray, Elizabeth.......... 155

Murray, Hon. James......... 181

Murray, Colonel John ....... 181

Murray, Mrs. John ......... 182

Murray, Rev. John .......... 183

Murray, Mrs. John ........ 183

Murray, William .......... 171

Nativity, The .....10, 31, 34, 183

Negro, Head of . ....... 34, 184

Nelson, Lord ............ 184

Neptune ............... 184

Newton, John............ 185

North, Lord . . . . . . . . . . . 185

North, Lady ............. 185

Northampton, Earl of ....... 32

Northampton, Lord, and Son . 186

Nun with Candle ......... 186

Offer of Crown to Jane Grey

$33,35,186$

Ogilvie, Rev. Mr. ........21, 187

Oliver................ 189

Oliver, Lieut.-Gov. Andrew . . 187

Oliver, Andrew, Jr. . . . . . . . . . 187

Oliver, Daniel............. 188

Oliver, Elizabeth . . . . . . . . 256

Oliver, Griselda ........... 248

Oliver, Chief-Justice Peter ... 188

Orange, Prince of.......... 57

Osborne, Catharine ........ 216

Osborne, Mary .......... 256

Osborne, Sarah........... 257

Otis, Harrison Gray $\ldots \ldots \ldots 13,15$

Otis, Colonel James.......... 189

Otis, Mrs. James ........... 189

Otis, Mary ................. 190

Otis, Mercy ............. 251

Otis, Mrs. Samuel Allyne .... 190

Parsons, Rev. Jonathan ...... 191

Paxtell, Mrs. William ........ 191

Peale, Charles Wilson ....... 7

Pelham, Charles..........5, 192

Pelham Children ............. 193

Pelham, Henry. . . 12, 23, 24, 25, 192

Pelham, Peter ...........5, 193

Pelham, William ........... 5

Pepperell, Mr. .......... 27 
PAGE

Pepperell, Lady . . . . . . . . . 194

Pepperell, Elizabeth . . . . . . . 231

Pepperell Family . . . . . . . . 194

Pepperell, Sir William.....194, 195

Pepperell, William and Sister . 195

Perkins, Mrs. Edmund . . .... 196

Phillips, Mary Winthrop ..... 196

Pickman, Colonel Benjamin . 197

Pickman, Mrs. Benjamin .... 197

Picton, Sir Thomas ........ 198

Pierce, Anna .......... 52

Pierpont ............. 198

Pierson, Major ........... 191

Pierson, Death of Major ... 92

Pitt, William ........... 199

Ponsonby, William ........ 199

Powell, John ........... 201

Powell, Mrs. John ........ 201

Powell, Mrs. John ........ 199

Princesses, Three .......... 202

Quincy, Dorothy .......... 220

Quincy, Josiah ............ 202

Quincy, Samuel ............. 204

Quincy, Mrs. Samuel ..... 204

Randolph, Susanne ......... 205

Rea, Mrs. Daniel and Daughter 205

Red Cross Knight . . . . . 32, 35, 205

Resurrection, The .....17, 33, 206

Revere, Paul........... 206

Richards, Captain ........ 25

Richards, Charles Lloyd. . . . . 207

Richards, Mrs. Eliza Willing . 207

Richards, John ........... 207

Richards, Mary ........... 243

Richards, R. ...........32, 208

Rodney, Lord . . . . . . . . 208

Rogers, Mr. ........... 208

Rogers, Mrs. Daniel . . . . . . . 209

Rogers, John ........... 210

Rogers, Mrs. Timothy . . . . . 210

Ronchon, Mary .......... 225

Ross, Elizabeth . . . . . . . 244

Royal Academy ........... 33

Royall, Isaac $\ldots \ldots \ldots \ldots .211$

Royall, Mrs. Isaac......... 211

Royall, Polly ........... 211

Russell, Judge Chambers .... 211

Russell, Mrs. James ...... 212

Safford, Margaret .......... 154

St. Cecilia ..........33, 95, 234
PAGE

St. Clair, Sir John ........ 234

St. Jerome.............. 35,235

Salisbury, Elizabeth ........ 56

Salisbury, Stephen........ 212

Saltonstall, Judge Richard. ... 212

Samuel and Eli ..........35, 213

Sargent, Mr. . . . . . . 27

Sargent, Ann .......... 99

Sargent, Mrs. Daniel ........ 218

Sargent, Colonel Epes, Sr. . . . 214

Sargent, Mrs. Epes, Sr. . . . 215

Sargent, Epes, Jr. .......... 215

Sargent, Mrs. Epes, Jr. . . . . . 216

Sargent, Juđith .......... 183

Saul reproved by Samuel ...32, 35

Savage, Samuel Phillips . . . . . 218

Savage, Mrs. Samuel ........ 219

Schleppengull, Colonel ....34, 151

Schilling, G. W. ......... 219

Scollay, John ............... 219

Scollay, Mrs. John ......... 220

Scott, Dorothy Quincy ..... 220

Scott, Governor George . . . . . 221

Scott, Mrs. George .......... 222

Scott, James ............... 222

Scott, Colonel Olney ....... 222

Scott, Mrs. Olney ......... 222

Sears, David ............. 223

Sewall, Dr. Joseph . . . . . . . . 223

Sheafe, Sir Roger ......... 223

Sherbrook, Mr. ......... 22

Sherburne, Mary ............. 63

Sherburne, Mrs. Samuel .... 250

Sidmouth, Lord . . . . . . . . . 33, 224

Siege of Gibraltar ......... 225

Sigourney, Andrew ......... 225

Sigourney, Mrs. Andrew . . . . 226

Singleton, Mary ......... 5

Sitwell Family .............. 226

Skinner, Mrs. ...........36, 226

Small, Captain John ...... 227

Smelt, Ann Tyng .......... 228

Smith, Mrs. . .......... 228

Smith, Isaac …......... 229

Smith, Mrs. Isaac . . . . . . . 228

Smith, Mrs. W. S. . . . . . . 230

Smith, Rev. William ....... 229

Smybert ............. 6

Society of Artists of Great

Britain ........... 7,33

Sparhawk, John ...........230

Sparhawk, Colonel Nathaniel . 230 
PAGE

Sparhawk, Mrs. Nathaniel.... 231

Spencer, Earl ..........32, 232

Spooner, Mrs. George ...... 232

Spooner, William ......... 233

Startin, Mrs. Charles . . . . . 36, 233

Stevens, Mrs. Robert . . . . . . 234

Stevens, Mrs. William . . . . 234

Stillman, Rev. Mr. ......... 235

Stillman, Mrs. ........... 235

Storer, Ebenezer $\ldots . \ldots \ldots \ldots .235$

Storer, Elizabeth ......... 228

Storer, Mary ............ 235

Storer, Mrs. Mary ......... 236

Surrender of DeWindt . ..... 236

Surrender of Five Members .. 76

Swan, James ........... 13

Sweet, Martha .......... 164

Tapestry Design $\ldots \ldots \ldots \ldots 237$

Taylor, Jeremiah $\ldots \ldots \ldots \ldots .237$

Temple, Lady............. 238

Temple, Sir John ......... 238

Thacher, Oxenbridge........ 239

Thacher, Mrs. Oxenbridge ... 239

Todd, Samuel ............. 239

Torrey, Mrs. Samuel......... 239

Tracy, Hannah .......... 158

Traille, Captain Peter....... 140

Traille, Robert .......... 240

Treadwell, Madam .......... 241

Trumbull, John ......... 7

Tufts, Ruth ........... 247

Turner, Eunice........... 50

Turner, Captain William ..... 241

Turner, Mary .............. 218

Turner, Mrs. William . . . . 242

Tyler, Mrs. Andrew ....... 243

Tyler, John Tyng $\ldots . . \ldots .243$

Tyler, Sarah .......... 218

Tyng, Eleazer. . . . . . . . . . . 244

Tyng, Colonel William ...... 245

Tyng, Mrs. William ...... 244

Unknown Portraits . . . . . . . 269

Vans, William .......... 245

Vans, Mrs. William ........ 245

Vawdrey, Thomas William .. 245

Venus and Cupid ........ 10,34

Verplanck, Daniel C. ....... 246

Verplanck, Mrs. Gulian ...... 246

Verplanck, Samuel .......... 247

Vinal, Mrs. Judge ......... 247
PAgE

Vose, Mrs. Elijah ........ 247

Wait, Daniel. . . . . . . . . . . 248

Waldo, Mrs. Samuel ....... 248

Wales, H. R. H. The Prince of 33,35

Walter, Mrs. William ........ 249

Warner, Mrs. Jonathan ..... 249

Warner, Mary .............. 250

Warren, General James ..... 250

Warren, Mrs. James ......... 251

Warren, General Joseph .... 252

Warren, Mrs. Joseph ....... 253

Warren, Winslow ........... 253

Washington, George ........ 6

Watson, Brooke .......253, 254

Watson, Elkanah ......... 254

Watson, Colonel George ..... 255

Watson, Mrs. George ......... 256

Watson and the Shark ...... 253

Watts, Mrs. ............. 27

Watts, Mary $\ldots \ldots \ldots \ldots .256$

Watts, Mrs. Samuel . . . . . . 257

Webb, Joseph ........... 257

Wellington, Duke of ....... 57

Welsteed, William .......5, 6, 261

Wentworth, Frances Deering . 262

Wentworth, Hannah ....... 47

Wentworth, Sir John ....... 261

Wentworth, Mr. and Mrs.

Joshua .............. 263

Wentworth, Sarah ......... 173

West, Benjamin ........ 7, 9, 10

Western Family .......... 262

Western, Lord and Brother .. 262

Whipple, Mrs. Oliver . . . . . . 265

Whipple, Mrs. William ..... 265

Whitworth, Dr. John ....... 266

Wibird, Hon. Richard........ 266

Wignall, Anstice Elizabeth ... 234

Wilkes, John . . . . . . . . . 51

Wilson, R.............. 32,258

Winslow, Anna Green ...... 266

Winslow, Joshua .......... 258

Winslow, Mrs. Joshua ....... 167

Winthrop, Prof. John . . . . . 258

Winthrop, Mrs. John ....... 259

Winthrop, Lucy ........... 159

Winthrop, Samuel ......... 260

Woodbridge, Sarah ......... 148

York, Duke of ........... 98

Youth rescued from Shark

$17,31,34,36$ 


\section{Owners' Index}

PAGE

Abbott, Mrs. Gordon . . . . 104, 262

Aberdare, Lord . . . . . . . . . 76, 93

Adams, Miss ............... 121

Adams, Charles F.......... 230

Allen, Zachariah .......... 88

Alline, Mrs. Louisa ......... 121

Almon, Dr. Bruce ......... 72

Amory, Copley ......76, 102, 244

Amory, Frederic . . . . 102, 193, 247

Amory, Harcourt . . . . . . .84, 85

Amory, Ingersoll . . . . .44, 102, 155

Andrews, Rev. George B..... . 45

Appleton, Marjorie, Estate of 66, 95

Apthorp, Miss Ann ........ 45

Apthorp, R. E........... 46

Armstrong, D. Maitland ... 92

Bates, Edward C. .......... 96

Barnard, Mrs. G. M. . . ..... 168

Barrell, Henry F........... 52

Barrett, Mrs. Samuel E. . . . 115

Barrett, Mrs. Sarah, Estate of $55,56,115,143$

Baury, Miss ........... 135

Beale, The Misses ......... 58

Beebe Family . . . . . . . . 114

Bigelow, W. Sturgis . . . . . . 220

Black, George N. .....60, 89, 215

Boston, City of $\ldots \ldots \ldots 40,137$

Boston Museum of Fine Arts 79,85 , $110,124,156,227,252,253,271$

Boston Public Library . . . . . . 76

Bowdoin College .......... 106

Bowen, Henry . . . . . . . . . 62

Bowen, Dr. J. T. $\quad \ldots \ldots \ldots 113,120$

Bowen, Mrs. S., Estate of ... 221

Bowler, Mrs. Robert . . . . . 64

Brandagee, Mrs. E. D. . . . . 205

Brewster, Mrs. William . . . . . 248

Brook, The ............ 221

Brooks, Edward .......... 76

Brooks, Peter C. ......... 86

Brown, Mrs. Atherton . . . . . 158

Brown, Mrs. Lathrop . . . . . . 147

Buckingham Palace......... 202
PAGe

Buffum, Mrs. David ....... 109

Bulfinch, Mrs. S. G. ......... 90

Burguyn, Colonel H. R. .... 70

Burke, Mrs. Harold ........ 167

Burroughs, Mrs. Charles .... 69

Cabot, Mary E. ......... 57

Carter, W. Smith.228, 229, 235, 236

Cary, Miss E. F. . . . . . . . 75

Chapman, Mrs. H. B....... 172

Chapman, Mary G.......... 133

Clarke, Thomas B. ........136, 238

Clements, Mrs. G. H. 215, 216, 217

Cobb, Francis S. .......... 140

Cochran, Alexander Smith ... 163

Codman, Bishop ......... 80

Codman, Charles R. ........ 212

Codman, James M. .......100, 265

Codman, Miss Martha .......43

Codman, Miss M. C. ...... 79

Codman, Miss M. P. . . . . . . 44

Codman, Richard ........ 81

Colt, Miss Fannie E. ........ 49

Columbia University ......... 186

Coolidge, Mrs. T. J., Jr. . . . . 154

Crane, Mrs. George F. . . . 187, 188

Crocker, Miss Sarah ......... 120

Currier, Miss Sarah......... 126

Cunningham, Miss Hester ... 74

Curtis, Charles P. . . . . . . . . . 192

Curtis, Henry P. . . . . . . . . 193

Cutter, Ralph............. 241

Cutts, Hampden . . . . . . 146, 232

Dalton, H. R., Estate of .... 212

Dana, Richard .......... 90

Danforth, Miss Mary ....... 63

Davis, Alba …......239, 267

Davis, Charles H. ......... 60

Dexter, Miss.............. 46

Dexter, Mrs. F. Gordon 47, 57, 76,

$84,85,88,94,97,114,122,151,154$,

$186,193,225,269$

Dexter, Gordon ............ 206

Dorr, George B. ............ 39 
PAGE

Duane, Dr. Alexander ....... 97 DuCane, Lady ..........170, 267

Eaton, Miss G. G. . . . . . . 236

Eliot, John F............ 106

Ellis, Mrs. . . . . . . . . . 249

Ellis, Roland ............ 270

Erving, Mrs. E. S. . . . . . . 271

Erving, J. Langdon .......101, 222

Essex Institute ........... 105

Everett, Sidney .......... 143

Farlean, Mrs. C. D. . . . . . 95

Fenno, Edward N. ........ 50

Forbes, Mr. J. M. .......130, 131

Forbes, Miss Sarah ........ 108

Ford, James H. . . . . . . . 166

French, W. M. R., Estate of .. 177

Fuller, Lawrence S. ......... 196

Furness, Nathaniel ........ 152

Gardiner, Mrs. C. P. . . . . . . 112

Gardiner, Robert H. . . . . 69, 113

Gay, Dr. F. L. .......... 72

Goddard, George A. ........ 43

Goldsborough, Colonel F. C. .267

Greene, Francis Matthews . . 127

Greene, Henry Copley ...... . 84

Greene, Mary Amory ....... 102

Greenleaf, R. C........... 134

Greenwich Hospital........ . 59

Greenwood, Isaac, Jr. . . . . . 134

Greenwood, John D. ........ 134

Guildhall, London ${ }^{\prime . . . . . . . . . ~} 86$

Hall, Dudley ............ 271

Hammond, Mrs. G. G. ..... 84

Hanks, Mrs. Charles S. . . . 160

Harlow, Miss Mabel ....228, 245

Harriman, Mrs. E. H. . . . 179, 250

Harris, Edward D. . . . . 104, 260

Harvard College $38,40,45,65,83$, $138,144,146,151,235,260$

Haskins, David Greene . ...132, 133

Hayden, Mr. . . . . . . . . . . . . 75

Hayđen, H. J. ........... 86

Hayes, John L. . . . . . . . . 172

Hayward, Sidney W. ......141, 142

Hazen, J. Douglas . . . . . . . 182

Heard, Mrs. John ............. 228

Heffinger, Dr. Arthur . . . . . . 240

Hewlett, J. A............ 269
PAGE

Hidden, W. U. . . . . . . . . 87

Hixon, Miss Julia P. . . .....143, 235

Holland, A. N. . . . . . . . . . 91

Holmes, Oliver W..........83, 157

Homans, Mrs. Robert. . . . . . 39

Hooper, Samuel . . . . . . . . 147

Howe, Henry M. . . . . . . . . 129

Howe, J. Murray ......... 181

Hull, Miss .............. 99

Hutchings, William V. . . . . 199

Inches, Mrs. John Chester . . 154

Jackson, Mrs. James . . . . 157, 158

Jackson, Susan Cabot . . . . . 157

Jarvis, Aemilius . . . . . . . 166, 201

Jeffries, William A. ........ 159

Johnson, Lewis........... 165

Joy, Mrs. C. H. ......... 54

Kent, Prentiss .......... 48

Kimball, Mrs. David P...... 65

King, Mrs. Robert ......... 146

Knapp, Mrs. H. S. . ....... 71

Knight, Mrs. M. ........ 94

Langarbach, Mrs. ........ 98

Langdon, Woodbury .......161, 162

Lathrop, Judge, Estate of . . . . 270

Lee, Thomas Amory ....... 164

Lee, Mrs. T. J. . . . . . . . . . . 257

Lewis, George R. .......... 208

Liechtenstein Gallery ......... 74

Longfellow House . . . . . . . . . 195

Loring, F. C. ............ 200

Loring, Mrs. Henry. . . . . . . . 224

Loring, William C. ....... 168

Low, Miss Louisa ......... 210

Lyde, Maria ............. 168

Marchant, F. E. ........... 171

Marston, George ........... 174

Mass. Historical Society $41,44,83$,

$153,210,261$

Metcalf, John G. ........170, 171

Metropolitan Art Museum

$212,229,235$

Miller, Charles E. ........... 73

Minot, J. Grafton ......... 122

Morse, Miss F. R. . . . . . . . 240

Moseley, F. S. . . . . . . . . . 257

Munn, Mr. ............. 107 
PAGE

National Museum .......... 101

National Portrait Gallery ..... 232

Newbury Historical Society... 183

New England Genealogical Soc. 243

New Hampshire State House . . 262

Newport Historical Society . . . 234

Newton, Mrs. E. A. . . . . . . 185

Newton, Mrs. J. L. ......... 146

N. Y. Historical Society $84,167,191$

New York Public Library. 148, 263

Nightingale, Louisa, Estate of

117,210

Old Colony Historical Society . . 165

Oliver, Mrs. F. . . ........ 188

Otis, Harrison Gray ...123, 189, 190

Otis, Mrs. Harrison Gray .... 59

Paine, R. T., 2d. . . . . . . . . . 202

Parker, Mrs. C. H. ......... 93

Parker, W. Prentiss. . . . . . . . 220

Parsons, H. E. . . . . . . . . . . 191

Peabody, Miss ............ 265

Peck, Mrs. Philip . . . . . . . . 109

Penhallow, Mr. ......... 266

Penn. Historical Society . . 177, 234

Popham, Louis .......... 47

Porter, Mrs. A. S. . . . . . . . 269

Pratt, Mrs. F. A. .......... 175

Pratt, Mrs. H. E. . . . . . . 145

Pratt, Robert M. .....67, 68, 118

Pray, Mrs. A. A. . . . . . . . . 66

Prescott, William G. . . . . . 131

Prouty, Dwight M. . . . . . . 145

Prouty, Mrs. Dwight M. . . . 126

Pulitzer, Mr. ........... 254

Putnam, Mrs. William Allen 53, 145

Reinhardt, Henry . . . . . . . 246

Revere, Mrs. John. . . . . . . . 207

R. I. School of Design .116, 117, 119

Rindge, F. R., Estate of..... . 231

Robins, The Misses . . . . . . . 121

Robins, Edward B. . . . . . . 122

Rogers, The Misses ........ 123

Rogers, Miss A. P. .....200, 209

Rogers, Mrs. N. M. ....... 100

Rogers, Mrs. R. P. . . . . . 156

Ross, Mrs. ............ 226

Russell, Mrs. Edward ....... 234

Saltonstall, R. M. ......... 213

Sanborn, Miss N. M. ....... 180
PAGE

Sargent, Charles S. .......42, 183

Savage, John R............ 219

Searing, Mrs. P. J. L. . . . . . 247

Shaw, Samuel Savage...$\ldots .219$

Sherburne, Miss E. .......174, 249

Simpson, Miss . ........184, 232

Sitwell, Sir George.......... 226

Sligo, Marquis of ........ 70

Smith, F. B. ............. 269

Smith, Mrs. Mary W......... 194

Snow, Miss H. Elizabeth . . 125, 270

Snow, Mrs. William C. . .... 64

Social Law Library ......... 149

Sohier, W. D. ........... 82

Spooner, Dr. L. H. . . . . . . 233

Stevenson, R. H. .......... 148

Swett, Colonel Samuel ...... 61

Tappan, Winthrop ......238, 239

Tasker, Lyman H.......... 76

Taylor, Mrs. Martin ........83,84

Temple, Edward ......... 56

Thayer, Adele G. ........... 123

Theological Library. . . . . . . . 69

Thompson, Mrs. ......... 255

Thompson, Mrs. H. C. . . ... 205

Thorne, Robert H. ........ 180

Tilton, Mrs. J. W. . . 137, 138, 139

Todd, Mrs. ........... 142

Treadwell, Miss Grace ...... 204

Trinity Church ............. 187

Trott, Miss E. C. ......... 266

Tudor, Mrs. ............. 150

Turner, Samuel F. . . ....242, 243

Uniac, Mrs. F. . ......... 109

Updike, D. Berkeley ....... 87

Upham, Mrs. Charles …... 157

Vans, Miss ............. 245

Vaughan, Mrs. W. M. ..... 136

Verplanck, Samuel ......... 247

Verplanck, W. E............. 246

Vose, R. C. and N. M. ...130, 268

Wadsworth Athenaeum ..... 108

Wadsworth, Mrs. W. Austin

$99,233,272$

Wainwright, Mrs.......... 237

Walcott, Robert. . . . . . . . . 249

Ware, Mrs. John ........... 183

Warren, Dr. John C.......... 252 


\begin{tabular}{|c|c|}
\hline PAGE & PAGE \\
\hline Warren, Pelham W. & White, J. D. W. \\
\hline Warren, Winslow .. & Whitwell, F. S.. \\
\hline Weld, Fred C. ... & Williams, John S. \\
\hline Welles, Miss Jane & Wilson, Martha D. \\
\hline Wentworth, Susan & Winslow, George S. .. \\
\hline Western, Mrs. D. C. & Winthrop, Mrs. R. C. \\
\hline Wetmore, Senator... & Wood, Mrs. C. H. ... \\
\hline Wharton, Miss N. C. & Woodruff, Mrs. A. .... \\
\hline Wheeler, Everett P. . . . . 194, 195 & Worcester Art Museum ... \\
\hline Wheelwright, Mrs. Andrew C. . 77 & Wyman, Morrill, Estate of.... \\
\hline $\begin{array}{l}\text { White, Frederick J. . . . . . . } 178 \\
\text { White, George R. . . . . . . . } 268\end{array}$ & Yale School of Fine Arts \\
\hline
\end{tabular}







$$
\text { * }
$$




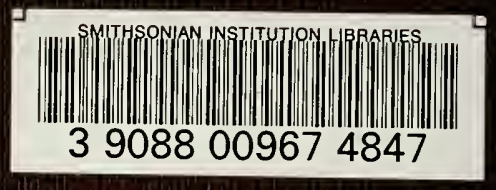

